\title{
PRODUÇÃO DE CELULASES E FUSÃO DE \\ PROTOPLASTOS EM HUMicola sp
}

\section{EDISON NEIROTTI ROUMAS}

Jiceraciado em viências Biolögicas

ORIENTADOR: Prof.Dr. Joäo Lücio de Azevedo

Tese arresentada à Escola Superior de Agricultura "Luiz de Queiroz", da Vuiversidade de São Paulo, para obtença do titulo de Doutor em Agronomia. Area de Concentração: Ge nética e Melhoramento de Plantas.

$\begin{array}{llllllllll} & \mathrm{I} & \mathrm{R} & \mathrm{A} & \mathrm{C} & \mathrm{I} & \mathrm{C} & \mathrm{A} & \mathrm{B} & \mathrm{A}\end{array}$

Estado de São Paulo - Brasil

Setembro de 1988 
NEIROTTI, Edison

Produção de celulases e fusão

de protoplastos em Humicola sp.

Piracicaba, 1988 .

Tese - ESALQ

Bibliografia

1.Protopiastos-Fusão 2. Humic으르

sp. 3. Celulases. I-Escola Su-

perior de Agricultura "Luiz de

Queiroz" "Piracicaba. 


\section{PRODUÇÃO DE CELULASES E FUSÃO DE \\ PROTOPLASTOS EM Humicola sp}

\section{EDISON NEIROTTI ROUMAS}

Aprovada em: 24.10 .1988

Comissão Julgadora:

Prof. Dr. João Lūcio de Azevedo

ESALQ/USP

Profa Dră Aline Aparecida Pizzirani-Kleiner ESALQ/USP

Prof. Dr. Roland Vencovsky ESALQ/USP

Dr. Rolf Alexandre Prade

FTI

Dr. Juan Luis Carrau

I B / UCS

$$
\begin{gathered}
\text { Prof. Dr. João Lūcio de Azevedo } \\
\text { Orientador }
\end{gathered}
$$




\section{A meus pais}

Edison e Cleria DEDICO 


\section{AGRADECIMENTOS}

Ao Prof. Dr. João Lúcio de Azevedo, pela orientação, dedicação e apoio brindados nestes anos de trabalho.

A Prof.Dra. Aline Aparecida Pizzirani-Kleiner pela sua dedicação e constante incentivo demonstrado.

Ao Prof. Dr. Roland Vencovsky do Departamento de Genética e Bel. Gabriel A. Sarriés do. CIAGRI, pelo valioso assesoramento nas análises estatisticas e processamento de dados.

Aos Professores do Curso de Doutoramento em "Genética e Melhoramento de Plantas" pelos ensinamentos e contribugão á minha formag̃ão profissional.

Ao Prof. Dr. Darcy Martins Da Silva, da ESALQ, por terme introduzido aos principios da técrica de eletrosusão.

Aos meus colegas do Setor de Genética de Microrganismos do Departamento de Genética da ESALQ/USP, pelo constan te incentivo de amigos; em especial á Bel. Vânia Apare cida vicente pela sua valiosa colaboraça nos trabalhos de dosagem enzimática.

Aos Funcionários do Departamento de Genética da ESALQ/USP, em especial aos do Setor Genética de Microrganismos Antonio Rocha Campos, Carlos Nolasco e Sandra Rocha, pelos incalculáveis serviços prestados.

Aos colegas Walter Norbis e Luis Anastasia, da Facultad de Humanidades y Ciencias de Montevideo, Uruguay pela sua colaboracão em alguns estudos estatisticos. 
Ao Conselho Nacional de Desenvolvimento Cientffico e Tecnológico (CNPq) pelo valioso auxilio financeiro concedido ao autor; á FINEP pelo financiamento do projeto "Melhoramento genético em fungos produtores de celulases através de técnicas genéticas clássicas e de fusão de protoplastos " (FINEP 4.4.84.0787.00) do qual o autor integrou a equipe de pesquisas; ao Departamento de Genética da ESALQ/USP pelos recursos oferecidós e á Facultad de Humanidades y Ciencias de Montevideo, Uruguay, pela oportunidade brindada para realizar este curso.

A todos os que de alguma forma colaboraram para a realização deste trabalho. 
LISTA DE FIGURAS ......................

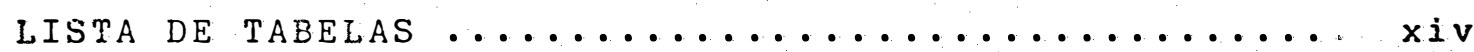

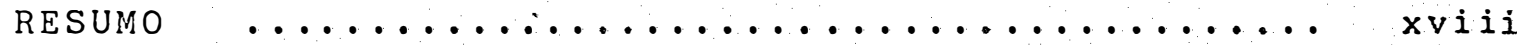

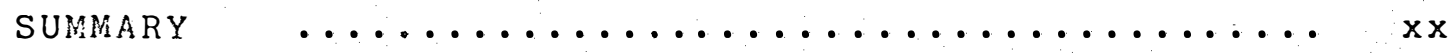

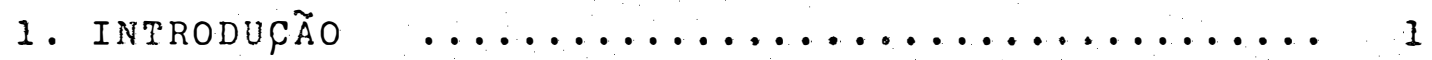

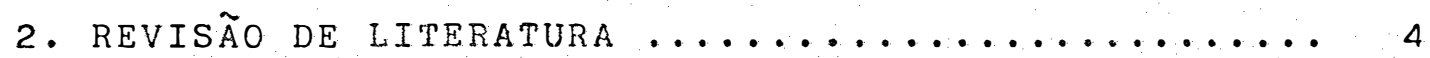

2.1. O Complexo Celulase. Biosintese e Regulação.. 4

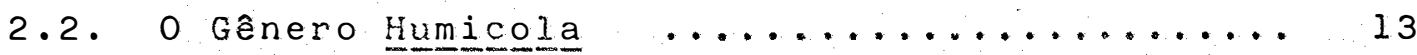

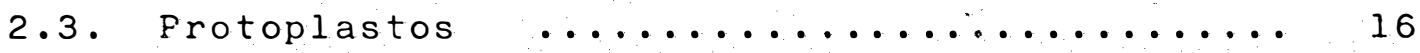

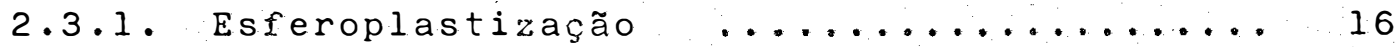

2.3.2. Fusão de Protoplastos $\ldots \ldots \ldots \ldots \ldots \ldots$

2.3.2.1. Fusão de protoplastos por tratamento

com Polietilenoglicol $\ldots \ldots \ldots \ldots$

2.3.2.2. Fusão de Protoplastos por Eletrofusão.. 21

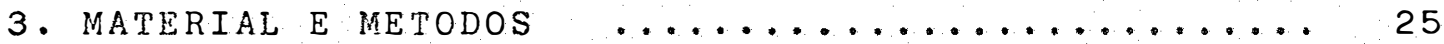

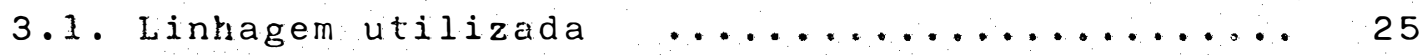

3.2. Meios de Cultura utilizados $\ldots \ldots \ldots \ldots \ldots$

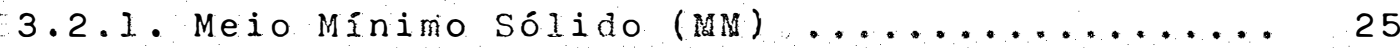

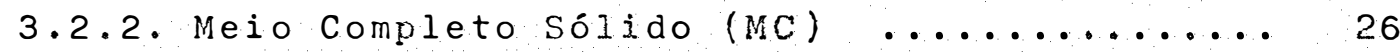

3.2.3. Meio Mínimo $2 x$ Concentrado $\ldots \ldots \ldots . . . .26$

3.2.4. Meio Completo 2 . Concentrado ......... 26

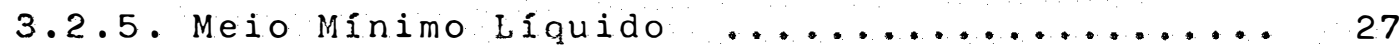

3.2.6. Meio para Crescimento de Micélio ........ 27

3.2.7. Meio Minimo para Humicoㅡㄹ sp (MMH) ....... 27

3.2.8. Meio para Regeneração de Protoplastos .... 27 
Página

3.2.9. Meio para visualização de halo de degradação de celulose 28

3.2.10. Meio de Petterson para Produção de Celulases 28

3.2.11. Meio E para Produção de Celulases ....... 29 3.2.12. Meio para nutantes Desreprimidos ........ 29

3.2.13. Meios com 2-Deoxiglicose ............ 30

3.3. Soluções utilizadas ........................... 30

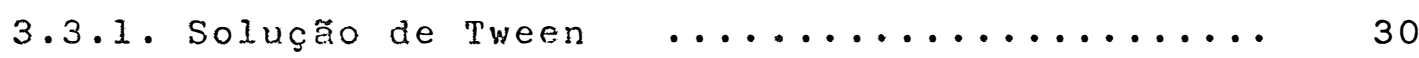

3.3 .2 . Solução Salina $(0,85 \%) \quad \ldots \ldots \ldots \ldots \ldots$

3.3 .3 . Solução de vitaminas $\ldots \ldots \ldots \ldots \ldots \ldots$

3.3 .4 . Solução de Ácidos Nucleicos de Levedura .. 31

3.3.5. Solução de Caseína Hidrolisada .......... 32

3.3.6. Solução de Extrato de Levedura ......... 32

3.3.7. Soluções de Aninoácidos para Caracterização de Mutantes Auxotróficos ................ 32

3.3 .8 . Solução de $\mathrm{NaOH}$ IN $\ldots \ldots \ldots \ldots \ldots \ldots \ldots \ldots \ldots$

3.3 .9 . Solução de $\mathrm{HCl}$ l $\mathrm{N} \ldots \ldots \ldots \ldots \ldots \ldots$

3.3.10. Tampão Fọfato $0,02 \mathrm{M} \mathrm{pH} 5,6 \ldots \ldots \ldots 3$

3.3.11. Tampão Fosfato $\mathrm{pH} 7,0 \ldots \ldots \ldots \ldots \ldots \ldots$

3.3.12. Tampão Citrato $0,05 \cdot \mathrm{M} \mathrm{pH} 4,8 \ldots \ldots \ldots . \ldots . \ldots$

3.3.13. Solução de Albûmina $5 \% \ldots \ldots \ldots \ldots$

.3.3.14. Solução Estoque de Giemsa ............ 35

3.3.15. Solução Corante de HCl Giemsa ......... 35

3.3.16. Soluções de Álcool Etilico ............ 36

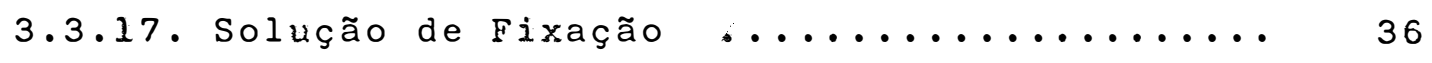

3.3.18. Reagente Áciodo Dinitro Saliçlico (DNS) . 36 
Página

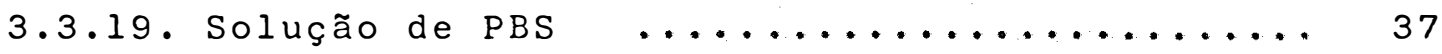

3.3.20. Solução Estoque de Tiamina .......................

3.3 .21 . Solução Estoque de Biotina $\ldots \ldots \ldots . \ldots . \ldots$

3.3.22. Soluções de 'fiamina e Biotina .......... 37

3.3.23. Solução de $\mathrm{MgSO}_{4} 0,5 \mathrm{M} \mathrm{pH} 5,6 \quad \ldots \ldots \ldots \ldots \ldots$

3.3.24. Solução de Sacarose $0,8 \mathrm{M} \mathrm{pH} 5,6$ e pH 7,0. 38

3.3.25. Solução de Sorbitol $0,8 \mathrm{M} \mathrm{pH} 7,0 \ldots \ldots 38$

3.3 .26 . Solução de Sorbitol $1,2 \mathrm{M} \mathrm{pH} 7,0 \ldots \ldots . \ldots 39$

3.3.27. Solução de Sorbitol $0,8 \mathrm{M} \mathrm{pH} 7,0 \mathrm{com}$ PEG

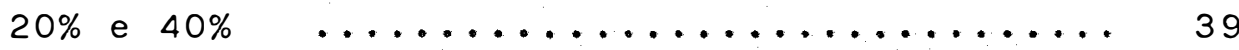

3.3 .28 . Solução de Benlate $\ldots \ldots \ldots \ldots . \ldots \ldots$

3.3 .29 . Solução de Acriflavina $\ldots \ldots \ldots . \ldots . \ldots . \ldots$

3.3.30. Solução de Cristal Violeta ............ 40

3.3.31. Tampão $\operatorname{Tr}$ is HCl $0,1 \mathrm{M}$ pH $8 \ldots \ldots \ldots . \ldots \ldots$

3.3 .32 . Vermelho Congo $0,025 \%$ pH $8 \ldots \ldots \ldots \ldots$

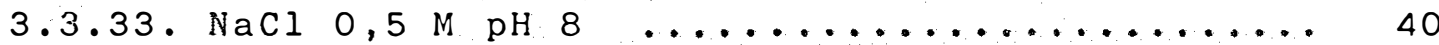

3.3.34. Esterilizaşão e Conservação ............ 40

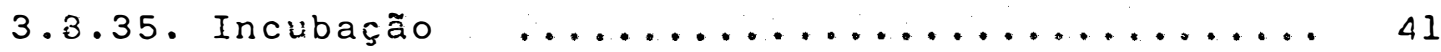

3.4. Técnica semiquantitativa de avaliação da produ-

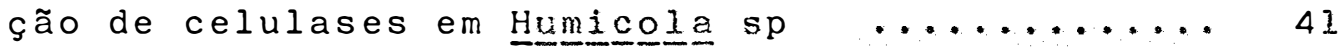

3.4.1. Meios de Cultivo ensaiados ............. 4 4

3.4.2. Condições de Cultivo: Inoculação, Incubação

e Choque térmico. .................. 42

3.4.3. Técnica de coloração $\ldots \ldots \ldots \ldots \ldots \ldots \ldots \ldots$

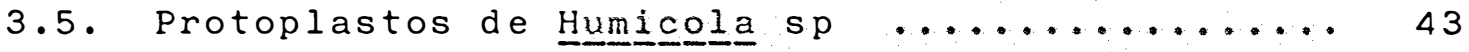

3.5 .1 . obtenção de protoplastos .............. 43

3.5.2. Regeneração de protoplastos ............ 44 
Página

3.5.3. Curva de Sobrevivência de protoplastos á

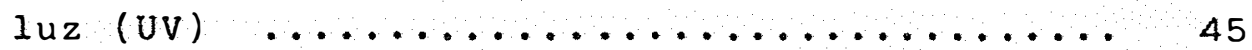

3.5.4. Técnica do Doador Morto ............. 45

3.5.5. Liberação de protoplastos a partir do micélio

3.5.5.1. Coloração de Conidios e Protoplastos .... 46

3.5.5.2. Frequêrucia do número de núcleos ...... 47

3.5.5.3. Diâmetro dos protoplastos .......... 47

3.6. Marcas Genéticas $\ldots \ldots \ldots \ldots \ldots \ldots \ldots . \ldots \ldots$

3.6 .1 . Obtenção de Mutantes ................ 48

3.6.1.1. Mutantes Morfológicos .............. 48

3.6.1.2. Mutantes Desreprimidos $\ldots . . . \ldots \ldots . . .49$

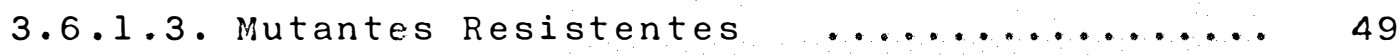

3.6.1.3.1. Resistência a Benlate .............4 49

3.6.1.3.2. Resistência a 2-Deoxiglicose ....... 50

3.6.1.3.3. Resitência a Corantes ............ 51

3.6.1.4. Mutantes Auxotróficos $\ldots \ldots \ldots \ldots \ldots \ldots$

3.7. Seleção de variantes para maior produção de

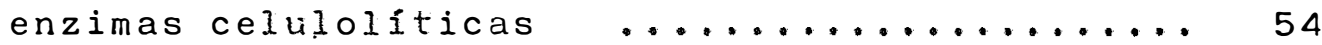

3.7.1. Seleção em placa ....................... 54

3.7.2. Dosgem enzimática $\ldots \ldots \ldots \ldots \ldots \ldots$

3.7.2.1. Determinação de celulases ........... 55

3.7.2.2. Determinação da Celulase Total (FPA) . . 56

3.7.2.3. Determinação do Açúcar Redutor ....... 57

3.7.3. Análises Estatisticas ............... 57

3.7.3.1. Análises Estatisticas aplicadas na seleção de variantes para maior produçầo .. 
Página

3.7.3.2. Análises Estatísticas aplicadas á dosagem enzimática $\quad \ldots \ldots \ldots \ldots \ldots \ldots . \ldots \ldots$

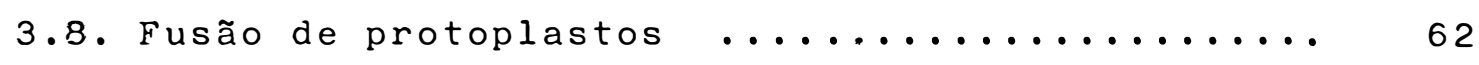

3.8:1. Fusão de Protoplastos por tratamento com

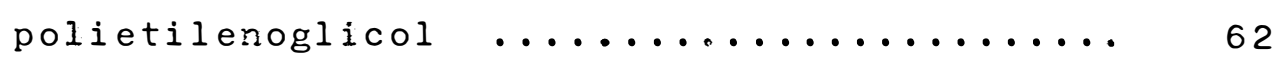

3.8.2. Fusão de protoplastos por eletrofusão .... 64

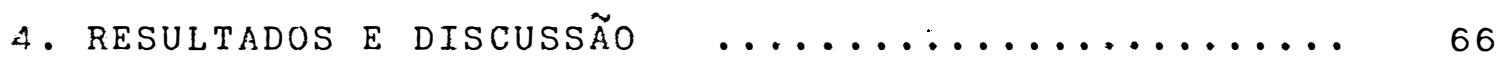

4.1. Técnica. semiquantitativa de avaliação da pro-

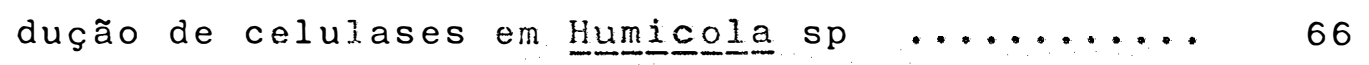

4.1 .1 Visualização do halo e coloração ......... 66

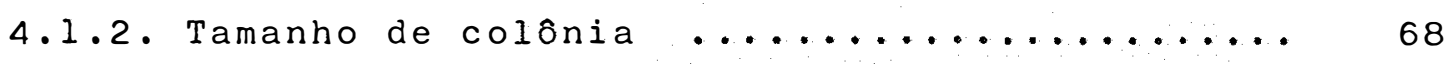

4.1.3. Presença de halo de degradação e índice de atividade enzimática $\quad \ldots \ldots \ldots \ldots \ldots \ldots$

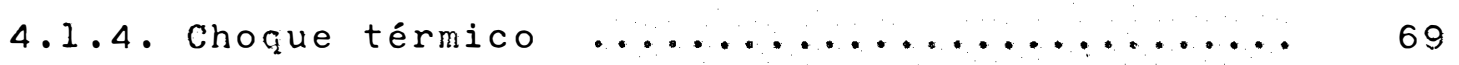

4.2. Protoplastos de Humicola sp $\quad \ldots \ldots \ldots \ldots \ldots . \ldots . \ldots 73$

4.2 .1 . Regeneração de protoplastos ..................... 73

4.2.2. Ourva de sobrevivência de protoplastos á

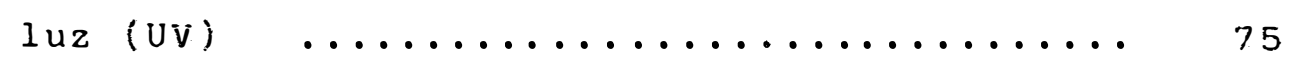

4.2 .3$. Técnica do Doador Morto ................ 77

4.2.4. Liberação de protoplastos a partir do micé-

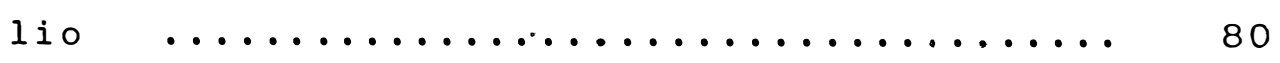

4.2.4.1. Tempo de tratamento enzimático ........ 80

4.2.4.2. Emergência dos protoplastos .......... 82

4.2.4.3. Divisão celular nos protoplastos ...... 82

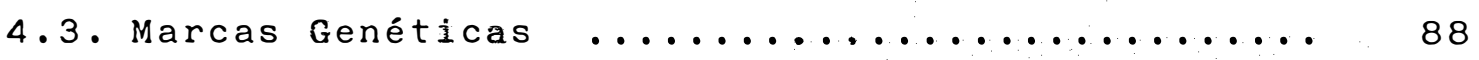

4.3.1. Mutantes Morfológicos $\ldots \ldots \ldots \ldots . \ldots \ldots$

4.3 .2 . Mutantes Desreprimidos $\ldots \ldots \ldots . \ldots \ldots$ 
Página

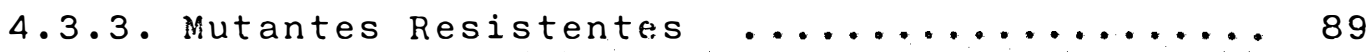

4.3 .3 .1$. Resistência a Benlate ............. 89

4.3.3.2. Resistência a 2-Deoxiglicose ........ 91

4.3.3.3. Resistência a Corantes .............. 93

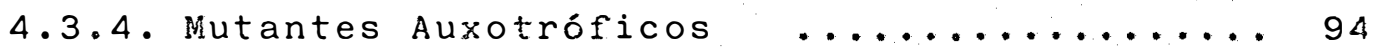

4.4. Seleção de variantes para maior produção de

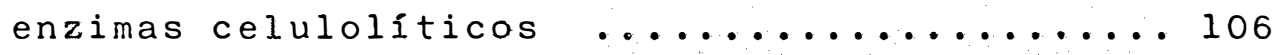

4.4.1. Sistema de seleção em placa .......... 106

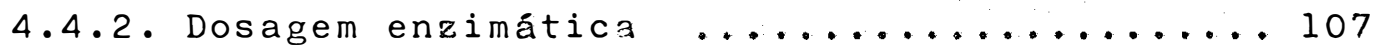

4.4.3. Incremento da produção de enzimas celulo-

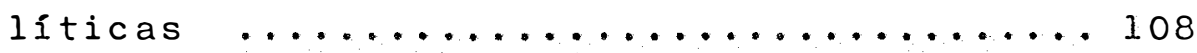

4.5. Fusão de protoplastos $\ldots \ldots \ldots \ldots \ldots \ldots \ldots \ldots$

4.5.1. Fusão de protoplastos por tratamento com polietilenoglicol .....................

4.5.2. Fusão de protoplastos por eletrofusão ... 132

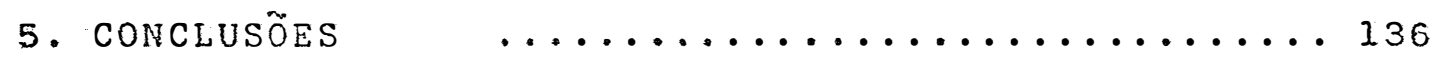

6. Bibliografia consultada $\ldots \ldots \ldots \ldots \ldots \ldots \ldots$ 


\section{LISTA DE FIGURAS}

Fig. 1. Esquema do Método de Caracterização de mutan-

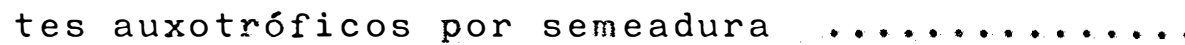

Fig. 2. Esquema de Seleção em placa de variantes para maior produção de enzimas celuloliticas ......

Fig. 3. Esquema do Método para determinação da celulase total, açúcar redutor, peso seco do micélio...

Fig. 4. Esquema da Análise da Atividade de Papel de Filtro para Determinação de Celulose Total.....

Fig. 5. Placa de Petri inoculada com Humicola sp, incubada durante cinco dias, após choque térmico e corada pelo método desenvolvido no presente trabalho $\ldots \ldots \ldots \ldots \ldots \ldots \ldots$

Fig. 6. Curva de sobrevivência á luz ultravioleta de protoplastos de Humicola sp.

Fig. 7. Sequência da obtenção de protoplastos de Humicola sp com diferentes tempos de tratamento enzimático do micélio

Fig. 8. Liberação de protoplastos com 30 minutos de tratamento enzimático ao micélio 
Fig. 9. Protoplastos em divisão nuclear, podendo-se observar cromossomos

Fig. 10. Efeito do tempo de tratamento enzimático nabtenção de protoplastos

Fig. 11. Efeito do tempo de tratamento enzimático na regeneração de protoplastos.

Fig. 12. Mutantes morfológicos obtidos após irradia ção de protoplastos de Humicolㅡㅡ sp com luz UV

Fig. 13. Curva de sobrevivência do Humicola $\mathrm{sp}$ selvagem ao fungicida Benlate 105

Fig. 14. Atividade total de Celulase Extracelular na escolha do meio para produção de celula ses

Fig. 15. Atividade total de Celulase Extracelular em Humicola selecionadas

Fig. 16. Regressões polinomiais da atividade total de Celulase Extracelular de cada uma das 4 variantes estudadas 
Fig. 17. Distribuições de frequência para os valores do Índice de Atividade enzimática para os

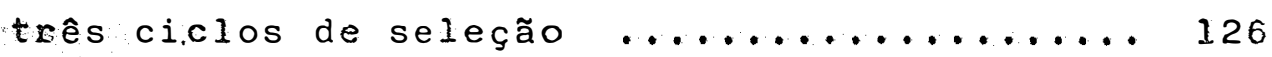

Fig. 18. Distribuições de frequência para os valores do Índice de Atividade Enzimática, para os

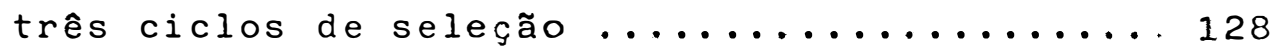

Fig. 19. Protoplastos de Humicola sp fundidos por eletrofusão 
Página

Tabela 1. Diânetros das colônias (medido em $\mathrm{cm})$ de Humicol em 4 meios de cultura por diferentes tempos e temperaturas. (média de 5 repetições). $\ldots \ldots \ldots \ldots \ldots \ldots$

Tabela 2. Índices de Atividade Enzimática de Humicola sp em 4 meios de cultura em diferentes tempos e temperaturas de incubação (média de 5 repetições).

Tabela 3. Efeito da temperatura e concentração do estabilizador osmótico na regeneração de protoplastos de 보포으르 sp.

Tabela 4. Porcentagem de sobrevivencia á luz ultravioleta de protoplastos de Humicola sp

Tabela 5. Número de protoplastos regenerados para cada tratamento (média de 3 placas )

Tabela 6. Número de núcleos em protoplastos de Humicola sp, obtidos após diferentes tempos de tratamento enzimático ... 
Página

Tabela 7. Número de protopiastos/ml obtidos em diferentes tempos de tratamento enzimático; \% regeneração e seu diâmetro....8 83

Tabela 8. Sobrevivência do Humicola $\mathrm{sp}$ selvagem ao fungicida Benlate $(0,0$ a $1,0 \mathrm{ug} / \mathrm{ml}) \ldots 96$

Tabela 9. Sobrevivência do Humicola sp selvagem ao fungicida Benlate $(0,3$ a $0,4 \mathrm{ug} / \mathrm{ml}) \ldots 97$

Tabela 10. Aumento de resistência ao Benlate a partir de duas colônias ( $A$ e B) resistentes a $0,4 \mu g$ de Benlate/ml de MC ..... 97

Tabela 11. Resistência do Humicola sp selvagem à 2-Deoxiglicose $\ldots \ldots \ldots . \ldots . \ldots . \ldots 98$

Tabela 12. Resistência do Humico을 sp selvagem e de colônias, previamente crescidas em meio com 2-beoxiglicose, à 2-Deoxiglicose 98

Tabela 13. Curva de resistência do selvagem à Acriflavina 99

Tabela 14. Curva de resistência do selvagem ao Cristal Violeta 
Página

Tabela 15. Caracterízação preliminar de mutantes auxotróficos

Tabela 16. Resistêricia dos mutantes auxotróficos ao Benlate, Acriflavina e Cristal Violeta em Meio Completo ............ 102

Tabela 17. Resistência dos mutantes auxotróficos ao Benlate, Acriflavina e Cristal Violeta em Meio Completo .............. 102

Tabela 18. Resistência ao Benlate e Cristal Violeta dos mutantes auxotróficos 1 e 3 e dos seus isolados $1_{1}, 1_{2}, 1_{3}, 1_{4}, 3_{1}$,

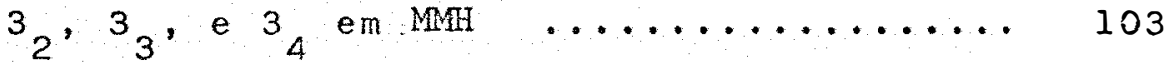

Tabela 19. Análise de Variância em blocos ao acaso para a variável Índice de Atividade Enzimática do primeiro ciclo de sele ção

Tabela 20. Análise de Variância em blocos ao acaso para a variável Índice de Atividade Enzimática do segundo ciclo de seleção 
Página

Tabela 21. Análise de Variância em blocos ao acaso para a variável Índjce de Atividade Enzimática do terceirociclo de seleção

Tabela 22. Análise de Variância em blocos ao acaso para a variável Índice de Atividade Enzimática entre os segundo e terceiro ciclos de

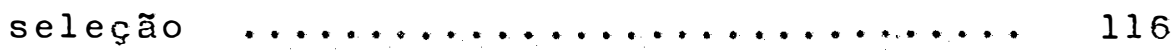

Tabela 23. Peso seco do micélio (mg) e atividade total de celulase extracelular (FPA) $\left(x 10^{-5} \mathrm{IU} / \mathrm{mg}\right)$ em meio E e meio de Petterson et alii (1963)

Tabela 24. Dosagem das variantes selecionadas Peso seco do micélio (mg) e atividade total de celulase extracelular (FPA) $\left(x 10^{-6} \mathrm{IU} / \mathrm{mg}\right) \quad \ldots \ldots \ldots \ldots \ldots \ldots \ldots$

Tabela 25. Análise de Variância em factorial para Dosagem da atividade enzimáti-

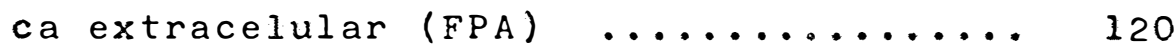


Página

Tabela 26. Estimadores estatisticos das distribuições de frequência para os valores do Índice de Atividade Enzimática para os três ciclos de seleção .......... 122

Tabela 27 . Incremento em porcentagem da atividade enzimática (FPA) das variantes selecio nadas em cada ciclo em relação ao sel-

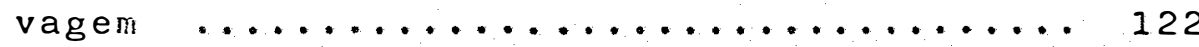

Tabela 28. Fusão de protoplastos de mutantes auxotróficos de Humicola $\mathrm{sp}$ por tratamento com polietilenoglicol............131

Tabela 29. Sobrevivência e Regeneração de protoplastos de Humicola sp após tratamento com Sacarose $0,8 \mathrm{M} \mathrm{pH} 5,6 \mathrm{e}$ 7,0 , após 9 dias de incubação

Tabela 30. Regeneração de protoplastos de Humicola $\mathrm{sp}$ após tratamento com meio para eletrofusão de sorbitol $0,8 M$ e $1,2 M$ pH 7,0 , após 9 dias de incubação 


\section{PRODUCÃO DE CELULASES E FUSĂO DE \\ PROTOPLASTOS EM Humicola sp.}

Autor: EDISON NEIROTTI ROUMAS

Orientador: Prof.Dr. JOÃO LÚCIO DE AZEVEDO.

\section{RESUMO}

o presente trabalho teve por objetivo desenvol ver a tecnologia de fusão de protoplastos em Humicola sp com a finalidade do seu estudo genético, visando incrementar a sua produç̃o de celulases e estabelecer um programa de melhoramento genético para este fungo. Nesse plano foram estudadas entre outras, a otimização da regeneração de protoplastos, a sobrevivência à luz ultravioleta, a obtenção de mutantes e a seleção de variantes de maior produção de enzimas celuloliticas.

Dado que o Humicola sp apresenta conídios multinucleados, a obtenção de mutantes foi realizada por irradia.ção de protoplastos com luz ultravioleta. Do estudo de obtenção de protoplastos, tempo de tratamento enzimático do micélio e número de núcleos presentes por protoplasto, foi observado que com tratamentos por períodos curtos de tempo ( $30 \mathrm{mi}-$ nutos) obtinha-se a maior porcentagem de protoplastos uninuclea dos, condição favorável para a obtenção de mutantes. 
Para a seleção de variantes de. maior produção de enzimas foi necessário o desenvolvimento de uma técnica simples, especifica para a linhagem de Humicola es estudada, que permitisse de forma fácil e rápida quantificar a produção de celulases. A produção de celulases, das variantes selecionadas, foi quantificada pela determinaça da celulase total (FPA).

Finalmente foram estudadas as condições de fusão de protoplastos, na linhagem utilizada, por tratamento com polietilenoglicol e pela técnica de eletrofusão. 
CELLULASES PRODUCTION AND PROTOPLASTS

FUSION IN Humico을 $\mathrm{sp}$.

\author{
Author: EDISON NEIROTTI ROUMAS \\ Adviser: Prof. Dr. JOÃO LÚCIO DE AZEVEDO
}

SUMMARY

The present work attempts to develop the protoplast fusion technique in Humicola sp to study it genetically, in order to increment cellulases production and to establish a genetic improvement programm for this fungus. Among others the optimization of protoplasts regeneration, their survival to UV irradiation, mutant induction and hyper-cellulolytic variants selection were studied within this programm.

By the fact that Humicola sp presents multinucleated conidia, mutant induction was done by protoplasts UV irradiation. From the protoplast formation study, enzimatic mycelium treatment time and protoplast nuclei number, was observed that with mycelium treatments by short periods of time ( 30 minutes) the highest percentage of uninucleated protoplasts were obtained, a wished condition for mutants induction. 
For Hyper-cellulolytic variants selection was necessary to develop a simple technique, specific for the Humicola sp studied strain, that allows in an easy and rapid manner to quantify the cellulase production. The selected variants cellulase production, was quantified by the measurement of the total cellulase (FPA).

Finally the protoplast fusion conditions, in the strain used, were studied by polyethyleneglycol treatment and by electrofusion. 
1. INTRODUÇ̃̃O

Com o aumento da população mundial inúmeros problemas surgiram, destacando-se entre os mais graves, os da produção de energia e aiimentos, intimamente associados, pois o aumento da produça de alimentos implica um aumento no consumo de energia.

o inevitável esgotamento, num futuro não muito distante, das fontes de energia tradicionais, petróleo e carvão minerai, estimulou o estudo de novas fontes para substituilas. Entre as mais promissoras encontra-se a energia solar, que tem como vantagens as caracteristicas de ser uma fonte inesgotável, renovável, econômica e não poluente. A natureza há mujto tempo a vem utilizando e, através da fotossintese, armazenando produtos que podem ser empregados como fontes de alimento e energia.

A disponibilidade da celulose em quantidade tão imensa e o fato de ser renovável tornam-na matéria prima mais interessante para a produção de alimentos e energia. O advento da crise energética do petróleo na década dos anos 70 fez vol- 
tar a atenção das pesquisas para o desenvolvimento de fontes energéticas alternativas e renováveis, sendo que a biomassa é uma fonte potencial. Assim a solução para uma série de pro-. blemas energéticos, químicos e de alimentos, poderia ser a hi drólise de celulose, a glicose, e a partir desta a obtenção de combustiveis liquidos, produtos quimicos e materiais ali-mentares.

A celulose é a única fonte de carbono renovável que é encontrada em grandes quantidades. A quantidade de carbono fixada por fotossintese tem sido estimada entre 70 e 100 bilhões de toneladas por ano sendo que a metade dela é celulose. A fração dela que pode ser coletada a um custo razoável é baixa, mas pode ser incrementada significativamente melhorando o seu manejo.

A celulose podeser hidrolisada a produtos solúveis por ácidos ou enzimas. A desvantagem da hidrólise ácida é que pode resultar em decomposição da glicose inicialmente formada; nesse caso, os produtos resultantes da decomposição,aldeidos e cetonas, são tóxicos para microrganismos e animais superiores. Além disso os ácidos minerais utilizados para a hidrólise provocam a corrosão dos equipamentos utiliza dos e interagem com materiais não celulósicos na celulose natural. Tudo isto resulta em baixo rendimento, impurezas no me laço, e um custo alto. A hidrólise enzimática da celulose tem a vantagem de ter uma conversão eficiente sem a produção de compostos secundários indesejáveis. E preferível então a uti lização de um processo enzimático igual ao caso da hidrólise 
do amido. Infelizmente o custo de produção da celulase microbiana é alto. A utilização com êxito do material celulósico como fonte de carbono renovável depende do desenvolvimento de processos e tecnologias econômicas para a produção de celulases, a hidrólise microbiana e enzimática do material celulósi co a produtos de baixo peso molecular tais como hexoses e pen toses, e a conversão química ou biológica destas em outros produtos úteis paraserem utilizados como combustível liquido produtos quimicos e produtos alimenticios.

No que diz respeito à microbiologia e à genéti ca microbiana, hoje estão se desenvolvendo numerosos trabalhos cujos objetivos são reduzir este custo desenvolvendo mutantes regulatorios celuloliticos. Estes mutantes seriam lisados na produção comercial de celulase de baixo custo e para o estudo dos mecanismos que controlam a sintese enzimática.

o presente trabalho tem como objetivos: 1. es tabelecer uma metodologia de melhoramento genético para o fingo celu lolitico das características do Humicola sp ( reprodução sexuada desconhecida, com conídios multinucleados e hifas septa das multinucleadas), avaliando a sua potencial adequação em futiros projetos de melhoramento em microrganismos de caracte risticas similares. 2. desenvolver a tecnologia de fusão de protoplastos neste fungo com a finalidade do seu melhoramento genético, visando assim, incrementar a sua produção de celula ses. 
2. REVISÃO DE LITERATURA

2.l O Complexo Celulase. Biossintese e Regulação.

Diversos microrganismos produzem celulases entre os que estão incluídas muitas espécies de fungos, actinomi. cetos e outras bactérias. COUGHLAN (1985) cita diversas espé cies pertencentes a alguns gêneros bacterianos, entre os quais podem ser destacados: Cellulomonas, Cellvibrio, Clostridium, Pseudomonas; entre os actinomicetos destacam-se: $\underline{\text { streptomyces, }}$ e Thermomonospora e entre os fungos: Aspergillus, Fusarium, Penicillium, Polyporus, Sporotrichum, Trichoderma, Humicola. Porém, deve-se destacar que somente os fungos excretan gran des quantidades de celulases na sua forma ativa no meio de cul tura, enquanto que as celulases bacterianas estão principalmen te ligadas à parede celular (wOOD, 1985).

Alguns organismos podem consumir rapidamente to das as formas de celulose, outros podem consumir apenas formas degradadas da mesma (REESE, 1976). RYU \& MANDELS (1980) atra- 
vés dessas observações e baseados na hipótese $C_{1}-C_{x}$ (REESE et alii, 1950) confirmaram como estabelecido por estes autores que a celulose natural é hidrolisada em 2 ou 3 passos, chegan. do ao seguinte conceito do complexo celulase:

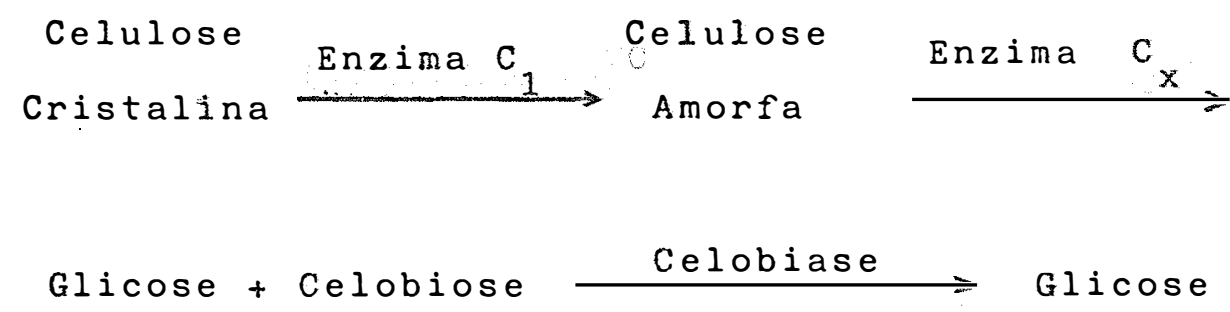

Algumas bactérias e fungos produzen só um tipo de celulase (endocelulase), a qual por si mesma, não é capaz de hidrolisar suficientemente a celulose. Os organismos celuloliticos verdadeiros são saprófitas que obtem a sua energia degradando materiais celulósicos. Eles são capazes de produzir um complexo celulolitico, isto é, uma mistura de enzimas celu loliticas com diferentes modos de ação. Esse complexoceluloli tico é capaz de hidrolisar eficientemente a celuiose cristalina a açúcares solúveis.

Um ponto no qual todos os autores concordam é que a celulase é um complexo de enzimas que atuam sinergisticamente na hidrólise da celulose cristalina.

Diversos autores IGONG \& TSAO, 1979; MONTENE-COURT et aIii, 1979; LEE \& FAN, 1980; RYU \& MANDELS, 1980) afirman que o complexo celulase é formado por, pelo menos, 3 enzimas comumente chamadas exocelulase, endocelulase e celobiase. Em geral os microrganismos não produzem todas as enzi 
mas do complexo celulolitico em proporções iguais. Assim o gênero Trichoderma, em especial o $\underline{\text { Tre }}$ ései considerado o melhor produtor de celulases extracelulares, é um bom produtor de exo e endocelulases, porém produz pouca $\beta$-glicosidase; em com pensação esta última é produzida em abundante quantidade por algumas espécies de Penicillium (FUNAGUMA et alii, 1986; BROWN et alii, 1987a) e Humicola (ARAUJO et alii, 1983).

A exocelulase segundo GONG \& TSAO (19.79), encontrada exclusivamente em fungos filamentosos, é capazde degradar a celulose cristalina. A celulase bacteriana e a endocelulase fúngica não tem atividade hidrolitica sobre a celulo se cristalina. São celulases que retiram as unidades de glico se e celobiose terminais das cadeias. A produção de exocelula setem como indutores à celulose e lactose (GONG \& TSAO,1979) e é inibia competitivamente pelo produto final, a celobiose (HALLIWELL \& GRIFFIN, 1973), e também pela glicose, mas com menor intensidade.

A endocelulase hidrolisa as cadeias de celulose ao acaso, atacando os polímeros de celulose internamente (RYU \& MANDELS, 1980). Tem atividade limitada sobre a celulose cristalina, mas a presença desta enzima aumentaa atividade da exoglucanase na hidrólise da celulose cristalina. Isto é devido aos ataques ao acaso da endocelulase sobre a celulose - qual cria novos sitios terminais reativos para a exocelula se (GONG \& TSAO, 1979; ARAUJO \& D'SOUZA, 1986). Esse efeito complementar da endocelulase com a exocelulase é chamado de efeito sinergistico da celulase. Segundo FUJII \& SHIMIZU -- 
(1986) o sinergismo entre Endo e exocelulases se dá nas primeiras etapas da reação de hidrólise da celulose. Nelas a endccelulase quebra a molécula do substrato formando novos sítios terminais para a exocelulase até que o peso molecular do substrato atinge valores baixos (4.000); abaixo deste valor a endocelulase deixa de agir e a cinética da reação obedece só a equação de reação da exoenzima.

A celobiase hidrolisa a celobiose a glicose. Esta enzima é importante na regulação da indução da celulase assim como na regulação da celulólise. In vivo a celobiase hi drolisa a celobiose exógena a glicose, regulando assim o nível de glicose e celobiose intracelular, o que influência nabiossintese de celulase através do mecanismo de indução-repressão.

Resumindo, pode-se dizer que a celulose é um polimero linear não ramificado contendo unidades de glicose II gadas por enlaces $\beta(1-4)$ glicosideos os quais são hidrolisam dos pelas enzimas celuloliticas. Porém, em uma microfibrila de celulose onde as cadeias estão ordenadas, ocorrem poderosas pontes de hidrogênio, resultando em uma estrutura cristalina. Isto dá à celulose sua insolubilidade, sua força tensoativa, e sua resistência a enzimạs e reagentes químicos. Onde as cadeias são menos ordenadas a celulose é amorfa, e portanto mais rapidamente hidratada e mais acessivel às enzimas. Tais áreas amorfas podem ser hidrolisadas até certo grau por endo ou exoglucanases agindo separadamente, ou por celulases incompletas. Para a hidrólise da celulose cristalina onde as pontes de hidro gênio assim como os enlaces glicosidicos devem ser quebrados é necessário a presença de uma celulase completa contendo um nivel adequado de todos os componentes. 
Embora ainda não tenham sido completamente esclarecidos os mecanismos da reação e as interações sinergísti cas envolvidas na hidrólise enzimática da celulose, o modelo atual é mostrado no seguinte esquema (RYU \& MANDELS, 1980):

$$
\begin{gathered}
\text { Endo- } \beta-(1-4)-\text { glucanase } \\
(\text { EC } 3.2 \cdot 1.4)
\end{gathered}
$$

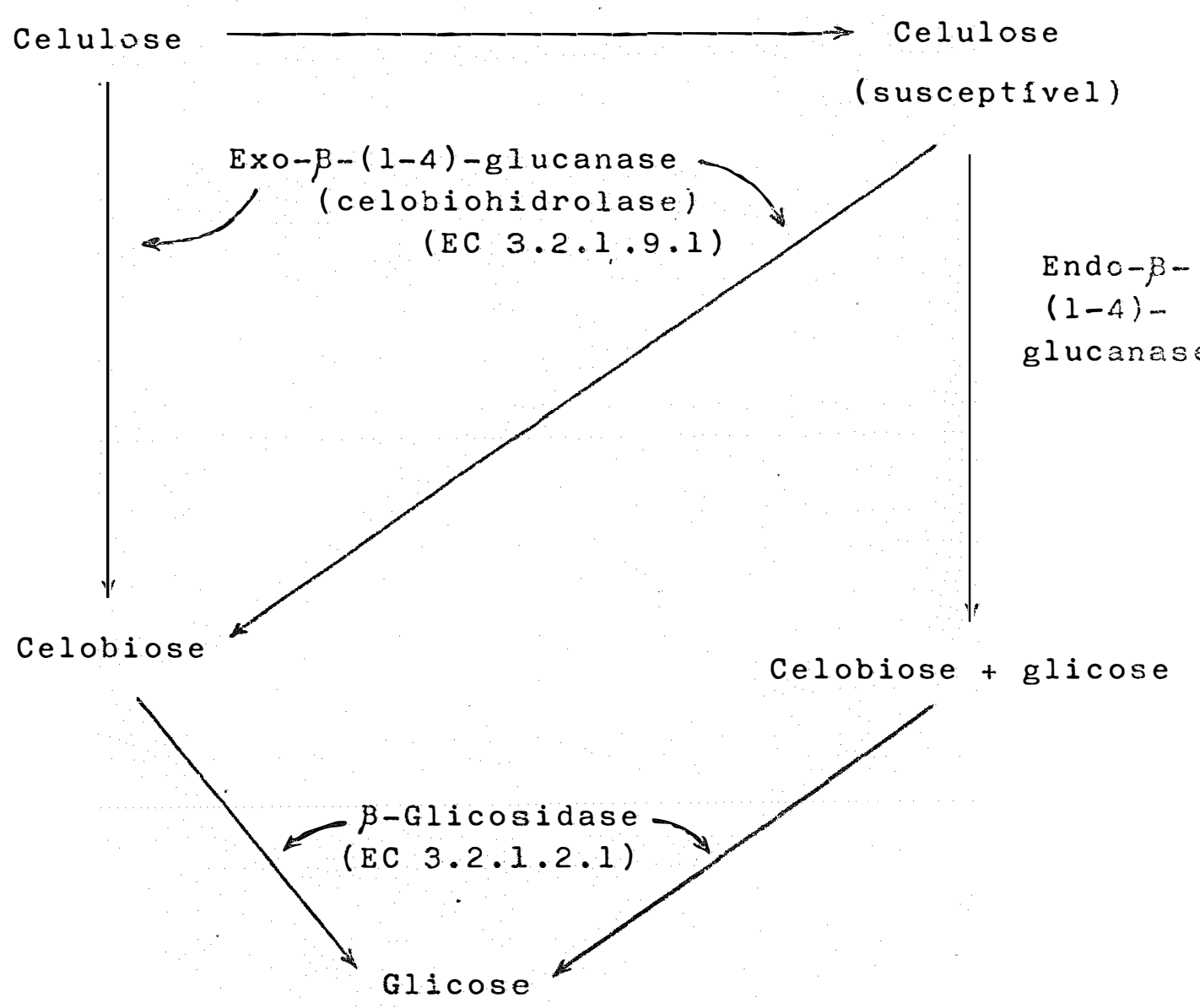

A utilização da celulose pelos microrganismos celuloliticos é um processo muito lento. Os microrganismos hidrolisam celulose em açucares metabolizáveis pela produção 
de um complexo sistema enzimático. A celulase extracelular po de ser produzida pelos organismos em resposta à presença de certos substratos no meio de crescimento. Entre os indutores da sintese de celulase incluem-se celulose, derivados da celu lose, celobiose, soforose e lactose.

A resposta do fungo aos diferentes indutores varia dependendo da concentração e tipo de indutor (MANDELS et alii, 1975; ROMANELLI et alii, 1975).

A sintese da celulase indutiva também pode sofrer inibição pela presença de glicose ou outros açúcares no meio. Assim a síntese de celulase por microrganismos está regulada por um mecanismo de indução-repressão.

$\mathrm{Na}$ maioria dos sistemas de enzimas induziveis, - indutor entra na célula por transporte ativo ou por difusão. Uma vez dentro da célula, o indutor interage com o repressor tornando-o inativo, o resultado é a síntese da enzima (JACOB \& MONOD, 1961). As celulases são enzimas induzíveis, incluindo-se entre os indutores a celulose, celobiose, soforose, lac tose e alguns outros açúcares. A celuiose é o indutor universal da sintese da celulase, porém, não é conhecido como a celúlose, um subtrato insolúvel, entra na célula. Tem sido proposto que o contato intimo entre a celulose e o microrganismo celulolitico provoca a indução e síntese da celulase (BERG \& HOFSTEN, 1976; RAUTELA \& COWLING, 1966), mas, isto está em con traste com o conceito geralmente aceito de indução. MANDELS \& REESE (1960) propuseram que pequenas quantidades de enzima podem ser produzidas pelas células e liberadas ao meio. A enzima então hidrolisa a celulose, provindo assim uma quantia limita- 
da de celobiose a qual pode agir como indutor. Este fenômeno é conhecido como "síntese basal" em outros sistemas enzimáticos indutiveis. GONG \& TSAO (1979) evidenciaram que O T.reesei também apresentava o fenômeno de síntese basal, produzindo traços de celulase em forma independente da fonte de carbono e ainda sob condições de carência (starvation), o que indica que esta sintese basal da celulase é constitutiva. HULME \& STRANK(1970,1971) afirmam que a sintese da celulase é constititutiva e está regulada, somente, por repressão catabólica. A capacidade da celulose para induzir a sintese de celulase depende da capacidade dos organismos em produzir "celulase basal". Sporotrichum tem uma quantia de celula se basal maior que Trichoderma, assim, a lag fase da indução pela celulose é mais curta em Sporotrichum (ERIKSSON \& HAMP, 1978). A "síntese basal" de celulase fornece uma quantia limi tada de glicose e celobiose no meio de crescimento contendo celulose. A celobiose é um indutor da celulase na maioria dos organismos celuloliticos e a concentração da celobiose é importante na regulą̧ão da sintese da celulase em muitos micror ganismos. A resposta dos organismos à concentração de celobio se depende da linhagem. Em baixa concentração a celobiose " é um bom indutor, enquanto que em alta concentração a celobiose inibe a sintese da celulase (MANDELS \& REESE, 1960). Quando a concentração de celobiose no meio é alta, a celobiose pode ser hidrolisada pela celobiase intracelular depois de ter entrado na célula. Isto causa o acúmulo de glicose e assim a repressão.

A sintese da celulase é reprimida pela presen- 
ça no meio de glicose e outros açúcares rapidamente metabolizáveis e este fenômeno é conhecido como repressão catabólica. A repressão catabólica dada pela glicose é chamada de "efeito glicose". A repressão da sintese da celulase em Trichoderma é mais intensa quando a glicose está presente. MANDELS (1975) relatou que a sintese da celulase pode ser inibida pela preserça de glicose no meio ainda em presença de um indutor. A sintese de celulase recomeça depois da glicose ter sido consu mida ou depois de transferir as células do meio com glicose para um meio com indutor.

Dado que um dos processos propostos para a uti lização da celulose é a sua hidrólise enzimática seguida da fermentação dos açúcares produzidos. TAKAGI et alii (1978) e monstraram que a sacarificação e fermentação simultáneas é um método efetivo na produção de etanol a partir da celulose. TAKAGI(1984) afirma que a degradação mais acelerada da celulo se por este método deve-se a uma menor inibição da celulase pelo etanol que pela glicose e/ou celobiose.

CHAPMAN \& LOWENBERG (1976) tem demonstrado que a tradução da enzima ocorre no citoplasma ou no reticulo endo plasmático o qual está incorporado dentro do complexo de Golgi e assim a celulase ou seus precursores sintetizados encontram -se dentro da célula. Do complexo de Golgi desprendem-se vesiculas contendo celulase, estas vesiculas que estão inicial mente no citoplasma, mais tarde fundem-se com a membrana plas mática e liberam seu conteúdo no meio por exocitose. Quando a formação da celulase é induzida, o aparecimento de vesiculas contendo celulase no citoplasma, precede em cinco horas 
ao aparecimento da celulase no meio.

o contato intimo entre a celulose e as células do organismo é essencial para que ocorra a celulólise. A cel $\underline{u}$ lose pode ser hidrolisada pela celulase ligada ao sistema de membrana, mas na maioria dos fungos filamentosos, a celulolise ocorre fora da célula. Assim para a célula utilizar a celulose, nova enzima celulolitica deve ser sintetizada e liberada no meio. O mecanismo excretor da celulase em alguns casos é inespecifico e ocorre principalmente durante a lise da célula. Em outros casos acredita-se que a excreção da celulase é um pro cesso especifico influenciado pela fonte de carbono, pH, e al guns outros fatores do ambiente (MANDELS, 1975; COUTTS \& SMITH, 1976). ERIKSSON \& HAMP (1978), estudaram a regulação da endoce Iulase em Sporotrichum e Trichoderma reesei, e verificaram que depois da indução o aparecimento de celulase intracelular quase imediatamente seguido pelo aparecimento de celulase extracelular. Isto indica que a excregão da endocelulase em al guns fungos filamentosos é um processo especifico e não um pro cesso inespecífico que ocorre quando há lise celular.

Há muitas evidências que sugerem que ambas as en zimas, endocelulases e exocelulases são co-induzidas, pelos indutores da celulase. Os mutantes bons produtores de celulases produzem quantidades elevadas de ambas celulases (MANDELS et alii, 1971; MONTENECOURT \& EVELEIGH, 1977b). A indução e repressão simultânea de ambas celulases sugere um mecanismo de regulação coordenado análogo ao descrito para a enzima $\beta$-ga lactosidase em Escherichia coli. A celobiose estaria regulada por um mecanismo regulatorio diferente. 


\subsection{O gênero Humicola.}

O gênero 브늠으르 é constituido por fungos des providos de reprodução sexuada, pertencente à classe Deutero micetes e à família Dematiaceae. Diversas espécies deste gêne ro tem sido isoladas do solo, compostagem e madeira em decomposição (HARRINGTON et alii, 1979; MAZEN et alii, 1980; DEORAY \& BHIDE, 1981; KLEYN \& WETZLER, 1981; LYSEK et alii, 1982; AB:DEL-KADER et alij, 1983; MOWE et alii, 1983).

Algumas espécies deste gênero tem sido estudadas devido ao interesse comercial que elas possuem; assim Humicola Iutea 120-8:1 e 1 으느늘 72 apresentám atividade de protease á cida (ALEXIEVA et alii, 1980; NIKOLOVA et alii, 1980; GRIGOROV et alii, 1983). Por sua vez, Humicola sp ATCC 20620 apresenta atividade de rifamicina oxidase (LEE et alii, 1984; SEONG et alii, 1985). Humicola lanuginosa produtor de proteinase (SHENOLIKAR \& STEVENSON, 1982), produtor de glucoamilase (TAYLOR et alii, 1978) e H. lanuginosa var catenulata produtor de lipase(MORINAGA et alii, 1986).

Os fungos termofilicos estão entre os numerosos microrganismos que tem capacidade de produzir hidrolases extra celulares. Este tipo de microrganismo é interessante para : a produção de enzimas em grande escala em fermentações submersas e em substrato sólido.Um"dos problemas técnicos das fermentações é manter a temperatura no nivel adequado durante todo o período do processo. O uso de linhagens termofilicas pode ser uma solução para este problema, já que enzimas destes mi crorganismos são estáveis a temperaturas mais altas que as 
enzimas de linhagens mesofilicas. Além disso o uso de enzimas termoestáveis resulta num incremento da hidrólise e inibição do crescimento de outros microrganismos. Na literatura existe suficiente informação a respeito da produção de enzimas celuloliticas por parte de fungos termofilicos em fermentaços submersas (COUTTS \& SMITH, 1976; CANEVASCINI et alii, 1979 ; TRIVEDI \& RAO, 1979; STEWART \& PARRY, 1981; ARAUJO et alii,1983; GOTTSCHALK et alii, 1984; SHAKER et alii, 1984; WASSERMAN, 1984; WASE et alii, 1985; COSSAR \& CANEVASCINI, 1986; HAYASHIDA \& MO, 1986; TAMADA et alii, 1986; MORRISON et alii, 1987) e pouca in formação em fermentação de substratos sólidos ( GRAJEK, 1987 ). A maior parte dos trabalnos sobre o gênero Humicola tratam de espécies termofílicas, sendo que uma boa parte das mesmas são produtoras de celulases. Por exemplo, Humicol do de tabaco é termofilico e capaz de produzir amilase e celu-

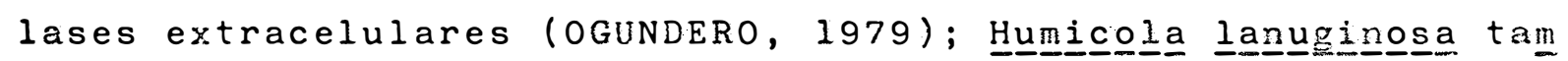
bém termofilico e produtor de celulases (OGUNDERO, I981). Ambas espécies apresentaram atividade.de FPA (JAIN, 1979). HAYASHIDA \& YOSHIOKA (1980) isolaram de esterco um fungo termofi

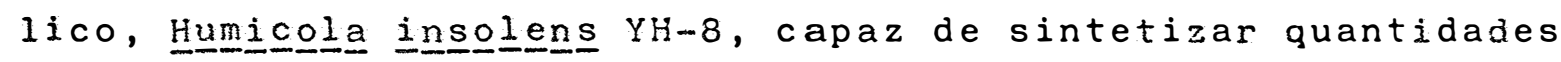
significativas de celulase termoestável, em meio de cultura com farelo de trigo, após quatro dias de crescimento a $500 \mathrm{C}$. YOSHIOKA et alii (1982) encontraram que Humicola grisea var. thermoidea YH-78 era bom produtor de endocelulase quando cresci do durante quatro dias a $509 \mathrm{C}$ em farelo de trigo.

0 fungo. Humicola sp estudado no presente. trabalho foi isolado de compostagem e mostrou-se capaz de produzir o complexo celulase parcialmente associadoà massa celular 
quando crescido em celulose microcristalina. Apresenta conidióforos curtos, com conídios globosos unicelulares, escuros formados no ápice do conidióforo(CHAVES,1982). É um fungo ter mofilico carente de reproduçäo sexuada, com conídios multinucleados e hifas septadas multinucleadas. Apresentou um melhor crescimento a $42^{\circ} \mathrm{C}$ e pH 6,0 e altos niveis de produção de ati vidade de $\beta$-glicosidase. ARAujo et alii ( 1983 ) observaram que a atividade extracelular de $\beta$-glicosidase de Humicola quatro vezes maior que a de Trichoderma reesei. QM 9414. As características deste fungo despertaram o interesse de diversos pesquisadores que fizeram alguns estudos em diferentes as pectos. Por exemplo, MONTI et alii, (1984) estudaram a regulação da sintese do complexo celulase; MORAES et alii (1985) ca racterizaram a sua $\beta$-glicosidase. HARGER et alii (1986) em meio com glicose como única fonte de carbono, encontraram que - Humicola sp apresentou atividade intracelular constitutiva ; MONTI \& JORGE (1986) tentaram otimizar as condições para a produção de celulases; POLIZELI \& TERENZI (1986) estudaram o ereito da glicose sobre a atividade da $\beta$-glicosidase; VIEIRA \& PRADE (1986) avaliaram o efeito da repressão catabólica na biossintese das suas enzimas celuloliticas; XIMENES \& FELIX (1986) isolaram e caracterizaram a B-glicosidase intra e extracelular. Mais recentemente, MONTI \& JORGE (1987) purificaram uma xilanase extracelular;PERALTA \& JORGE (1987) estudaram a produção de $\beta$-glicosidase e $\beta$-galactosidase em diferentes condições de cultivo enquanto ZIMMERMANN \& JORGE (1987) es tudaram a sua atividade Je trehalase. Foram feitos também estudos cito genéticos de mutantes morfológicos e a dosagem bioquímica dos mesmos (R0 DRIGUEZ, 1987). 


\subsection{Protoplastos}

\subsubsection{Esferoplastização.}

A liberação de conteúdo citoplasmático na forma de protoplastos discretos a partir de células de fungos é mais facilmente conduzida usando uma mistura de enzimas liticas degradadoras de parede na presença de um estabilizador os mótico. Nos 20 anos que seguiram às primeiras observações sobre o isolamento de protoplastos em leveduras (EDDY \& WILLIAM SON, 1957) e em fungos filamentosos (EMERSON \& EMERSON, 1958; BACHMAN \& BONNER, 1959) foi conseguido um progresso considerá vel nos métodos de obtenção de protoplastos. Isso foi devido, principalmente, à descoberta de novas enzimas (PEBERDY, 1985a). As enzimas utilizadas no presente trabalho, Novozym 234 e Celulase CP tem atividade de quitinase e or e $\beta-1,3-g l u c a n a s e$. A Novozym 234 é produzida pela Novo Industri A/S, Denmark a partir do Trichoderma sp e a Celulase CP produzida pela Johr e E. Sturge Ltd., England a partir do Penicillium funiculosum. Segundo HAMLYN et alii (1981) esta última enzima aumentava a atividade da Novozym 234 melhorando sua eficiência o que se traduz numa maior obtenção de protoplastos. o tempo de tratamento enzimático na obtenção.de protoplastos é importante pois uma incubação prolongada pode inviabilizar os primeiros prototoplastos liberados, ou mesmo regenerando formar hifas aber rantes (GABRIEL, 1968). Além das enzimas líticas e do tempo de tratamento do micélio com as mesmas, os estabilizadores osmóticos, a idade fisiológica do fungo e as condições e composí ção do meio de cultivo do mesmo, também são importantes deter- 
minarites da produção de protoplastos (DAVIS, 1985).

Devido à retirada da parede celular os protoplas tos são células osmoticamente sensiveis, sendo assim de grande importância a utilização de estabilizadores osmóticos adequados. Diversos tipos ae estabilizadores osmóticos, incluindo sais inorgânicas, açúcares e açúcares-álcoois, têm sido utilizados pa ra estabilizar protoplastos. O tipo de estabilizador e a sua con centração são os fatores que influencian sobre a obtenção e a estabilidade dos protoplastos; estos fatores variam de uma espécie para outra, e portanto não existe um estabilizador osmótico "universal" adequado para todos os fungos. Em geral os sais inor gânicos são mais adequados para fungos filamentosos enquanto que os açúcares e açúcares-álcoois o são para as leveduras(DÂVIS, $2985)$.

Em geral são obtidos mais protoplastos de micéIios que se encontram em fase exponencial de crescimento que em micélios em fase estacionária ( BENITEZ et alii, 1975; DEUTCH \& PARRY, 1974; PEBERDY et alii, 1976; SCHWENCKE et alii, 1977). SAGARA (1969) demonstrou que a parede de células jovens de Geotrichum candidum é mais suceptível à ação enzimática e a medida que a cultura tem mais idade há um incremento na resistência à lise da mesma. Porém, em alguns casos tem sido obtido um bom número de protoplastos a partir de micélio em fase estacionária. Por exemplo, em P. chrysogenum em fase estacionária conseguiu-se abundantes protoplastos, sendo sugerido que enzimas Ifticas endógenas podem estar presentes nas suas células (EYSSEN 1977 ).

A utilidade e aplicabilidade da técnica de fusão de protoplastos na genética e melhoramento de fungos 
consequência de muitos estudos básicos na obtenção e cultivo de protoplastos, mas o sucesso na aplicação desta técnica deve-se a uma alta porcentagem de regeneraça e a uma boa frequência de fusão dos protoplastos. Porém, a maior parte dos estudos com protoplastos tem sido microscópicos e fisiológicos, tendo estes contribuido significativamente para o conhecimento atual em muitas áreas de fisiologia e bioquímica de microrganismos (EDDY \& WILLIAMSON, 1957; STREIBLOVA, 1968 ; HA VELKOVA \& MENSIK, 1969; HOUSSET et alii, 1975; BASTIDE et alii 1979). Outra das áreas na qual a esferoplastização tem desernvolvido um papel fundamental, foram os estudos de composiçăo e sintese da parede celular de micrórganismos (NECAS, I971). Até a descoberta da técnica de fusăo de protoplastos, a recombinação genética em fungos só podia ser obtida por processos sexuais ou parassexuais. Ambos são consequên cias de fusão, no primeiro caso de células reprodutivas especializadas no segundo de células somáticas com nucleos geneti camente diferentes. Mediante a técnica de fusão de protoplastos de fungos foi possivel a obtenção de heterocários e de hí bridos entre linhagens e entre espécies que não poderiam ter sido cruzadas por processos convencionais (PEBERDY, 1985b). Porém, a simples produção de protoplastos e sua posterior re generação, não se constitui num sistema de recombinação. No entanto, com esta técnica, surgiu a possibilidade de juntar genomas diferentes em uma mesma célula. Graças a ela foi pos sivel a fusão de protoplastos entre linhagens ou mesmo espécies diferentes, desta forma abriu-se um novo campo que permitiu a obtenção de recombinantes. Inclusive, isso facilitou 
uma das etapas do ciclo parassexual, ou seja; a obtenção de diplóides em fungos (AZEVEDO, 1983).

Eśsa nova técnica de fusão de protoplastos e posterior fusão e núcleos já nos protoplastos, abreviando e facilitando o ciclo parassexual, abriu a possibilidade de rea lizar estudos genéticos em fungos, cuja anastomose entre hifas é dificil ou mesmo impossivel devido a problemas de incompatibilidade; permitiu também que cruzamentos interespecificos pudessem ser feitos visando combinar qualidades favo ráveis de diferentes fungos num mesmo individuo com vistas ao melhoramento genético (PEBERDY, 1979), superando então a barreira da especificidade. Assim a obtenção de novos híbridos interespecificos acabou-se convertendo em uma das mais impor tantes apiicações da tecnologia de fusão de protoplastos.

Outro aspecto interessante do uso de protoplas tos é a transferência de organelas celulares pela fusão dos mesmos, ou seja, o estudo de casos de herança citoplasmática pela fusão de um protoplasto sem núcleo com outro nucleado e verificando-se as caracteristicas do produto formado nestes chamados" cibridos". Também os protoplastos de fungos anuclea dos podern ser utilizados como vetores de material genético de outros microrganismos.

Dentre todos os estudos com protoplastos aquele que teve maior repercussão foi a fusão de protoplastos as sim. esta técnica surgiu como uma opça importante no melhoramento de microrganismos. 
2.3.2. Fusão de Protoplastos

2.3.2.1. Fusão de Protoplastos por tratamento com Polietilenoglicol.

Segundo FERENCZY (1981) a fusäo de protoplas... tos foi observada pela primeira vez por MELLON em 1925 em in protoplastos bacterianos; porém o fenônenc foi questionado por algúm tempo até que SMITH em 1944 e trabalhos pos teriores confirmaram este fato. A descoberta da fusäo espont祀 nea de protoplastos em bactérias foi seguida pela mesma desco bexta em leveduras, Saccharomyces e Candida (MULLR, 1970).

A ocorrência de fusäo espontânea tirha frequần cias muito baixas e foi somente apòs a descoberta, de KAO \& $M I$. CHAYUUKE (1974) em protoplastos de plantas, que polietilenoglicol ( $P E G$ ) atua como agente fusogênico de protoplastos que foi possivel o desenvolyimento de técnicas de fusäo controladas capazes de aumentar a frequência da mesma.

ANNE \& PEBERDY ( 1975 e 1976) determinaram as melhores condições para a fusão de protoplastos utilizando po lietilenoglicol (PEG) como agente fusogénico. Comprovaram que a adição de ions cálcio, na mistura, em concentração de 0.03 M é fundamental para a obterção de uma alta frequência de fusäo. Também estabeleceram que a concentração de PEG deve ser superior a $20 \%$, sendo de 30 a $40 \%$ as concentrações que oferecem melhores resultados.

ANNE \& PEBERDY (1976) realizaram fusões intraespecificas em diversos fungos filamentosos: Penicillium chrysogenum, P. patulum, P. roquefortii, Aspergilius 
nidulars, A. niger e Cephaiosporium acremonium, obtendo heterocários em alta frequência. Mais recentemente, diferentes au tores realizarain trabalhos de fusão de protoplastos intraespe cificos em diversos rungos filamentosos. Assim TOYAMA et alii (1984) realizaram a fusão de protoplastos de duas linhagens de I. reesei produtoras de celulases; KIRIMURA et alii (1986, 1987 ) fundiram duas linhagens diferentes de Aspergillus niger produtoras de ácido citrico;SILVEIRA \& AZEVEDO (1987) fundiram duas linhagens de Metarhizium anisopizae fungo entomopatogêni co utilizado para controle biológico de insetos; também OGAWA et alii (1387) fundiram mutartes morfológicos do Irichoderma reesei QH 9414 obtendo setores de tipo selvagem e com um conteúdo de DNA 1,9 vezes major que os parentais fazencio pensar que tratava-se de diplojdes.

Também foram realizadas com esta técnica diversas fusões interespecificas em fungos filamentosos. KEVEI \& PEBERDY (1977) fundiram protoplastos de Aspergillus nidulans. e A. rugulosus obtendo híbridos diplóides que logo segregaram dando os parentais de morfologia alterada; ANNE et alii (1976) fundiram protoplastos de penicillium chrysogenum e Penicillium roquefortii obtendo hibridos de morfologia e estabilidade variáveis; KEVEI \& PEBERDY (1934) obtiveram fusão de protoplastos entre diferentes espécies de Aspergillus nidulans, A.

rugulosus e A. quadrilineatus. Na fusão interespecffica, a fre quência de complementação de marcas é menor que na intraespecifica sendo que a diferença pode ser de mais de 5 ordens de magnitude (FERENCZY, I981). A hibridąão interespecífica por 
esta técnica em Aspergillus até o presente monento não teve muito sucesso, os produtos de fusão tem crescido em forma pobre tendo sido bastante instaveis e segregaram apenas um dos fenótipos parentais utilizados. A fusão interespecífica em Penicillium parece ter dado melhores resultados sendo mais estável quando a pressão seletiva não está presente a após a segregação todas as marcas genéticas podem ser recuperadas (FERENCZY, 1981; PEBERDY, 1985).

2.3.2.2. Fusão de Protoplastos por Eletrofusão.

É una técnica de fusäo baseada na exposiço das células ou protoplastos a um campe elétrico alternado năo uniforme e de baixa intensidade, seguido pela aplicação de um pulso elétrico curco de alta intensidade.

Esta técnica tem como principais vantagens uma frequência de fusão muito maior que a obtida pela fusâa quín ca; não utiliza compostos tóxicos para a célula como é o caso do PEG que pode afetar a viabilidade dos protoplastos; além disso o processo de fusão de protoplastos pode ser acompanhado no microscópio.

Un dos pré-requisitos para a fusão é que exista um contato intimo entre as membranas das células. o contato de membrana entre pelo menos duas células é conseguido pela dieletroforese, interação mútua entre as células que tem sido convertidas em dipolos pelo campo elétrico alternado não uniforme (POHL, 1978). Com o propósito de fusionar as células 
deve-se estabelecer um contato de membrana mais intimo e para isso deve-se aumentar a intesidade do campo elétrico por um curto período de tempo (ZIMMERMANN \& PILWAT, 1978; ZIMMERMANN \& SCHEURICH, 1981 ).

A iniciação da fusão esta dada por uma corrente elétrica de quebra da membrana na zona de contato. Porém se a membrana celular é polarizada muito rapidamente e numa voltagem mujto elevada essa quebra ejétrica da membrana esta associada a um incremento reversivel na condutividade e per. meabilidade. Desta forma os efeitos induzidos na membrana pe... la quebra elétrica são completamente reversíveis e após um certo intervalo a resistência de membrana e impermeabilidade original são re-estabelecidas;mas se a intensidade ou o tempo de exposição a essa corrente elétrica são intensos demais o fenômeno de quebra elétrica torna-se uma quebra mecânica e ir reversível. pensa-se que a compressão eletromecânica da membrana leva a sua quebra pela formação de poros; a densidade dos mesmos tem sido estimada em $10^{7} / \mathrm{cm}^{2}$. A formaçã de poros persiste por alguns microsegundos incrementando a permeabilidade da membrana. Isto permite um intercâmbio de componen tes extra e intracelulares por difusão. O tamanho de molécula capaz de passar através da membrana depenáe da intensidade do campo elétrico e do tempo de tratamento (ZTMMERMANN, I982). Quanto maior intensidade e tempo de exposiça, maior será o tamanho de molécula que poderá passar; porén se eles excederem em muito os parâmetros requeridos para produzir a quebra da membrana a destruição da mesma e portanto da célula será irreversivel (ZIMMERMANN et alii, 1981). 
A frusão se produz ponque, devido ao campo elétrico, as moléculas lipidicas da membrana orientam-se nos poros abertos de maneira de formar uma ponte abrindo túneis. ES ta configuração é instável devido à grande curvatura da super ficie dos túneis e à grande tensão superficial das células. Des sa maneira forma-se uma célula esférica grande produzindo-se assim a fusão celular.

A técnica de eletrofusão tem sido aplicada na fusão de protoplastos de plantas (SENDA et alii, 1979; ZIMUER MANN et alii, 1980; ZIMMERMANN \& SCHEURICH, 1982; ZIMRERMANN, 1982), células de mamíferos (ZIMMERMANN \& VIENKEN, 1982) e Ij. possomos (BUSCHL et alii, 1982). Tin microrganisnos foi utilizada para a fusão de protoplastos de bactérias, Bacillus

thuringensis (BERG et alii, 1984); de leveduras, S.cerevisiae (WEBER et alii, 1981; HALFANN et alii, 1982; HALFANN et alii 1983; BERG et alii, 2984; SCHNETTLER \& ZIMHERMANN, 1985), Saccharomycopsis lipolytica (WEBER et alii, 1981; BERG et alii, 1984) e lodderomyces elongisporus (JACOB et alii, 1979) assim como na transferência de mitocôndrias em leveduras (HAL FMANN et alii, 1982) e transformação de B. thuringensis (BERG et alii, 1984). Porém, não foram encontradas referências sobre o uso da técnica de eletrofusão em fungos filamentosos. 
3. MATERIAL E METODOS

3.1 Linhagem Utilizada.

A Iinhagem utilizada de Humicola sp foi isolada de compostagem por CHAVES (1982) no Laboratório de Microbiologia do Departamento de Biologia Ceraz da Universidade re deral de viçosa.

3.2 Meios de Cultura Utilizados.

3.2.l Meio mínimo Sólido (MM)(PONTECORVO et alii,1953)

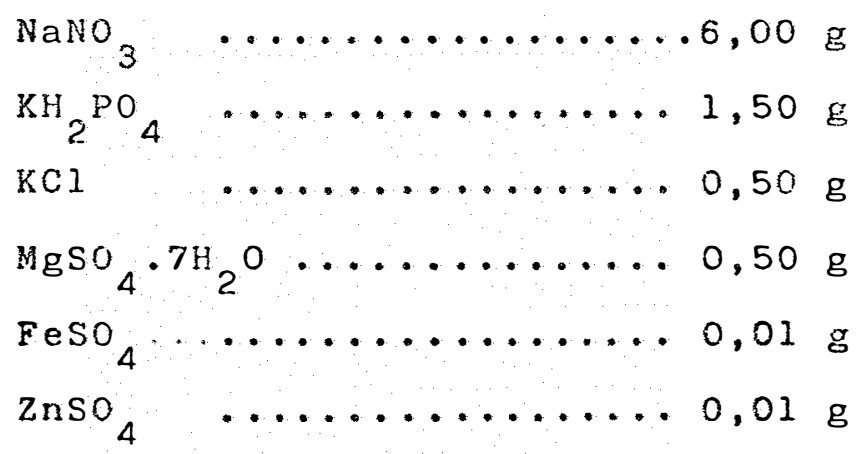




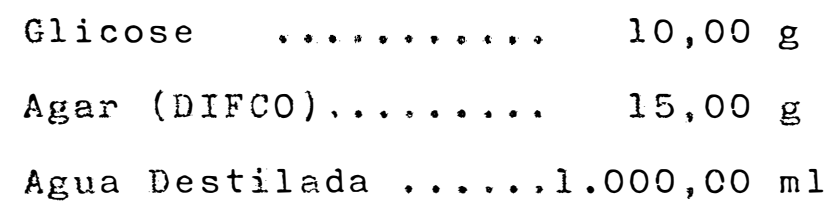

0 pH foi ajustado para $6,8 \mathrm{com} N a O H$ N.

3.2.2. Meio Completo Sólido (MC)(PONTECorvo et alii, 1953) modificado por AZEVEDO \& COSTA (1973). Ao meio mínimo sólido (item 3.2 .1 ) foram ài

cionados:

$$
\begin{aligned}
& \text { Peptona } \quad \ldots \ldots \ldots \ldots 2,00 \mathrm{~g} \\
& \text { Caseina Hidrolisada... 2,50 g } \\
& \text { Extrato de Levedura .. 0,50 g } \\
& \text { Soluçäo de Vitaminas.. 1,00 mi } \\
& \text { Solugão de Acidos Nuclejcos } \\
& \text { die Levedura ......... 1,00 } \mathrm{nI} \\
& 0 \mathrm{pH} \text { foi ajustado para } 6,8 \mathrm{com} \text { NaOH } 1 \mathrm{~N} \text {. }
\end{aligned}
$$

3.2.3 Meio Minimo $2 \times$ Concentrado.

Preparado segundo a composiçäo do $M M$ (item 3.2.1), onde cada componente foi adicionado em quantidade dobrada, com exceção da água.

3.2.4 Meio Completo $2 x$ Concentrado.

Preparado segundo a composição do MC (item 3.2.2), onde cada componente foi adicionado em quantidade do- 
brada, com exceção da água.

\subsubsection{Meio Mínimo Liquido.}

$$
\text { Preparado segundo a composição do MHH item }
$$

3.2.7) sem adicionar o ágar e sem glicose. Uma solução de gli cose $20 \%$ foj. preparada por separado, autoclavada a média atmósfera por 30 minutos e logo adicionada ao MM líquido na pro porção de $1: 20$.

3.2.6 Meio para crescimento de Micélio.

Ao meio mánimo íquido (item 3.2.5) foram adi... cionados $5,0 \mathrm{~g} / \mathrm{l}$ de extrato de levedura e $2,0 \mathrm{~g} / \mathrm{l}$ de caseina hidrolisada.

3.2.7 Meio Minimo para Humicola sp (MMH) (MACEDO, 1986)

No momento de uso, 5,0 $\mathrm{ml}$ das soluções de tiamina e biotina foram adicionados a $1.000,00 \mathrm{ml}$ de MM (item $3.2 .1)$ fundido.

3.2.8 Meio para Regeneraço de Protoplastos.

No momento de uso, o MC $2 x$ concentrado (item 3.2.4) foi diluido com a solução do estabilizador osmótico, $\mathrm{MgSO}_{4} 0,5 \mathrm{M}$ em tampão fosfato $0,02 \mathrm{M} \mathrm{pH} 5,6$, na proporção de $1: 1$. 
3.2.9 Meio para Visualização de halo de degradação de celulose.

$$
\begin{aligned}
& \text { } \mathrm{kei} \quad \ldots \ldots \ldots \ldots, 3,8 \mathrm{~g} \\
& \mathrm{~K}_{2} \mathrm{HPO}_{4} \ldots \ldots \ldots \ldots \ldots . \ldots 2,0 \mathrm{~g} \\
& \mathrm{MgSO}_{4} \cdot 7 \mathrm{H}_{2} \mathrm{O} \ldots \ldots \ldots \ldots, 0,1 \mathrm{~g} \\
& \left(\mathrm{NH}_{4}\right)_{2} \mathrm{SO}_{4} \ldots \ldots \ldots \ldots \ldots . . .1,0 \mathrm{~g} \\
& \text { Extrato de nalte..... } 0,6 \mathrm{~g} \\
& \text { Citrato de Sodio } \\
& \left(\mathrm{Na}_{3} \mathrm{C}_{6} \mathrm{H}_{5} \mathrm{O}_{7} \cdot \mathrm{H}_{2} \mathrm{O}\right) \ldots \ldots 2,94 \mathrm{~g} \\
& \text { Agar } \ldots \ldots \ldots \ldots \text { 15,00 g } \\
& \text { Água Destilada ....... } 000,00 \mathrm{ml}
\end{aligned}
$$

Este meio foi acrescentado de Celulose Ácida, preparada segundo TANSEY (1971), em concentraço de 10 g/l. O pH foi ajustado para $7,0 \mathrm{com} \mathrm{NaOH} 1 \mathrm{~N}$.

3.2.10 Mejo de Petterson para Produgão de Celulases (PETTERSON et alii, 1963).

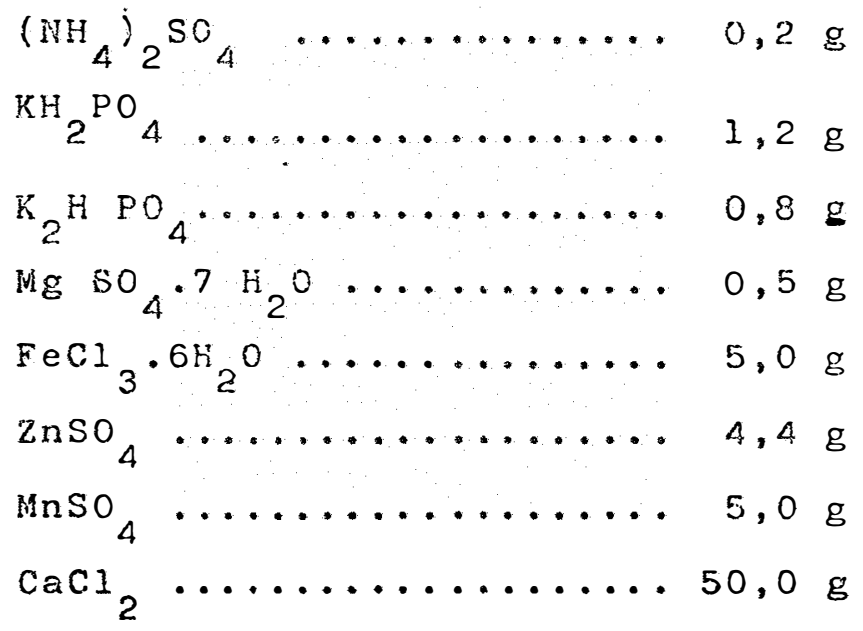


Extrato de Levedura

$(\mathrm{DIFCO}) \ldots \ldots \ldots \ldots \ldots, 0 \ldots \ldots$

Proteose-peptona

$(D I F C O) \quad \ldots \ldots \ldots \ldots \ldots \ldots \ldots \ldots \ldots, 0 \ldots$

Celulose Microcristalina. $20,0 \mathrm{~g}$

Água Destilada ........ $1.000,0 \mathrm{ml}$

O pH foi ajustado para 5,8 com $\mathrm{H}_{3} \mathrm{PO}_{4} 2 \mathrm{~N}$.

3.2.11 Meio E para Produç̃a de Celulases.

Preparado segurido a composicăo do meio para vi sualização do halo de degradação de celujose (item 3.2 .9 ) com a exceção da celulose ácida ter sido substituida por celulose microcristalina e sem adicionar agar.

3.2.12 Meio para Mutantes Desreprimidos.

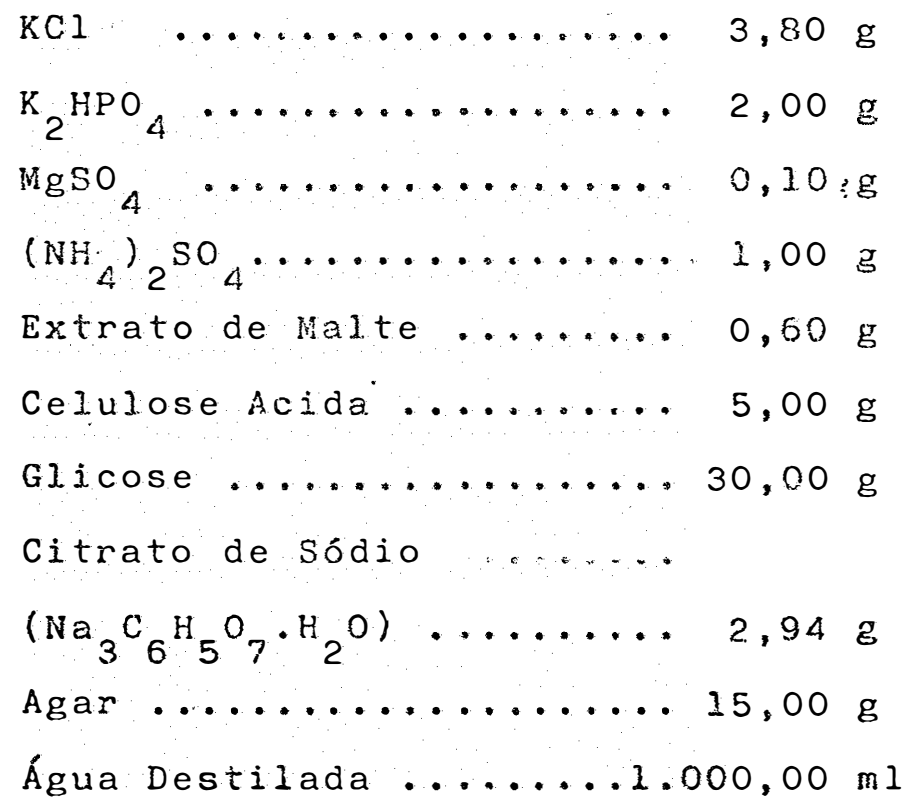


A celulose ácida foi preparada segundo TANSEY (1971). O pH foi ajustado para 7,O com NaOH $1 \mathrm{~N}$.

\subsubsection{Meios com 2-Deoxiglicose.}

No meio completo (item 3.2.2) foi subsituida a glicose pela 2-Deoxjglicose e no meio E ( item 3.2.11) foi adicionado $1 \%$ de 2-Deoxiglicose.

3.3. Soluções Utilizadas.

3.3.1 Solụão de Tweer 80 .

$$
\begin{aligned}
& \text { íween } 80 \ldots \ldots \ldots \ldots \ldots \ldots . \ldots 1 \mathrm{ml} \\
& \text { Água Destilada } \ldots \ldots \ldots 00 \mathrm{ml} \\
& \text { A soluçäo foidistribuida em aliquotas de } 2,5
\end{aligned}
$$

ml, para tubos de ensajo.

3.3.2 Solução Salina $(0,85 \%)$.

$$
\begin{aligned}
& \mathrm{NaCl} \quad \ldots \ldots \ldots \ldots \ldots . \ldots .68 \mathrm{~g} \\
& \text { Água Destilada .........000 ml } \\
& \text { A solução fói distribuida em frascos com tampa }
\end{aligned}
$$

de rosca com $9 \mathrm{ml}$ cada um.

3.3.3 Solução de Vitaminas (PONTECORVo et alii, 1953) modifica do por (AZEVEDO \& COSTA, 1973)

Acido Nicotínico .........100,0 mg

Acido p-aminobenzóico ..... 10,0 mg 


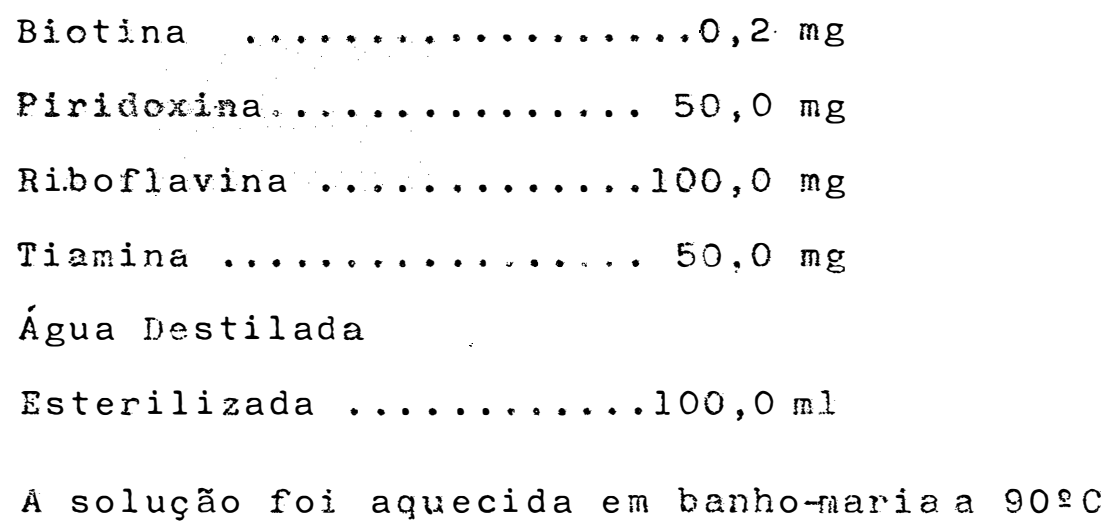
co escuro, no refrigerador a $49 \mathrm{C}$, sob clorofórmio. 
3.3.5 Solução de Caseina Hidrolisada.

Caseina Hidrolisada .......100,0 mg

Agua destilada

Esterilizada ............ 10,0 $\mathrm{ml}$

A solução foi aquecida em banho-maria a $90 \circ \mathrm{C}$ por 20 minutos e conservada em refrigerador a $49 \mathrm{C}$.

3.3.6 Solução de Extrato de Levedura.

Extrato de Levedura ........100,0 mg

Agua destilada

Esterilizada .................. $0 \mathrm{ml}$

A solução foi aquecida em banho-maria a $900 \mathrm{C}$ por 20 minutos e conservada em frasco escuro no refrigerador a $4 \cong \mathrm{C}$.

3.3.7 Soluções de Aminoácj.dos para Caracterização de Mutantes Auxotróficos.

Soluções dos 20 aminoácidos empregados (ácido aspártico, ácido glutâmico, alanina, arginina, asparagina,cis teina, cistina, fenil-alanina, gicina, glutamina, histidina, leucina, lisina, metionina, proina, serina, tirosina, treoni na, triptófano e valinal foram preparadas em concentração de 1\%; $100,00 \mathrm{mg}$ de cada aminoácido foram colocados em frascos com 10,0 ml de água destilada esterilizada. Os frascos foram aqueciòos em banho-maria a 80 QC por 30 minutos e, para facili tar a dissolução dos aminoácidos, foi adicionada uma gota de 
HCl I N. As soluçōes foram conservadas em refrigerador a $49 \mathrm{C}$.

3.3 .8 Solução de $\mathrm{NaOH} 1 \mathrm{~N}$.

$$
\begin{aligned}
& \text { NaOH } \ldots \ldots \ldots \ldots . . .4,0 \mathrm{~g} \\
& \text { Agua destilada } \ldots . .100,0 \mathrm{ml} \\
& \text { A solução foi conservada a temperatura ambiente. }
\end{aligned}
$$

3.3.9 Solução de HCl $1 \mathrm{~N}$.

$$
\mathrm{HCl} \ldots \ldots . . . .8,5,1
$$

Água Destilada ....100,0 m?

A soluçăo foi conservada a temperatura ambiente.

3.3.10 Tampão Eosfato 0,02 M pH 5,6.

$$
\begin{aligned}
& \text { Soluça A (NaH } \left.{ }_{2} \mathrm{PO}_{4}{ }^{\circ} \mathrm{H}_{2} \mathrm{O} O, 02 \mathrm{M}\right) \\
& \mathrm{NaH}_{2} \mathrm{PO}_{4} \cdot \mathrm{H}_{2} \mathrm{O} \ldots \ldots \ldots 2,76 \mathrm{~g} \\
& \text { Água Destilada .... }
\end{aligned}
$$

Solução $\mathrm{B}\left(\mathrm{Na}_{2} \mathrm{FiFO}_{4} \cdot 7 \mathrm{H}_{2} \mathrm{O} 0,02 \mathrm{M}\right)$

$\mathrm{Na}_{2} \mathrm{HPO}_{4} .7 \mathrm{H}_{2} \mathrm{O} \ldots \ldots 5,36 \mathrm{~g}$

Água Destiliada ....1000,00 ml

Ambas soluções foram conservadas, separadamente no refrigerador. O tampão fosfato 0,02 M pH 5,6 foi preparado no momento do uso, adicionando-se a solução B em $920 \mathrm{ml}$ de solução A até atingir pH 5,6 . 
3.3.11 Tampão Fosfato pH 7,0.

Solução A

$\mathrm{Na}_{2} \mathrm{HPO}_{4} \cdot 12 \quad \mathrm{H}_{2} \mathrm{O} \quad \ldots \ldots \ldots \ldots 3,73 \mathrm{E}$

Água Destilada ..........1000,00 ml

Solução B

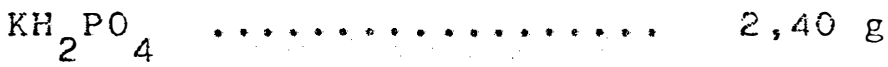

Água Destilada ..........1000,00 $\mathrm{ml}$

A solução A foi misturada com a solução $B$ na proporcão $7: 3$, O $\mathrm{pH}$ foi ajustado para 7,0 e a mistura conser vada em refrigerador a 400 .

3.3.12 Tampão Citrato $0,05 \mathrm{MpH} 4,8$.

Solução A (Ácido Citrico $0,05 \mathrm{M}$ )

Ácido Citrico

Monohidratado ........ 10,505 g

Água Destilada ........... 1.000,000 ml

Solução B (Citrato de Sodio 0,05 M)

Citrato de Sódio ....... 14,705 g

Água Destilada ........... $1.000,000 \mathrm{ml}$

A solução A foi adicionada a $500,0 \mathrm{ml}$ da solução B até pH 4,8 e a mistura conservada em rafrigerador a $\triangle 2 C$. 
3.3.13 Solução de Albumina 5\% (ROBINOW \& CATEN,1969)

Clara de ovo ......... 5, 0 nl

Água destillada

sterilizada ......... $95,0 \mathrm{ml}$

A mistura foi homogeneizada, filtrada e conser vada em frasco escuro no refrigerador.

3.3.14 Solução Estoque de Giemsa (BECAK \& PAULETE, $1976)$

Giemsa em pó......... 3,8 g

Metanol $\ldots \ldots \ldots \ldots 250,0 \mathrm{ml}$

Glicerina $\ldots \ldots \ldots \ldots 250,0 \mathrm{ml}$

As substancias foran misturadas pela ordem e a mistura foi conservada en vidro de tampa esmexilhada por 72 horas antes de ser utilizada. Esta solução foì conservada á temperatura ambiente.

3.3.15 Solução Corante de HCl Giemsa (FURTADO,1968).

Solução estoque de Giemsa ... 1,0 ml

Solução tampão fosînato

pH $7,0 \ldots \ldots \ldots \ldots \ldots, 0 \ldots \ldots$

As duas soluções foram misturadas no momento

de uso. 


\subsubsection{Soluçöes de Álcool Etilico.}

As soluções foran preparadas nas concentraçōes de 95,70 e 50\% diluindo-se o álcool com água destiliada e to-. ram conservadas a temperatura ambiente.

$$
\text { 3.2.17 Solução de Eixação. }
$$

No momento do uso, foi preparada uma solugăo de alcool etilico absoluto, ácido acético glacial e ácido la tico na proporcão $6: 1: 1$.

3.3.18 Reagente Acido Dinitro Salicilico (DNS). Ácido 3,5-dinitrosalicilico .... 5, 3 $\mathrm{NaOH} \quad \ldots \ldots \ldots \ldots \ldots \ldots \ldots \ldots \ldots \ldots, \eta \ldots \ldots$ Água destilada ...........7.708,0 mI

Os reagentes acima foram dissolvidos Ientamen... te e em seguida foram adicionados:

Tantarato de sódio

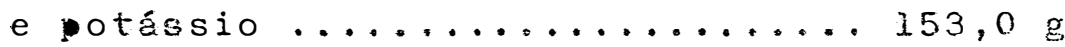
Fenol (a $509 \mathrm{c}) \ldots \ldots \ldots \ldots \ldots, 8 \ldots \ldots$ Metabissulfito de sódio......... 4, 2 g A mistura foi conservada em frasco escuro á temperatura ambiente. 
3.3.19 Soluçăo de PBS.

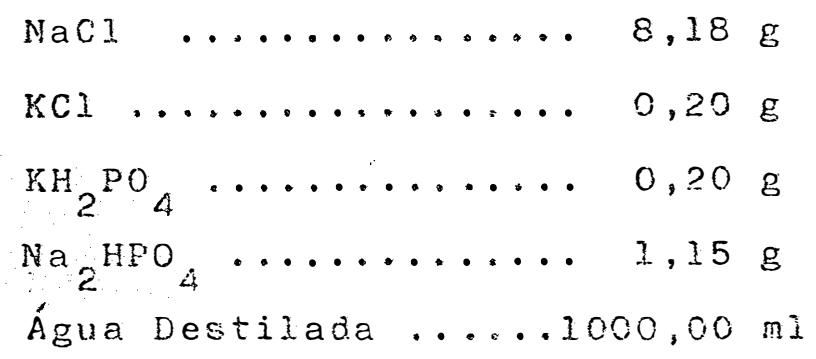

3.3.20 Solução Estoque de Tiamina.

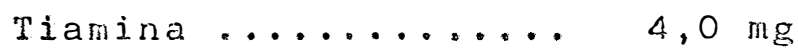

Água Destilada

Esterilizada,..... $10,0 \mathrm{ml}$

A solução foi aquecidà em banho-maria a $900 \mathrm{C}$ por 20 minutos e conservada en refrigerador.

3.3.21 Soluço Estoque de Biotina.

Biotina ......... 4,0 mg

Agua Destilada

Esterilizada $\ldots \ldots . . .10,0 \mathrm{ml}$

A soluça foi aquecida en banro-maria a $900 \mathrm{C}$ por 20 minutos e corservada em refrigerador.

3.3.22 Soluçõos de Tiamina e Biotina.

Tiamina ..... $0 \mathrm{mi}$ da solução estoque de tiamina em $9,0 \mathrm{ml}$ de água Desti lada esterilizada. 


\section{Biotina $\ldots . . .1,0 \mathrm{ml}$ da solugão estoque de biotina em $9,0 \mathrm{ml}$ de água des- tilada esterilizada.}

As soluções foram preparadas no memento de uso.

3.3.23 Soluçäo de $\mathrm{MgSO}_{4} 0,5 \mathrm{~m}$ pH 5,6 .

$\mathrm{MgSO}_{4} \cdot 7 \mathrm{H}_{2} \mathrm{O} \quad \ldots \ldots \ldots \ldots \ldots 23,24 \mathrm{~g}$

Soluçäo A

(tampão fosfato 0,02 in

$\mathrm{pH}, 5,6) \ldots \ldots \ldots \ldots \ldots, 500,00 \mathrm{ml}$

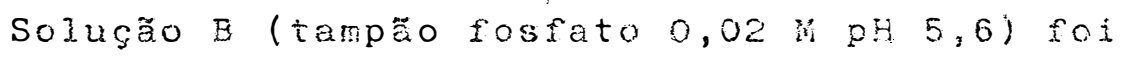
adicionada até $\mathrm{pH} 5,6$ e o volume completado para $1.000,00 \mathrm{mz}$ com tampão fosfato $0,02 \mathrm{M} \mathrm{pH} 5,5$ (iten 3.3 .10$)$.

3.3.24 Soluçäo de Sacarose $0,8 \mathrm{k}$ pH 5,6 e pH 7,0 .

Sacarose ............. $27,38 g$

Água Destilada ...... 100,00 ml.

O pH foi ajustado para 5,6 \& 7,0 com HCl ou

NaOH segundo o caso.

3.3.25 Solução de Sorbitol $0,8 \mathrm{M} \mathrm{pH}, 0$

(SCHNETTLER \& ZIMMERMANN, 2985 modificado).

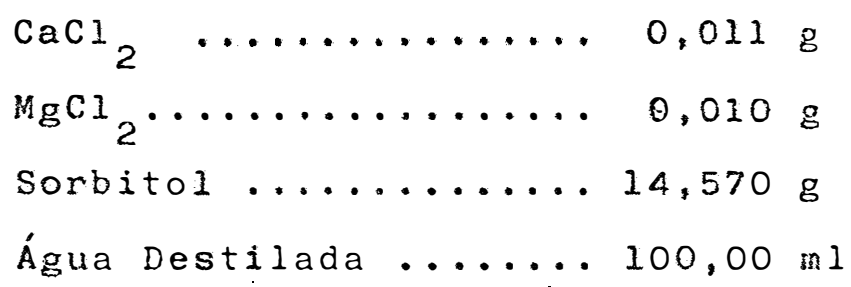


0 pH Soi ajustado para 7,0 com NaOH.

3.3.26 Solução de Sorbitol 1,2 $\mathrm{NH} 7,0$ (Schnettler e Zimmermann, 1985 modificado).

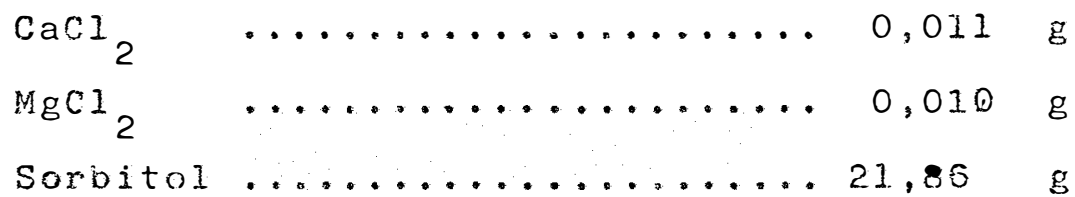

Agua Destilada ....................

O pH foi ajustado para 7,0 com NaOH.

3.3.27 Solução de Sorbitol 0,8 M pH 7,0 com PEG $20 \%$ e $40 \%$.

As soluços foram prepanadas segundo o item 3.3 . 25 adicionada de PEG $(6.000)$ nas concentraçôs de $20 \%$ e $40 \%$.

3.3.28 Soluça de Benlate.

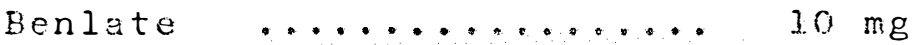

Agua Destilada Esterilizada. $200 \mathrm{ml}$

Primeiramente o benlate foi dissolvido em una gota de acetona, logo adicionou- se a ägua. Esta solução foi fervida em banhoma ria durante 20 minutos e adicionada no meio de cultivo nas concentraçoes ensaiadas. A solução foi mantida. no refrigerador.

3.3.29 Solução de Acriflavina.

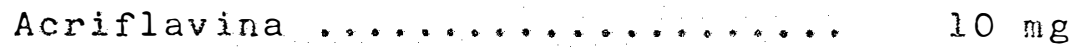

$$
\begin{aligned}
& \text { Agua Destilada Esterilizada..... } 100 \mathrm{ml}
\end{aligned}
$$

Esta soluço foi fervida em banho-maria durante 20 minutos e adicionada ao meio de cultivo nas concentracos ensaiadas. A solução foi mantida em frasco escuro no refnigerador. 
3.3.30 Solugâo de Cristal yioleta.

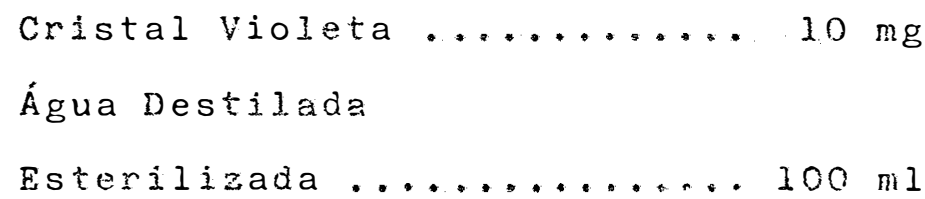

Esta solução foi fervidaem oanho-maria durante 20 minutos e adicionada ao meio de cultivo nas concentrações ensaiadas. A solução foi mantida em frasco escuro no refrigerador.

3.3.31 Tampäo Tris HCl O,I M pH 8 .

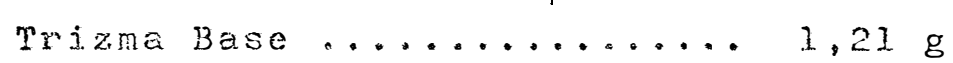

Água bestilade ...........100,00 ml

o pH foi ajustado para pH 8 com HCl.

3.3.32 Vermelno Congo 0,025\% pH 8.

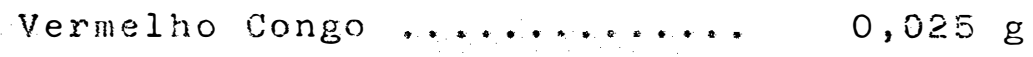

Tampão tris HCI $0, I M p H ~ \& \quad 100,000 \mathrm{ml}$

3.3.33 NaCl $0,5 \mathrm{MpH} 8$.

$\operatorname{NaCl} \ldots \ldots \ldots \ldots \ldots \ldots \ldots \ldots, 3,42 g$

Tampäo Tris HCl 0,1 M pH $8 \ldots 100,000 \mathrm{ml}$

3.3.34 Esterilização e Conservação.

Exceto quando expressamente mencionado os materiais utilizados foram esterilizados em autoclave a l2l90 
durante 15 minutos e conservados em refrigerador.

\section{3 .35 Incubação.}

Exceto quando expressamente mencionado, a cultu ra empregada neste trabalho foi crescida em placas com Meio Completo por 7 dias a $420 \mathrm{C}$.

3.4 Técnica semiquantitativa de avaliaça da produça de celulases em Humicola sp.

Para os estudos de melhoranento genetico reaji zados neste trabalho, visando incrementar a producão de enzimas celuloliticas em Humicola sp, tornou-se necessario o cesenvolvimento de una técnica para quantificar de modo simples e répidamente a produção de celulases, Desta forma poderia-se isolar mutentes de alta produçäo destas enzimas, permitincà as sim o melhoramento genético deste s̃ungo.

\subsubsection{Meios de Cultivo ensaiados.}

A partir do meio de cultivo utilizado por CHA... VES (1982), que não promove a formacão de halo de degradaçäo de celulose foi desenvolvido um meio que permite a visualização de halo e quantificação da capacidade ceiulolítica em Humicola sp pela mediçäo do diametro do halo formado. A compo sição (g/l) desse meio é a seguinte: $\mathrm{KCl}_{3} 3,8 ; \mathrm{K}_{2} \mathrm{HPO}_{4} 2,0$; $\mathrm{MgSO}_{4} \cdot 7 \mathrm{H}_{2} \mathrm{O} 0,1 ;\left(\mathrm{NH}_{4}\right)_{2} \mathrm{SO}_{4} 1,0 ;$ Extrato de Malte ou de Levedura 0,6; Celulose Acida 10,0; Agar 15,0 e Citrato de Sódio 
5 ou $10 \mathrm{mM}$. Deste meio bésico derivaram os quatro meios utili zados no presente trabalho, de acordo com a quantidade de citrato de sódio usada e emprego de extrato de malte au de leve dura: Meio 1: Extrato de levedura; Citrato de Sódio $5 \mathrm{mM}$. Meio 2: Extrato de Levedura; Citrato de Sódio $10 \mathrm{mM}$. Meio 3 : Extra to de Malte; Citrato de Sódio 5mM. Meio 4: Extrato de Malte; Citrato de Sódio $10 \mathrm{~m}$.

3.4.2, Condiçōes de Cultivo: Incculação, Incubacăo e Choque térmico.

Foram inoculadas cinoo colonias por placa e es tas mantidas em incubaça durante $3,5,7$ e 10 dias a $420 \mathrm{C}$. hpós a incubação o material foi submetido a um choque térmico de 5000 durante 16 horas. A seguir foi medido o dianetso. da colônia, observada a presença de haio e deterninado o índice de atividade enzimática (IAE= diâmetro halo/diânetro cojônia).

\subsubsection{Técnica de coloração.}

Foi ensaiado o processo de coloraçäo descrito por TEATHER \& WOOD (1982) utilizando vernejho congo além de uma modificação desse processio. Neste caso, após a incubação e choque térmico, foram utilizados $10 \mathrm{ml}$ por placa de solução de vermelho congo $(0,025 \%)$ em tampão Tris HCI 0,1 M 3.3.32). Após 30 minutos, retirou-se essa solução e lavou-se à placa com 5 a $6 \mathrm{ml}$ de NaCl $0,5 \mathrm{M}$ em tampão Tris HCl 0,1 MH 8 (item 3.3 .33 ) durante 5 minutos. 
3.5 Frotoplastos de Humicola sp.

\subsubsection{Obterção de Protoplastos.}

Os protoplastos foram obtidos a partir de micé lio dado que os conídios de Humicola sp são multinucleadosffig. 7b, 7d). Foi utilizada a técnica descrita por PEBERDY (1979) com modificações sugeridas por MACEDO \& AZEVEDO (1985). Una suspensão de conídios de Humicola sp foi preparada em soluçấo de Tween 80 (item 3.3.1) e o número de conídios por miljitiro foi determinado com o auxilio da câmara de Neubauer. Com esta suspensão inoculou-se um erlenmeyer de $125 \mathrm{ml}$ contencio 50 ml de meio para produçäo de micélio (iten 3.2.6) previamente esterilizado, dando uma concentração final de $10^{5}$ conjíasinl de meio. Este ioi mantido em agitador rotatóric ( $150 \mathrm{rpm})$ a 40ㄷ durante 20 horas. O micélio produzido foi riltrado en fu nil de Buchner com o auxilio de bomba de vácuo e lavado con o estabilizador osmótico $\mathrm{MgSO}_{4} 0,5 \mathrm{M}$ em tampão fos lato $0,02 \mathrm{~m}$ pH 5,6 (item 3.3.23). O peso úmido do mesmo foi deterninado em balanga analitica. A protoplastizaça foi feita adioionando a este micélio um complexo de enzima litica (HAMLIN et alii 1981) e em presenca do estabilizador osmótico MgSO 0,5 Ma proporção de $50 \mathrm{mg}$ de micélio: $5 \mathrm{mg}$ de enzima lítica (50\% de celulase CP e 50\% de Novozyn 234): 1, O ml do estabilizador os mótico. Esta mistura foi mantida en agitador recíproco (120rpm) durante 3 horas. Em seguida, uma gota da suspensão fol colocada entre lâmina e laminula e, com o auxílio de um microscópio pôde-se : observar a presença de protoplas 
tos. Confirmada a presenca dos mesmos, a suspensäo foj centri fugada por 30 segundos a $500 \mathrm{rpm}$ e o sobrenadante retirado centrifugado por $10 \mathrm{minutos}$ a $4000 \mathrm{rpm}$. 0 sobrenadante foi desprezado e o precipitado ressuspenso no estabilizador osmótico e novamente centrifuga por 10 minutos a 4000 rpm. Fsta operação foi repetida mais duas vezes. Os protoplastos obtidos foram ressuspensos em volume conhecido do estabilizador osmó.. tico e, com o auxilio da câmara de Neubauer, foi determinado o número de protoplastos por mililitro de suspensão.

3.5.2 Regeneração de Protoplastos.

Com os protopiastos obtidos e uma ver connecido o número de protoplastos por mililitro de suspensãocono descrito no item 3.5.1 foram realizadas diluiços apropriadas tambén no estabilizador osmótjco. Em seguida, 1 ml dessas à... luicâes foi semeado por"pour plate" em MC; MC MgSO 0,25 Me MC MgSO $0 ., 5 \mathrm{~m}$. A metade das placas foi incubada a $420 \mathrm{C}$ duran te 7 dias e a outra metade a $280 \mathrm{C}$ durante 24 horas e logo transferidas a $420 \mathrm{C}$ até completar 7 dias de incubação. A rege noração foi constatada pelo crescimento de colônias no Motestabilizador enquanto a presenca de células näo protoplastiza das foi constatada pelo crescimento de colonias no MC.

A porcentagem de regenerạ̧ăo foi calculada aplicando a seguinte fórmula:

$$
\% \text { regeneração }=\frac{-B-A}{C} \times 100 \text {; }
$$


onde: A : No de colônias crescidas em MC.

B : No de colônias crescidas em MCtestabilizador.

C : Ne de protoplastosiml da suspensão.

3.5.3 Curva de Sobrevivência de protoplastos á luz Ultravioleta (UV).

Foi utilizada uma lâmpada de Iuz ultravioleta Mineralight (Modelo NoP-52) de $2537 \AA$, previamente estabiliza da durante 15 minutos. O material a ser irradiado foi colocado a uma distancia de $19,2 \mathrm{~cm}$ da fonte de irradiaça, a dose de UV foi de 5 joules $/ \mathrm{m}^{2} / \mathrm{seg}$.

A suspensão de protoplastos a ser irradiada foi obtida e a sua concentração estimada segundo o item 3.5.1. 0s tempos de exposição da suspensão á luz UV foram de 0, I0, 20 , 40, e 80 segundos correspondendo doses de 0,50,100,200 400 joules. Para cada un desses tempos, foram f́eitlas diluições apropriadas em $\mathrm{MgSO}_{4} 0,5 \mathrm{M}$ em tampão fosfato $0,02 \mathrm{M}$ pH $5,6$. Em seguida, I ml de cada diluiçã foi semeado por "pour plate" em MC MgSO $40,25 \mathrm{M}$. As placas foram incubadas a $280 \mathrm{C}$ durante 24 horas na ausência total de luz e logo transferidas para 42 o c até completar 7 dias de incubaçäo. O tempo zero correspondente a colônias näo irradiadas foj considerado o $100 \%$ ùe sobrevivência.

3.5.4. Técnica do Doador Morto.

A suspensão de protoplastos foi obtida e a sua concentração deternirada segundo o descrito no item 3.5.2. 
Uma vez obtidos e contados, os protoplastos foram transferidos para tubos de ensaio de inox e coiocados em banho-maria onde foram submetidos a diferentes tratanentos témicos. A seguir eles foram semeados em MC MgSO 0,25 M a $280 \mathrm{C}$ durante 24 horas $e$ de aj. transferidos a $420 \mathrm{C}$ até completar ? dias de incubaç

3.5.5 Liberação de protoplastos a partir do micélio. A procura da obtençấo de protoplastos uninuclea dos, de interesse para estudos genéticos e de melnoramento, mo tivou o estudo do processo de liberacão de protoplastos a pantir do micélio. Com esse fin foran obtidos protoplastos, "como descrito no item 3.5.I, com diferentes tempos de tratamento en zimátic., variando de 30 minutos até 3 horas. Para cada un deles fol deteriniado o núnero de protoplastos obtidos por nililitro de suspeneão e calculada a frequência de regenexaça (itens 3.5.1 e 3.5.2). Tambén foi realizada a coloraça de pro toplastos, detexminada a frequência do númexo de núcieos dos mesmos e medido o diânetro dos protoplastos de 30 minutos e de 3 horas.

3.5.5.1 Coloração de Conídios e Procopiastos (TANAkA et a1ii,1979) $A$ coloração de conídios assim como de protoplas tos constou dos seguintes passos:

- Montagem da lamínula: colocou-so sobre lamínula uma gota de solução de Albumina-glicerina e uma gota da suspeñsão de coinidios ou protoplastos Misturarammseambas gotas e secou-se por discreto aquecimento. 
- Fixação: deixou-se a laminula como material na soluço fixadora (item 3.3.17) durante 30 minutos.

- Hidratação: o material foi tratado com álcool 95\% por 5 a 10 minutos; alcool. $70 \%$ (manimo 2 horas) e lavou-se ligeira mente o material em 3 águas destiladas diferentes,

- Hidrólise: foi feita em HCl $1 \mathrm{~N}$ en banho-maria a $60 \mathrm{Co}$ Conidios foram tratados por 3 a 10 minutos e os protoplastos 1 minuto.

- Lavagem: foram feitas três passagens em água destilada, por 10 ininutos cada uma.

- Coloração: adicionou-se o corante fiCl-Giemsa (iten 3.3.J.5) sobre a laminula. Dejxou-se por $30^{\prime}$ minutos tanto no caso de conidios como de protoplastos.

- Lavagem: roran feitas três passagens por tampa fosfato (item 3.3 .11 i.

- Montagem: colocou-se a Iaminula sobre a lamina e observouse em microscópio öptico.

\subsubsection{Frequência do Número de Núcleos.}

A partir das laminas coradas (item 3.5.5.1) e por observaço ao microscópio óptico foi contado o número se núcleos de protoplastos de cada tempo de tratamerito enzimático ensaiado. Com esses dados determinou-se a frequência do nú mero de núcleos em protoplastos de Humicola $\mathrm{sp}$.

3.5.5.3 Diâmetro dos Protoplastos.

A partir de suspensões de protoplastos à îres- 
co, no estabilizador osmótico (item 3.3.23), e com o auxilio de um micrômetro ocular e microscópio foi determinado o dia metro de protoplastos obtidos com 30 minutos e 3 horas de tratamento enzimático

3.6 Marcas Genéticas.

3.6.1 Obtenção de Mutentes.

Uma suspensão de protoplastos contendo cerca de $10^{7}$ células/ml, obtidos nas condiçós descritas no item 3. 5.1. foi preparada em $\mathrm{MgSO}_{4} 0,5 \mathrm{M}$ em tampzo fosfato $0,02 \mathrm{MH}$ 5,6. A suspensão colocada em placa de petri vazia foi irradia da com luz UV, sob leve agitação, nas condiçöes de tempo e distância determinadas no item 3.5 .3 , a fim de se obter cerca de 5\% de sobrevivência. Após a irradiação, a suspensão de pro toplastos foi convenientemente diluida e l ml semeado por "pour plate" em placa com MC MgSO $0,25 \mathrm{M}$ pH 5,6. A regeneraçäo rea lizou-se nass condições descritas no jtem 3.5.2. Este método foi utilizado para a obtença de mutantes morfológicos desrepnimidos, resistentes e auxotróficos.

\subsubsection{Mutantes Morfológicos.}

Após a irradiação e regeneração e a partir das placas com $\mathrm{MC} \mathrm{MgSO}_{4} 0,25 \mathrm{M}$ (item 3.6 .1$)$ isolaram-se as colônias que apresentaram alteraçoses morfológicas. As mesmas fow ram transferidas para placas com MC e incubadas a $429 \mathrm{C}$ durante 7 dias. A caracterização destes mutantes foi feita comparando-se, mediante observação direta, especialmente o aspecto 
morfologico, cor, etc. das colonias alteraàas em relaçầ à li nhagem selvagem utilizada como controle.

\subsection{1:2 Mutantes Desreprimidos.}

Depois da irradiaçăo e regeneração, as colônias crescidas no MC MgSO 0,25 M foram ensaiadas em meio para mutantes desreprimidos (item 3.2.12). Foran inoculados 5 possín veis mutantes por placa e incubados a $420 \mathrm{C}$ durante 5 dias. A seguir aplicou-se un choque térmico de $500 \mathrm{c}$ durante 15 horas e procuroumse colonias que apresentaram degradagâa ca celulose. As colonias isoladas nesta primeira fase foram submetidas a um segundo teste, onde foram incubiadas a 4290 somente duran te 3 dias, selecionando-se as colônjas que rovamente apresentarain uma zona clara de degradaço da celulose.

\subsubsection{Mutantes Resistentes.}

Foram realizados testes para a obtengẩo de mutantes resistentes ao fungicicia Benlate; ao antimetabolito 2Deoxiglicose e aos corantes Acriflavina e Cristal Violeta.

\subsection{Resistência a Benlate.}

A determinação do nível de resistência da linhagem selvagem a este fungicida foi realizada em ciois experimentos, mediante a utilização de diferentes concentrações de Benlate em MC. Em um primeiro experimento utilizaram-se as concentrações de 0,$0 ; 0,1 ; 0,2 ; 0,3 ; 0,4 ; 0,5 ; 0,6 ; 0,7$; 0,$8 ; 0,9$ e $1,0 \mu g$ de Benlate/ml de MC. Foram feitas duas pla cas para cada concentração com 4 inoculações por placa.o diâ 
metro das colonias foi medido com dois dias de incubação na temperatura ótima de crescimento do fungo (420C). Devido aos resultados obtidos, em um segundo experimento foi estudada a resistência para as concentrações: 0,$00 ; 0,10 ; 0,20 ; 0,30$; 0,$32 ; 0,34 ; 0,36 ; 0,38$ e $0,40 \mu g / m 1$. Foram preparadas duas placas para cada concentragăo, inoculando, com ajuda de um fio de platina umidecido emi uma suspensão de conídios em Twe en 80, um ponto no centro de cada placa. O diâmetro das colonias foi medido com 24,48 e 72 horas de ircubagäo a $420 \mathrm{C}$.

0 isolamento de mutantes resistentes foi reali zado a partir de una suspensão de conídios da linhagem sejvagem, semeando $10^{6}$ conídios por placa, de concentração 0,4 pgjml. A seguir realizou-se um teste para aumento de resisten cia no qual de duas colônias resistentes a $\bullet, 4 \mu g$ de Benlatel $m l$ de MC (colonias A $E$ B) fonam preparadas suspensỏes de coní dios semeando $10^{6}$ coníaios em cada placa das seguintes concen trações: 0,$5 ; 0,7 ; 1,0$ e 1,2,ig de Benlate/ml de MC.

3.6.1.3.2 Resistência a 2-Deoxiglicose.

A determinação do nível de resistência da linhagem selvagem a este antimetabólito (2DG) foi realizada en 2 etapas. Na primeira etapa para cada meio foram semeadas duas placas de Petri com $10^{5}$ conídios de Humicola sp selvagem por placa e incubadas durante 6 dias a $420 \mathrm{C}$. Os meios utilizados foram os seguintes: $M C-2 D G: M C$ aonde a glicose foi substituida pela 2DG como única fonte de C; o Meio $E$ (item 3.2.11) para produção de celuzases (ME celulose $1 \%$ ) e o Meio E-2DG: Meio E 
adiciorado de 2DG (Meio E com celulose $(1 \%)+2 D G(1 \%)$ ). Na segunda etapa, a partir das colonias crescidas no Meio E-2DG foram inoculadas 2 placas, com 5 pontos cada uma, com os seguintes meios: Meio E-2DG; MC-2DG e MC. O Humicola sp selva.gem foi novamente ensaiado em Meio E-2DG. Todas as placas fom ram incubadas a $429 \mathrm{C}$ durante 5 dias.

\subsection{Resistência a Corantes.}

O Humicola ep selvagem foi submetido a Acriflavina e Cristal violeta. Para cada concentração ensaiada foram preparadas duas placas por inóculo, com um ponto cada una e uma placa por semeadura, com cerca de $10^{6}$ conídios/placa.

\subsubsection{Nutantes Auxotróficos.}

As colônias crescidas em MC Mgso $4,25 \mathrm{M}$, obtidas a partir da irradiação dos protoplastos, foram transíridas para placas de $\mathrm{MMH}$ em disposiça correspondente ao replicador de 26 pontos (AZEVEDo et alii, 1976) e incubadas a 420 C. Após 24-48 horas foi realizado o isolamento dos possíveis mutantes. A partir de cada un dos locais correspondentes a um inóculo não crescido retiroumse um bloco de agar contendo o inóculo, o mesmo foi transferido para placa con MC e incubado a $42 \circ \mathrm{C}$ durante 7 dias. Conídios dessas colônias foram transferidos para as placas de caracterização. A caracterização foi feita mediante inoculação e por semeadura. Por inoculação foram ensaiados 5 mutantes por placa, colocando-se em cada placa um requisito nutricional diferente. Os meios e re- 
cuseitos nutricionais utilizados na pirmeiro fase de caracterização foram: MMH + Caseina Hidrolisada; MMH + Ac.Nucleicos; $M M H+V i t a m i n a s ; M M H+E x t r a t o$ de Levedura e as placas contro. le MC e MMH, todos com duas repetiçoses. Por semeadura foram preparadas 6 placas para cada mutante, em cada uma delas semeou-se $l \mathrm{ml}$ de uma suspensão de conídios com aproximadamente $10^{6}$ conídios/ml. Após 24 horas de incubaçăo a 42002 placas de MMH foram divididas en 4 quadrantes. Caca quadrante recebeu $0,05 \mathrm{ml}$ de um requisito nutricional diferente, sendo dispostos os 4 requisitos em cada uma das duas placas ( 1 ig. I). Assim utilizaram-se duas placas de cada um dos seguintes mejos $M M H+o s 4$ requjsitos nutricionais; MMH e MC. Após $24-48$ how ras de incubaça foram observadas as placas elou quadrantes em que houve crescimento.Assim de acordo com a desiciancia expressada pelos mutantes, foi feita a segunca rase da caracterização com os requisitos nutricionais ensaiados indivioual mente.

Uma vez caracterizados os mutantes auxotróín cos e conhecida a resistência natural do fungo selvagem benlate, acriflavina e ao cristal violeta foi estudada a resistência dos mutantes auxotrósicos a estes compostos em MC., aos efeitos da introdução de uma segunda marca genética nes ses isolados. Para isso realizou-se um teste em placas de concentrações conhecidas e placas em gradiente, os isolados auxotrófico-resistentes crescidos nestas placas repicaram-se para um segundo teste de resistência a esses compostos. Também foi estudada a resistência desses isolados em MMH visanço seu uso em fusão de protoplastos. 


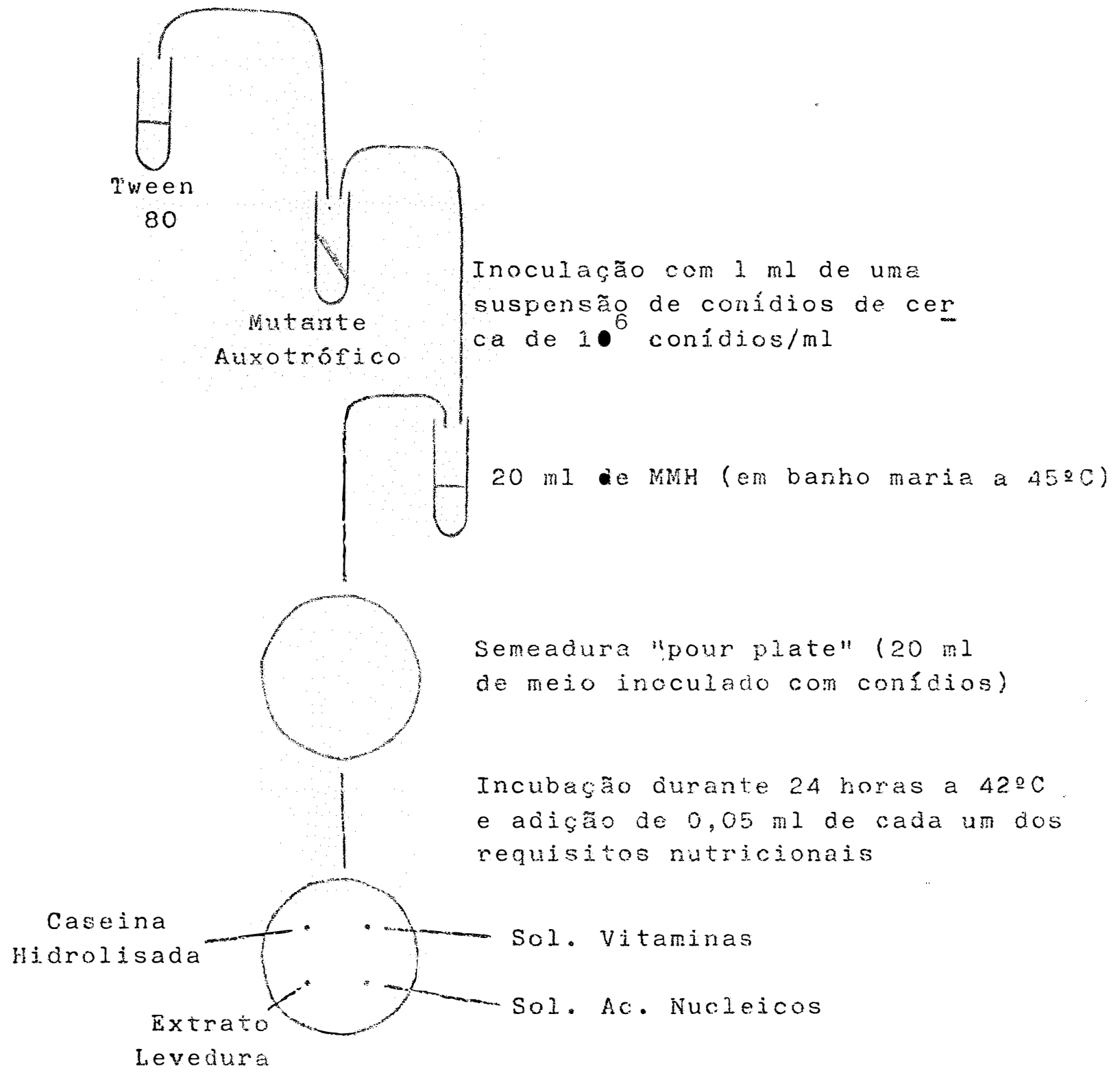

Fig. 1. Esquema do método de caracterizaçäo de mutantes auxotróficos por semeadura. 
3.7 Seleçäo de variantes para maior produção de enzimas celuloliticas.

A seleção de variantes para maior produção de enzimas celuloliticas consistiu da selegão em placa, da dosagem enzimática das variantes selecionadas e das análises esta tisticas aplicadas a esses dois estudos.

\subsubsection{Seleção em placa.}

Foj. montado um esquema de seleção, emi mejo para visualizaça de halo de degradaça de celulose (item 3.2 .9 ) de variantes para maior produça de enzimas cejuloliticas. N mesmo foram realizados 3 ciclos de seleçấo de cada un deles foi selecionada a variante de meshor indice de atividade erzi. mática em base aos resultados das análises estatisticas da se leção em placa (item 4.7.1). O Indice de atividade enzimática foi determinado pela relação entre o diêmetro do halo ... de degradação de celulose e o diâmetro de crescimento da colônia estimando-se assim a produção de enzima.

No primeiro ciclo estudaram-se 100 colônias do fungo no seu estado selvagem com 4 repetiçots. de cada uma de... las (fig.2). A variante selecionada neste ciclo foi protoplas tizada como descrito no item 3.5.1, com um tratamento enzimático de 30 minutos como estabelecido no item 4.2.4.1. Uma par te dos protoplastos foi irradiada (item 3.5.3) durante 1 minu to como estabelecido no item 4.2.2, e a outra não. Após a sua regeneração (item 3.5.2), colônias provenientes desses dois 
grupos de protoplastos foram inoculadas no meio para visualizacão de halo, iniciando o segundo ciclo de selecão. Assim fo ram ensaiadas 50 colonias de cada um dos grupos de protoplastos em comparação com 50 colônias da testemunha lesta última sempre foi a variante selecionada no ciclo anterior que näo sofria protoplastização nem irradiação). Foram ensaiadas 3 co lônias por placa (com duas repetiçōes) uma de cada um dessess 3 tratamentos: Protoplastos Irradiados (I), Protoplastos Năo Irradiacos (NI) e Testemunha (T) (fig.2). Desta mesna forna e a partir da variante selecionada no segundo ciclo foi implartado o terceiro ciclo de seleçăo. Para as variantes seleciona das nos 3 ciclos assim como o selvagem foi estudada sua ativi dade enzimática pela determinaçấo da sua atividade en papel de filtro (FPA) (item 3.7 .2$)$.

\subsubsection{Dosagem Enzimátjoa.}

3.7.2.1 Determinação de Celuiases.

o processo todo da determinagäo de celulases está esquematizado na fig.3. A primeira etapa é a produça da massa micelial, para isso prepararam-se 3 frascos erlenmeyers com $100 \mathrm{ml}$ de MMH Ifquido adicionado de $5 \mathrm{ml}$ de una soluça de glicose $20 \%$ (item 3.2.5) todo previamente esterilizado. Os mesmos foram inoculados com $1 \mathrm{ml}$ de uma suspensão de Tween 80 com $10^{5}$ conídios/ml, então foram incubados em agitador rotato rio (150 rpm) a $42 \% \mathrm{c}$ durante 72 horas.

A segurda etapa foi a colheita e lavagem da ma 
ssa micelial para retirar a glicose. Reuniu-se o conteúdo dos 3 frascos em um só e se deixou decantar o micélio, descartouse o sobrenadante e adicionaram-se aproximaàamente $250 \mathrm{~m} i$ de solução de PBS (item 3.3.19). Agitou-se o frasco e se esperou decantar o micélio para recomeçar o processo novamente. Repetiu-se esta operagão 4 ou 5 veres.

Uma vez reailzåa a lavagem, a massa miceliaj foi resusperdida em Mn (sem glicose) esperando-se decantar o micélio. Frascos de $225 \mathrm{ml}$ com $25 \mathrm{ml}$ de meio liquido para pro dução de celulases foram inoculados com l ml desse micêlio se dimentado. Incubarammse em agitador rotatório (150 rpm) a 4020 durante $12,24,36$ e 48 horas. Filtrou-se o meio; com o micelio - determirou-se o peso seco, o riltiado foi centrifugado a 4000 rpm durante $10 \mathrm{minutos}$ com - sobrenadante se tez a determinação da celulase total (item 3.7.2.2) e o açucar redutor (item $3 \cdot 7 \cdot 2 \cdot 3)$.

3.7.2.2 Deterninação da Celulase Total (FPA).

Para a escolha do meio liquido de produçăo de celulases a ser utilizado na análise da Atividade de Papel de Filtro (FPA) foi previamente feita uma dosagem de celulase to tal nas condiçôes experimentais já descritas (item 3.7.2.1). Compararam-se o meio de PETTERSON et alii (1963)(item 3.2.10), já utilizado com o Humicola sp por MACEDO (1986), e o meio $E$ desenvolvido neste trabalho (item 3.2.11).

A ceterminação da celulase total foi realizada 
pela análise da Atividade de Papel de Filtro (PPA)(MANDES et alii, 2976 ) esquematizado na fig.4. A atividade enzimática é expressa em pmoles de glicose formada/ml de filtrado/minuto. por ing de peso seco de micélio/ml de filtrado (IU/mg).

3.7.2.3 Determinaçấo do Aḉcer ledutor.

o valor do Branco da Amostía da fig. 4 equivale ao teor de acúcar redutor existente na mesma.

\subsubsection{Análises Estatísticas.}

3.7.3.1 Análises Estatistićas aplicadas na seleçäo de variantes para major produção.

O delineamento experimertal para a selecăo de variantes para maior produço foi em blocos ao acaso para os 3 ciclos de seleção.

Devido a este îngo ser altamente variável por tratar-se de um heterocario, apresentando condios nultinuclea dos (item 3.5.1) no primeiro Eiclo de selecão reram ensajadas 100 colôniaś selvagens com 4 repetições(fig.2). Cada uma dessas 100 colonias eram provenientes de um único conjidoe de cada uma delas foram tomados dojs inóculos, com 2 palitos, de duas regiões diferentes da colônia. Com cada um foran feitas duas repicagens, uma em cada placa, resultando assim 4 repeti coôes. Desta forma pode-se estabelecer um esquema de análise estatistica que permitiu estudar a variabilidade devido ao am biente, assim como a variabilidade genética entre colônias $\varepsilon$, 
pensando na heterocariose, a variabilidade genética dentro da propria colonia.

No segundo e terceiro ciclos de seleçäo, basea dos nos resultados do primeiro ciclo foram eliminadas as repe tiçôes dentro da propria placa e o número de colônias foi.re. duzido para 50. Porém, com este delineamento experimental foi possivel estudar o efeito da protoplastizaçäo e da irradiaçäo como causas do incremento na producăo de enzimas. Pelo usc da testemunha fojpossível verificar a existência ou não de ganho em produção de um ciclo de seleção para o seguinte além de fazer possivel considerar o efeito de ambiente no momento de selecionar a melhor variarite através de uma correção da média pela testemunha segundo VEncovsKY ${ }^{1}$.

$$
\begin{aligned}
& \text { 3.7.3.2. Anáaises Estatisticas aplicadas a dosagem } \\
& \text { enzimática. }
\end{aligned}
$$

0 delineamento experimental utilizado para a anälise es tatistica da dosagem enzinatica fol em biocos ao acaso com os tratamentos organizados em fatorial $4 \times 4$ e foram calculadas as regressões polinomiais para cada una das variantes selecjonadas.

As análises estatisticas deste trabalho foram executadas com base em tëcnicas de anälise de variāncia, regressão polinomial e estatistica descritiva contidas em STEEL \& TORRIE (1960).

VENCOVSKY, R. ( ESALQ/USP. PIRACICABA, SP.) Comunicação pessoal, 1987 . 


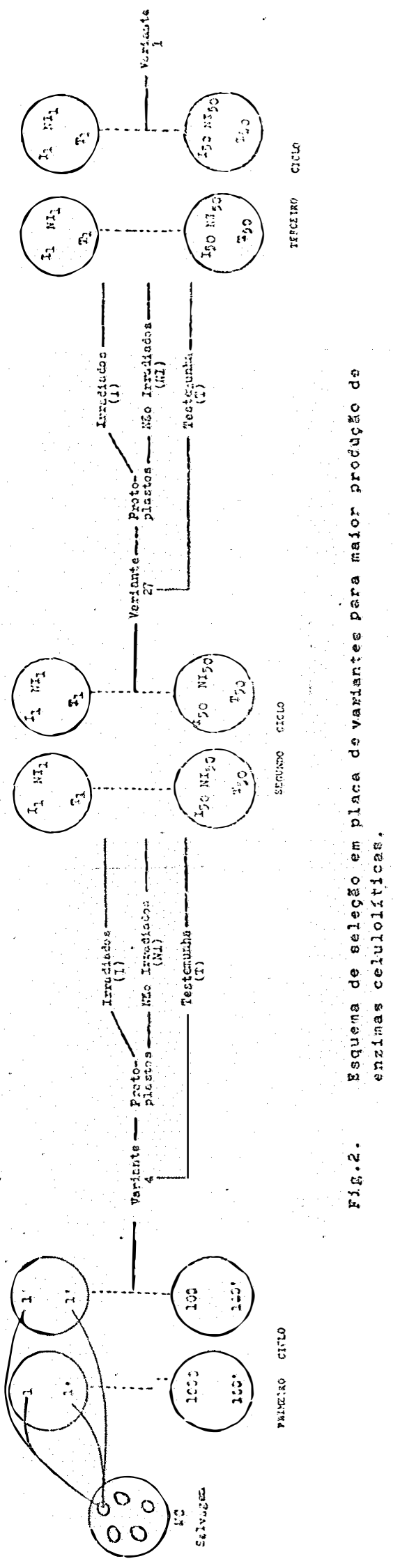




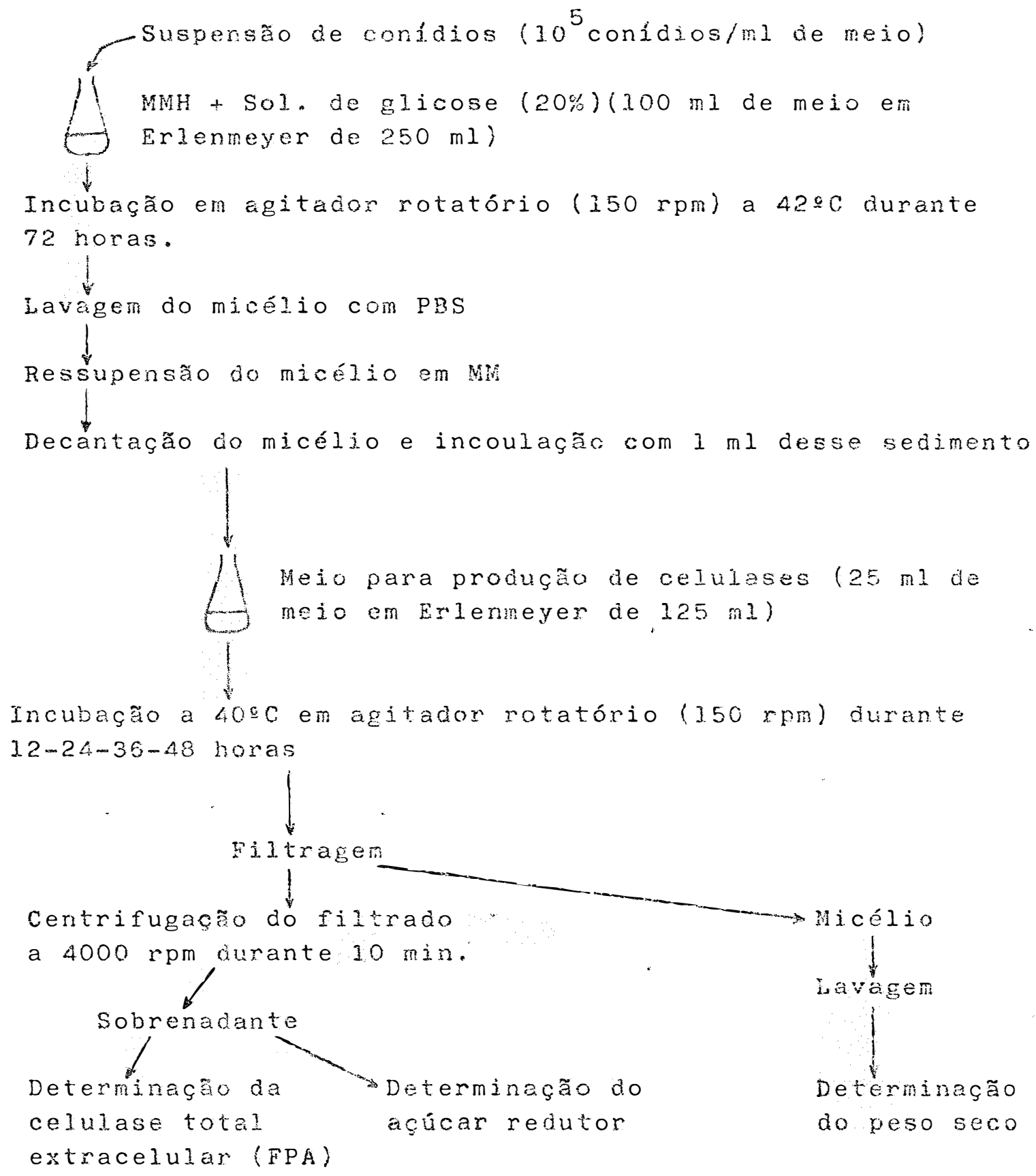

Fig. 3. Esquema do método para determinagão da celulase total, açuar redutor, peso seco do micélio. 


\section{Branco do Aparelho}

- Tampão Citrato $1,5 \mathrm{ml}$

- mirinia papel

- DNS $3 \mathrm{mi}$

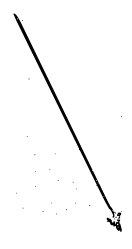

Branco de cada

Anostra

- Tampão Citrato $1 \mathrm{mI}$

- Tirinha papeI

- DNS $3 \mathrm{ml}$

- Amostra 0,5 $\mathrm{ml}$

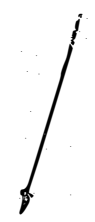

banho maria a

Incubaçầo em

$509 \mathrm{C}$ durante $60 \mathrm{~min}$.

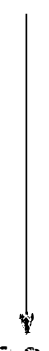

$1000 \mathrm{C}$ durante $5 \mathrm{~min}$.

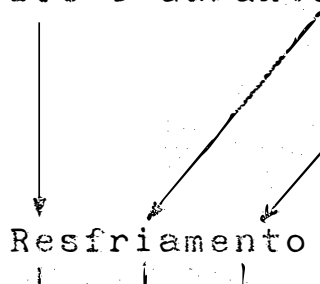

Resiriamento

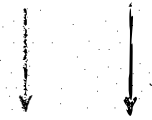

Homogeinização

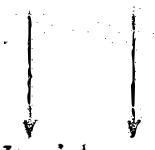

Leitura a

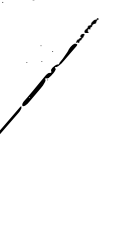

$$
\text { (2) }
$$

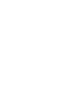

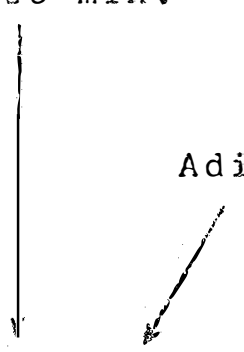

Adição de $3 \mathrm{mi}$ de DNS

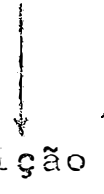

Amostra

- Tampão Citrato $1 \mathrm{ml}$

- Tirinha pape?

- Amostra 0,5 ml 
3.8 Fusão de protopiastos.

Foram ensaiacos dois métodos, a fusăo de proto plastos por tratamento com polictilenoglicol e a fusão de pro toplastos através da técnica de eletrofusão.

3.8.1 Fusão de Protoplastos por tratamento com Poljem tilenoglicol.

A fousão de protoplastos de liumicola ep foi rea lizada pela técnica de ANNE \&EBERY (1976) através do trate mento de protoplastos dos mutantes auxotróficos arg I e glu I. e do "doador morto" con polietilenóglicol.

A obtengão do micélio e dos protoplástos foi realizado como descrito no item 3.5.I. Porém, para o cresci.. mento do micéjio dos mutantes auxotróficos, ao mejo para obtença do micélio (item 3.2.5) foi adicionado a requisito num tricional $(0,25 \mathrm{ml}$ em $50 \mathrm{ml}$ de meio) para o qual o mutante tem deficiênoia.

Uma vez obtidos os protoplastos colocaram-se aliquotas das suspensões das duas linhagens a serem rundidas en um tubo de centrífuga de modo a misturar nameros aproximadamente iguais de cada uma delas. Os tubos contendo o restan te das suspensões de protoplastos das duas linhagens foram conservados para as placas controle. o tubo com a nistura de ambas linhagens foi centrifugado a 4000 rpm durante $10 \mathrm{minu-}$ tos. O sobrenadante foi desprezado e o precipitado foi ressus penso em l ml de polietilenoglicol, previamente aquecido 
30ㄷ. Então esta mistura de protoplastos foj mantida em banino -maria a $300 \mathrm{C}$ durante $10 \mathrm{minu}$ tos. Logo adicionou-se $10 \mathrm{ml}$ da solução estabilizadora $\operatorname{lMgSO}_{4} 0,5 \mathrm{M}$ em tampão fosfato $0.02 \mathrm{M}$. pH 5,6) e centrifugou-se a $4000 \mathrm{rpm}$ durante 10 minutos. Retirou-se o sobrenadante e o precipitado foi ressuspenso em 10 ml do estabilizador e centrifugado novamente a 4000 rom por 10 minutos. Esta operação foi repetida mais duas vezes. Final mente ressuspendeu-se o precipitado em 5 ml da soluça establ lizadora.

De cada uma das linhagers, fizerars-se dijuj çós em solução estabilizadora con finaìdade de semeadire das placas controle. Semearain-se placas com MC com 1.000 e 20.000 protoplastos (três placas de cada uma), con MC + esta bilizador osmótico com 1.000 e 10.000 protonlastos (tres pla cas de cada umal e no caso especíico de mutartes auxotrofi... cos semearam-se placas com MM t estabilizador osmótico (três placas sem diluição).

Da mistura de protoplastos tratada com pla somearam-se placas com MM + estabilizador osmótico adicionandom se $2 \mathrm{ml}$ e $0,1 \mathrm{ml}$ da suspensão ( 5 placas de cada uma) e en Mo + estabilizador osmótico com 1.000 e 20.000 protoplastos (5 placas de cada uma).

A porcentagen de regeneração foi calculada peIa fórmule apresentada no item 3.5 .2 enquanto a frequêricia de fusão foi calculada pela relação entre o número de colónias crescidas no $M M+$ estabilizador osmóticofnúmero de colônias crescidas no MC + estrabilizador osmótico. 
3.8.2 Fusão de Protoplastos por Eletrofusäo.

Existe pouca bibliografia desta técnica aplica da a protoplastos de micnorganismos e quando encontrada ela utilizada em actérias u ieveduras, não tendo-se conhecjmento de qualquer trabalho de eletrofusão com protoplastos de fungos filamentosos. Portanto ás soluços, neios e parântros utilizados nestes estudos para fundir protoplastos de numicola sp por eletrốusão foran adaptados de outros tipos de micrex ganismos.

Devido que a técnica de eletrorusão realiza-se só com suspensốs de protoplastos em. soluções não eletroìtjcas a pH entre 7,0 e 7,3 deviu-se modificar as condiças de manutenção dos protoplastos de Humicola sp para condições com pativeis com a eletrorusăo. Entăo, foram realizados diferentes ensaios de sobrevivancia o pegeneraça de protoplastos de Humicola sp apos tracamento con soluçós de diferentes agúcares e concentragöes a pH perto da neutraisdade. Assim, após a obtenção dos protonlastos, como descrito no item 3.5 .1 , antes da eletrofusäo, os mesmos foram lavados trôs vezes nas 0 luços de eletrofusão testadas e logo ressuspensos nas mesmas aos efeitos de roalizar a fusão. Para realizar a eletrofusâo foi utilizado um eletromanipulador celular BTX, provido-de ca mara de fusão de microlâminas. Esta, permite ecompanhar o com portamento dos protoplastos dentro do campo elétrico durante o processo de fusão por observacão no microscópio óptico, que é importante para determinar se os parâmetros em que se deve efetuar a fusão. A citada câmara foi carregada com aproximada mente $50 \mu l$ de uma suspensão de protoplastos contendo entre 
0,3 e $6 \times 10^{6}$ protoplastos/ml. As solugôes para eletrofusão ensaiadas foram Sacarose 0,3 M pH 5,6 e 7,0 (item 3.3.24) Sox bitol $0,8 \mathrm{M} e 1,2 \mathrm{MpH} 7,0$ (item $3.3 .25 \mathrm{e} \mathrm{3.3.26)} \mathrm{e} \mathrm{Sorbitol}$ $0,8 \mathrm{M} \mathrm{pH} 7,0$ adicionado de FEG $20 \%$ e 40\% (item 3.3.27). Os pa râmetros de fusăo, ensaiados no eletromanipulador celular foram: 1. Alinhamento celular: tempo de 50 a 60 Hseg. com ampli tude de 45 a $80 \mathrm{~V} ; 2$. Compressão celular: tempo de 10 a 20 yseg. com anlitude de 55 a 350 y e 3 . Fusão celular: tempo de 60 a 98 useg.com ampititude de 34 a $300 \mathrm{~V}$; aplicando 1 ou 2 pulsos com um campo alternado com frequência de l. ou 2 Mrz. 
66.

\section{RESULTADOS E DISCUSEÃO}

4.1 Técnica semiquantitativa de avaliaça da produçõo de celulases em Hunicola sp.

4.1.1 Visualizaça do nalo e colora̧̧o.

$$
\text { Segundo JORGE }{ }^{1} \text { o fostato em.concentraça de }
$$

$25 \mathrm{~mm}$ afeta a exportação da endo e exocelulases, criquanto que o extrato de malte aumenta a produção de endocelulase. issim para a. visualizaça do hralo, foi ensaiada a substituição no mejo de CHAVES (1982) do extrato de levedura por extrato de malte, da celulose microcristalina por celulose ácida, prepa rada segundo o método de TANSEY (1971) e do KH ${ }_{2}{ }_{4}$ por KCl, mantendo a concentração original do ion $K^{+} j a ́$ que segundo CHA VES (1982) este é importante para o crescimento do Humicola

JORGE, J.A. Departamento de Biologia, Faculdade de Filosofia, Ciências e Letras de Ribeirão Pretol USP. Comunicação Pessoal, 1987. 
sp pois ele agiria como mecanismo de co-transporte da glicose. De acordo com os resultados (Tabela I e 2) no meio com extrato de levedura as coionnias apresentaram maior erescimento, mas nầo produziram halo de degradação da celulose, enquanto que no mejo com extrato de malte houve produção de halo. Foi também ensaia do um método simples de coloração que permitiu vevelar melhor a presença do halo. Segundo TEATHER \& WOOD (1982) a interaça do vermelho congo com polissacarídeos ( $B-D-g l u c a n a s)$ conterdo ligaçöes $\beta(1-4)$ ou $\beta(1-3)$ däo un complexo vermelho intenso, cuja ror maçäo é evitada pela ação das B-glucanases. Entretanto, este mé todo de coloraça de TEATHER \& WOOD (1982) toma o meio de cultuia extremamente escuro dificultando a visualizaça do halo. No precesso aqui desenvozido (figura 5) a visualizagãó bem mais evidente näo serdo necessária a utilizaça do HCl I N como descrito por PEATHER \& WOOD (a98?) una vez que este tem como unica finalidace a estabilizaça dos halos de hidrósise por inibição da atividade enzimática.

segundo SHARMA et alii (1986) alguns compostos quimicos interferen com o vermelno congo 1 initando o us deste corante para a deteção de atividade celulolitica. por exemplo o detergente triton-X-100, lisozima, hidroxido de bário e cloreto de bário podem induzir a resultados falso positivos;também alguns - sais como $\mathrm{ZnCl}_{2} ; \mathrm{HgCl}_{2} ; \mathrm{Pb}\left(\mathrm{NO}_{3}\right)_{2} ; \mathrm{PbO} ; \mathrm{COCl}_{2} ; \mathrm{CuCl} \mathrm{e}$ $\mathrm{FeCl}_{3}$ e outras substancias como hidrocloreto de cistejna, áci... do ascórbico, 2-mercaptoetanol e persulfato de amônia precipitam o corante e inibem a sua ljgação ao polissacarídeo. 
4.1.2 Tamanho da Colônia.

Para se conseguir um tamanho de colonia adequa do estudou-se: 1) a concentração de citrato de sódio a ser a. dicionada ao meio de cultura para reduzir o crescinento da co lônia a um diâmetro tal que permitisse inocular e medir a ca. pacidade celulolitica de cinco colorias por placa. Segurdo os dados da tabela $l$ a concentraço mais efetiva ara o redutor de colônia foi a de $10 \mathrm{~mm}$. O citrato de sódio na concentraca de $5 \mathrm{~mm}$ ñ̃o reduziu o crescimento das colorias impeaindo assim visuajizar a presença do hajo. 2) temperatira e periodo de tempo de incubaçăo que pernitissem obtex colônias de tamé. rno adequado. Os dados da tabeja l indicam que as colónias in cubadas durante três dias desenvolveram-se muito pouco e portanto a margem de erro na mediçăo das nesmas foi muito grande. Com dez dias de incubacão as placas apresentaram ressecanento do ágar, não sendo possivel uma medição correta do diâmetro das colônias. Porém, colônias de 5 e 7 dias apresentaram tama nho razoável e ideal nas cordiçós utilizadas para visualização do hajo.

4.1.3 Presença de halo de degradaçäo e indice de ati vidade enzinática.

As colônias com três dias de incubação além de serem muito pequenas não apresentaram halo de degradaça de celulose. Com dez dias de incubação houve ressecamento do meio de cultivo, não sendo possivel uma medição correta do ha 10. As colônias incubadas por cinco e sete dias apresentaram 
halo de degradaçäo visivel, sendo que as cultivadas durante cinco dias a $429 \mathrm{C}$ apresentaram os maiores fndices de atividade enzimática (tabela 2). É importante assinalar que MANDELS. (1975) e MONTENECOURT \& EVELEIGH (1977), trabalhando com o mu tante QM 9414 e a linhagem selvagem QM 6a de Trichoderma reesei demonstraram a correlação positiva que existe entre a formaçåo de halo de degradaço de celulose em placa e a atividade erzimática dessas linhagens mostrando assjm a validade do uso de técnicas semiquantitativas para medir a atividade celuloítica em fungos.

\subsubsection{Choque Térmico.}

A aplicação de choque térnico, 50ㅇ durante 16 horas, auxilid a revelação do halo de degradaçăo da celulose. Segundo MONTENECOUPT \& EVELEIGH (1977) o choque têrinioo favorece uma hidrólise mais rápida da celuiose, permitindo a seie cão de colônias produtoras de enzimas celuloliticas termoestá veis. Entretanto a temperatura de 5000 conduz a paralizage do crescimento de Trichoderma reesei. A emergência do halo claro de hidrólise deve-se ao efeito combinado do aumento da atividade celuloljtica e de uma consequente inibição do cres-. cimento do fungo. Segundo os autores, isto poderia ser devido à liberação de celulases das hifias localizadas nos bordos das colônias por autólise resultante do tratamento térmico. Isto não parece ocorrer em T. reesei cujos isolados permarecem vía veis após o tratamento com altas temperaturas. O mesmo fenôme. no ocorre em Humicola sp de modo que o halo se manifesta pro- 
vavelmente em Iunção de uma maior atividade da enzima já difundida no meio quando em temperatura mais adequada. Entretan to, serão necessários mais estudos para esclarecer a ação do choque térmico favorecendo o aparecimento do halo.

Tabela 1. Diâmetros das colônias (medido em cm) de Humicola sp após inoculação en 4 meios à cultura por diferentes tempos e temperaturas (média de 5 repetiçôes).

\begin{tabular}{|c|c|c|c|c|c|c|c|c|}
\hline Temperaturá & \multicolumn{4}{|c|}{$289 \mathrm{C}$} & & \multicolumn{3}{|c|}{$42^{\circ} \mathrm{C}$} \\
\hline Dias Meio & 1 & 2 & 3 & 4 & 1 & 2 & 3 & 4 \\
\hline 3 & 0.75 & 0,66 & 0,63 & $0,4 \mathrm{~s}$ & 1,2 & 1,0 & 0,25 & 0,86 \\
\hline 5 & $*$ & 1,44 & 1,27 & 1,01 & $\%$ & 1,83 & * & 1,43 \\
\hline 7 & * & 1,42 & 2,89 & 1,23 & $*$ & 2,67 & * & 2,45 \\
\hline
\end{tabular}

* Não houve praticamense inibigáa do crescimento das cojonias ocorrendo junção das mesmas o que impediu a medida do seu díametro.

Meio 1: Extrato de Levedura; Citrato de Sódio $5 \mathrm{~mm}$. Meiro 2: Extrato de Levedura; Citrato de Sódio $10 \mathrm{~m}$. Meio 3: Extrato de Malte; Citrato de Sódio $5 \mathrm{~mm}$. Meio 4: Extrato de Malte; Citrato de Sódio $10 \mathrm{mM}$. 
Tabela 2. Indices de Atividade Enzimática de Hunicola sp em 4 meios de cultura em diferentes tempose temperaturas de incubação (média de 5 repeti-.. ços ).

\begin{tabular}{|c|c|c|c|c|c|c|c|c|}
\hline Temperatura & \multicolumn{4}{|c|}{$289 \mathrm{C}$} & & \multicolumn{3}{|c|}{$429 \mathrm{C}$} \\
\hline Dias & 1 & 2 & 3 & 4 & 3 & 2 & 3 & 4 \\
\hline 5 & $*$ & - & 1,27 & 1,22 & * & - & * & 1,28 \\
\hline 7 & $*$ & - & 1,05 & 1,13 & $*$ & - & \# & 1,05 \\
\hline
\end{tabular}

- Não foi detectado produção ò halo de degradaça.

* Não houve praticamerite inibiçáo do crescimento ocorren do junģ̃o das colonies o que impediu a medicão do índi ce de Atividade Enzimática.

Meio 1: Extrato de Levedura; Sitrato de Ś́dio $5 \mathrm{~mm}$. Meio 2: Extrato de Levedura; Citrato de Sódio lom . Meio 3: Extrato de Malte; Citrato de Sódio 5 m. Meio 4: Extrato de Malte; Citrato de Sódio $10 \mathrm{mM}$. 


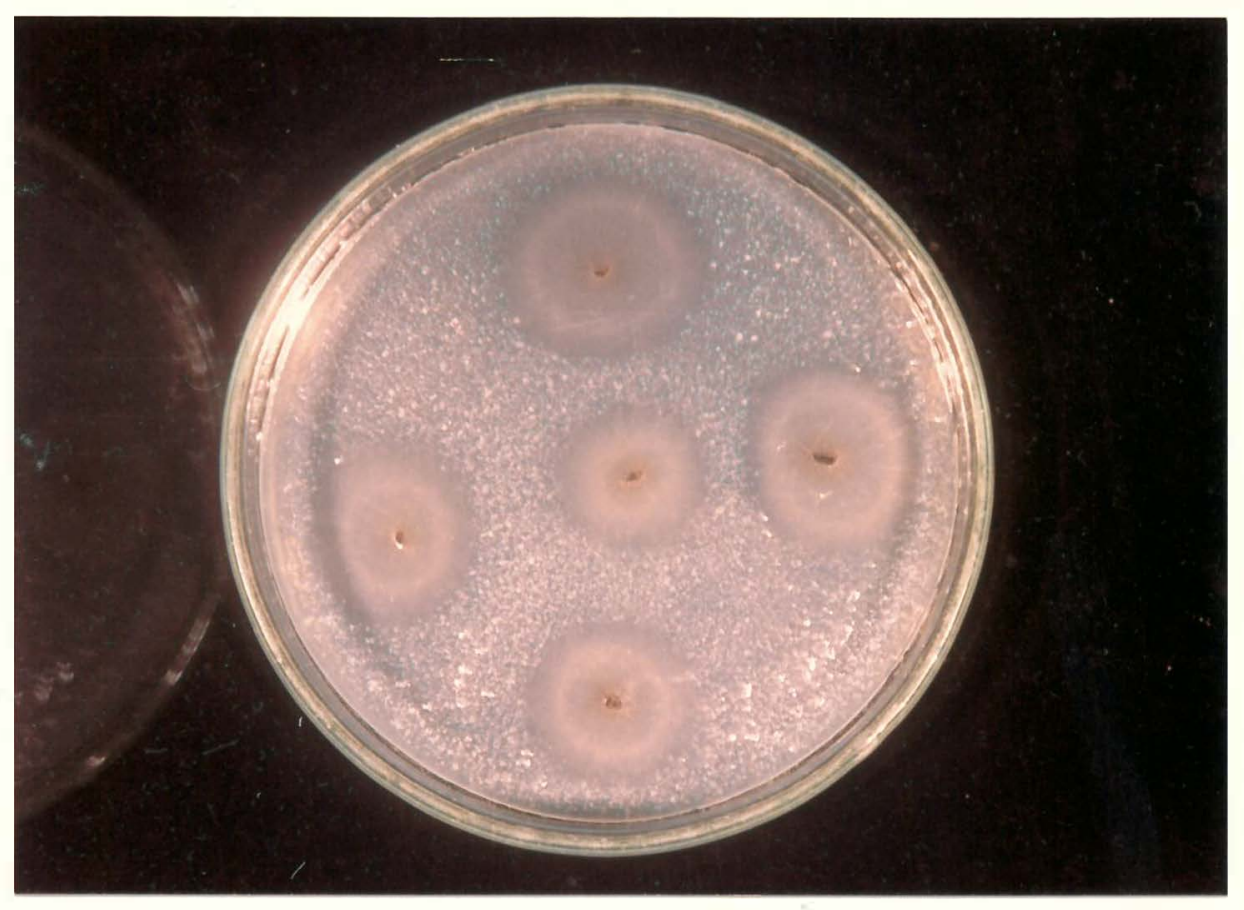

. Fig. 5 .

Placa de Petri incculada com Humicola sp, incuba da durante circo dias, após choque térmico e corada pelo método desenvolvicio no presente traba1ho. 
4.2 Protoplastos de Humicola sp.

4.2.l Regeneraça de Protoplastos.

A partir dos dados obtidos na tablela 3 fica vidente que a melior concentracăo do estabilizador osmótico pa ra a regeneração. dos protoplastos de Humicola sp é MgSO 0,25 $M$ pois a frequência de regeneração não é muito meror que em $\mathrm{MgSO}_{4} \mathrm{O}, 5 \mathrm{M}$ com o consequente menor gasto de $\mathrm{MgSO}_{4}$. A tempera tura de incubaça mais adeduada para a regeneragão foi 2800 por 24 horas e posterior transferêncì a 42 gC até completar 7 dias de incubccão. Assim protonlastoe obtjòos com 3 horas de tratamento enzimatico e regenerados em WC MgSO $0,25 \mathrm{M}_{4}$ a $280 \mathrm{C}$ durante 24 horas e logo a $429 \mathbb{C}$, tiveram una frequência de regeneração de $0,70 \%$, valor sinilar ao encontráa por MACEDO (1986) que foi de $0,67 \%$ com o mesmo tempo de fratamento enzi-... mático mas regerenamdo en $\mathrm{MC} \mathrm{MSO}_{4} 0,5$ M a $420 \mathrm{C}$ durante 7 dias. Segunda PICATAGGTO et alii (1983) a frequência de regeneraça depende, entre outros fatores, do tempo de tra tamento erzimático do micélio. Estes autores, a partir de esferoplastos de r. reesei obtjdos após 24 horas de tratamento enzimátice tiveram lima regeneraçă de menos de $1 \%$ enquanto os obtidos após b horas de tratamento regeneraram em quase $100 \%$. Porém, TOXAMA et alii (2983) também con protoplastos de reesei obtidos a partir de conídios imaturos após o mesmo tem po de tratamento enzimático. (6 horas) obtiveram uma frequência de regeneração de apenas 1\%. PEBERDY \& GIBSON, (1971) regeneraram com frequência de $50 \%$ protoplastos de A. nidulans 
obtidos após 2 horas de tratamento enzimático. As condiços osmóticas são outro dos fatores importantes, assim AHN \& PACR (1985) aumentaram a frequência de re eneraça em S. cerevisiąe de $17 \%$ para $35 \%$ pela pré-adaptação, das células a serem proto plastizadas, ás mesmas condigões hipertônicas utilizadas na regeneraçăo dos protoplastos. Pelos dados aqui apresentados obsenva-se que a frequência de regenenaçầ de tiumicola sp é considerálulmerte baixa mas resta a possibilidade, de através de uma pre-adaptação osmótica aumentar a mesme.

Tabela 3. Efeito da temperatura e concentraça do estabilizador osmótico na regeneraça de protoplastos de Humicoia sp.

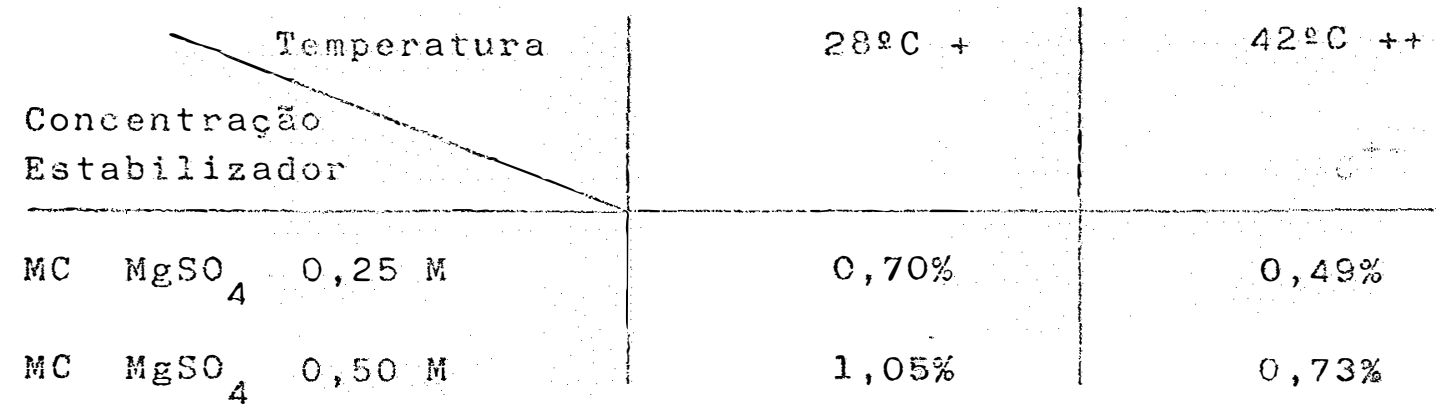

7. Incubado a 28 C durante 24 horas e logo transferido a $420 \mathrm{C}$ atté completar 7 dias de iricubação.

+ Incubado a $42 \circ \mathrm{C}$ durante 7 dias. 
4.2.2 Curva de Sobrevivência de Protoplastos á luz Ultravioleta (UV).

A curva de sobrevivencia de protoplastos de Humicola sp á luz UV roi estudada como descrito no item 3.5. 3. De acordo com os dados de sobrevivênia, apresentados na tabela 4 e 1 ig.6, foj estabelecido como metodologia de trabaIho para o futuro desta pesquisa, aos efeitos da obtenço de mutantes e ou variantes genéticas, irradiar os protoplastos du rante I minuto, dose de Uv que deve estar cerca do 5\% de sobrevivência desejado (AZEVEDO \& COSTA, 1973).

Tabela 4. Porcentagen de sobrovivencia é luz ultravioleta de protoplastos de Humicola sp.

\begin{tabular}{c|c|c}
$\begin{array}{c}\text { Tempo de Irradiacão } \\
(\text { segundos }\end{array}$ & $\begin{array}{c}\text { Dose de UV } \\
\text { emoules } / \mathrm{m}^{2}\end{array}$ & $\%$ de Sobrevivência \\
\hline 0 & 0 & 100 \\
10 & 50 & 25 \\
20 & 100 & 18,75 \\
40 & 200 & 9,75 \\
80 & 400 & 2,50
\end{tabular}




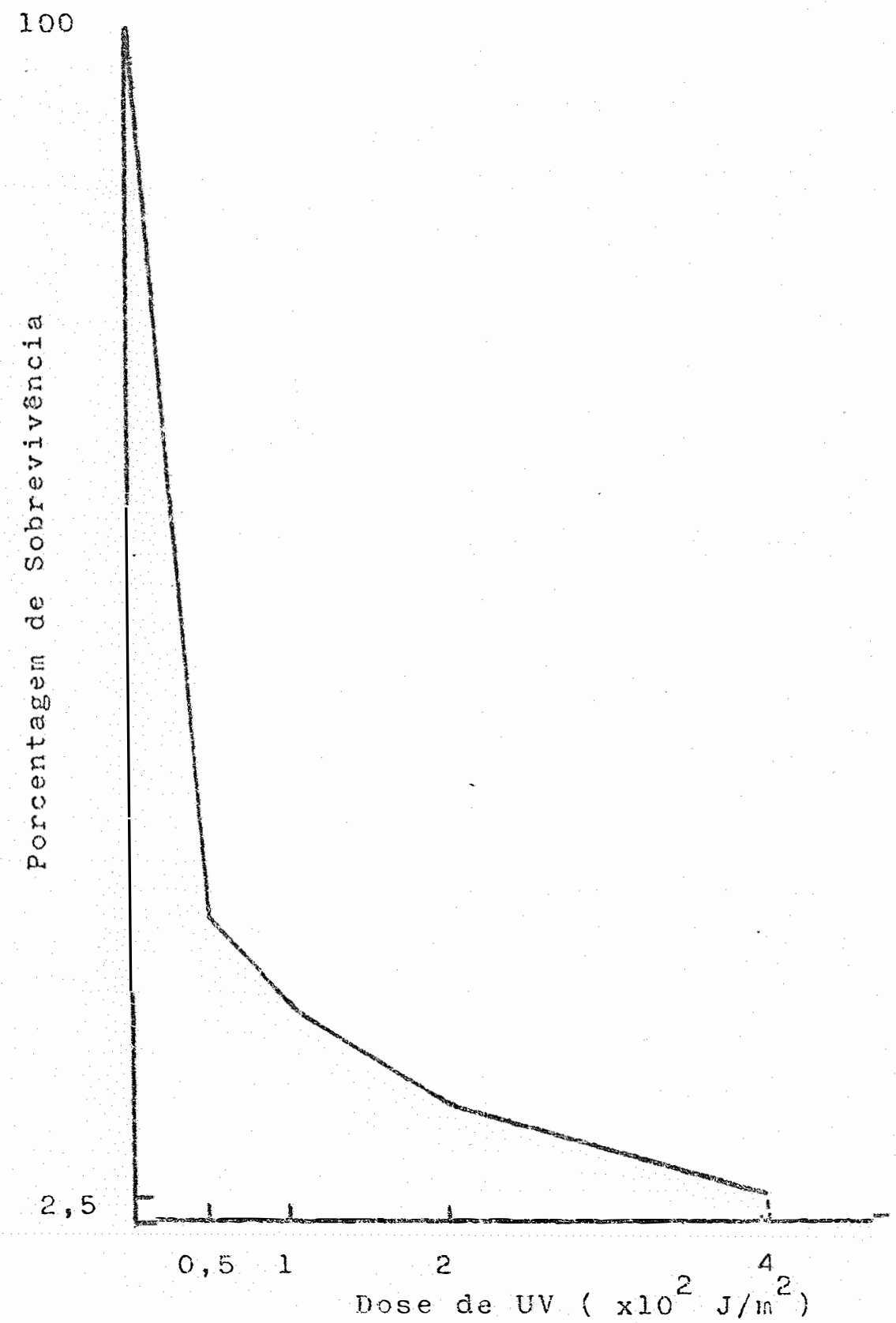

Fig. 6. Curva de sobrevivência á luz ultravioleta cie protoplastos de Humicola sp. 
4.2.3. Técnica do Doador Morto.

Para a realização de cruzamentos genéticos por fusão de protoplastos, dentro da nesma linhagem, é indispensá. vel o uso de marcas de resistência, auxotrofia, ou outras, que posibilitem o reconhecimento dos produtos de cusão. Porém, to dos esses mutantes são obtidos através do uso de algum agente mutagênico, cuja ação nunca é dìrecionada, podenco então carre gar junto com a marca procurada alguna outra alteragão genética não desejável. Para evitar esse inconveniente ó possival uti lizar o chamado "doador morto". Estra técnica é então de gran... de utilidade no melhoramento genetico de espécies de importan cia industrial uma vea que a técnica do doador morto elimina a necessidade de um trabainoso programa de mutagenese (PEBER... DY, 1985) e evita os riscos das mutaçôs aleatôrjas. Este "joa dor morto" pode ser obtido de diversas formas, mas para näo in troduzir alterações genéticas indesejáveis é interessante obie.. los através do uso de calor. Para produzir o menor dano possi vel aos protoplastos, procura-se aplicar a temperatura mais baixa e o menor periodo de tempo possiveis, que eliminem to $100 \%$ dos protoplastos.

Segundo MATSUSHIMA \& BALTZ (1986) os protoplas tos inativados pelo calor não säo capazes de regenerar mas po dem doar o seu material genético à célula receptora durante o processo de fusão.

Algumas fusões com doadores inativados pelo ca lor já tem sido realizadas com sucesso, entre elas a de FoDor. et alii (1978) em Bacillus e OCHI (1382) e BALTZ \& MATSUSHIMA 
(1983) em Streptomyces. FODOR et alii (1978) já demonstraram em bactérias Bacillus megaterium o bom desenvolvimento desta técnica, obtendo recombinantes quando usado lim parental "doa dor morto", inativado por calor a $500 \mathrm{C}$ durante $120 \mathrm{~min}$, e outro parental viável; porém não obtiveram recombinantes gag do cruzados dois parentais inativados pelo calor. En Streptomyces, oChI (1982) utilizou 600C durante 5 minutos. enquanto que BALTZ \& MATSUSHIMA (1983) usaram 50 oc por $150 \mathrm{mi}$ nutos. O procedinento de OCHI (1982) resultou em uma obtengáo de recombinantes mais pobre que a de BALTZ \& MATSUSHImA (1983). Essa diminuiçāo ra formąão de recombinantes após o tratamento a $509 \mathrm{C}$ pode ser devido ao rompimento ou desorganização dá men brana citoplasmética (BALTZ \& MATSUSHIMA, 3953). A temperatura a qual se inativam os protoplastos é critica. A mesma deve. ser o suficientemente elta como para inviabilizar a linhagem. mas deve ter pouco efeito sobre a integridade da membrana cito plasmática e o genoma. Una temperatura de inativação muito alta pode ser deletérja para os protoplastos e causar o decrésci mo na recuperaç㐅㐅̃o de recombinantes (BALTZ \& MATSUSHIMA, 1983).

Na literatura existe poucá informação a respejto desta ténica. De acordo com os resultados apresentados na Tabela 5 concluiu-se que o tratanento térmico mais adequado era $62 \mathrm{C}$ durante $10 \mathrm{minutos}$. Entretanto os dados de BALTZ \& MATSUSHIMA (1983) sugerem a realização de experimentos utijizan do um tratamento térmice mais longomas a temperaturamais bajxa. 
Tabela 5. Número de protoplastos regenerados para cada tratamento (média de 3 placas).

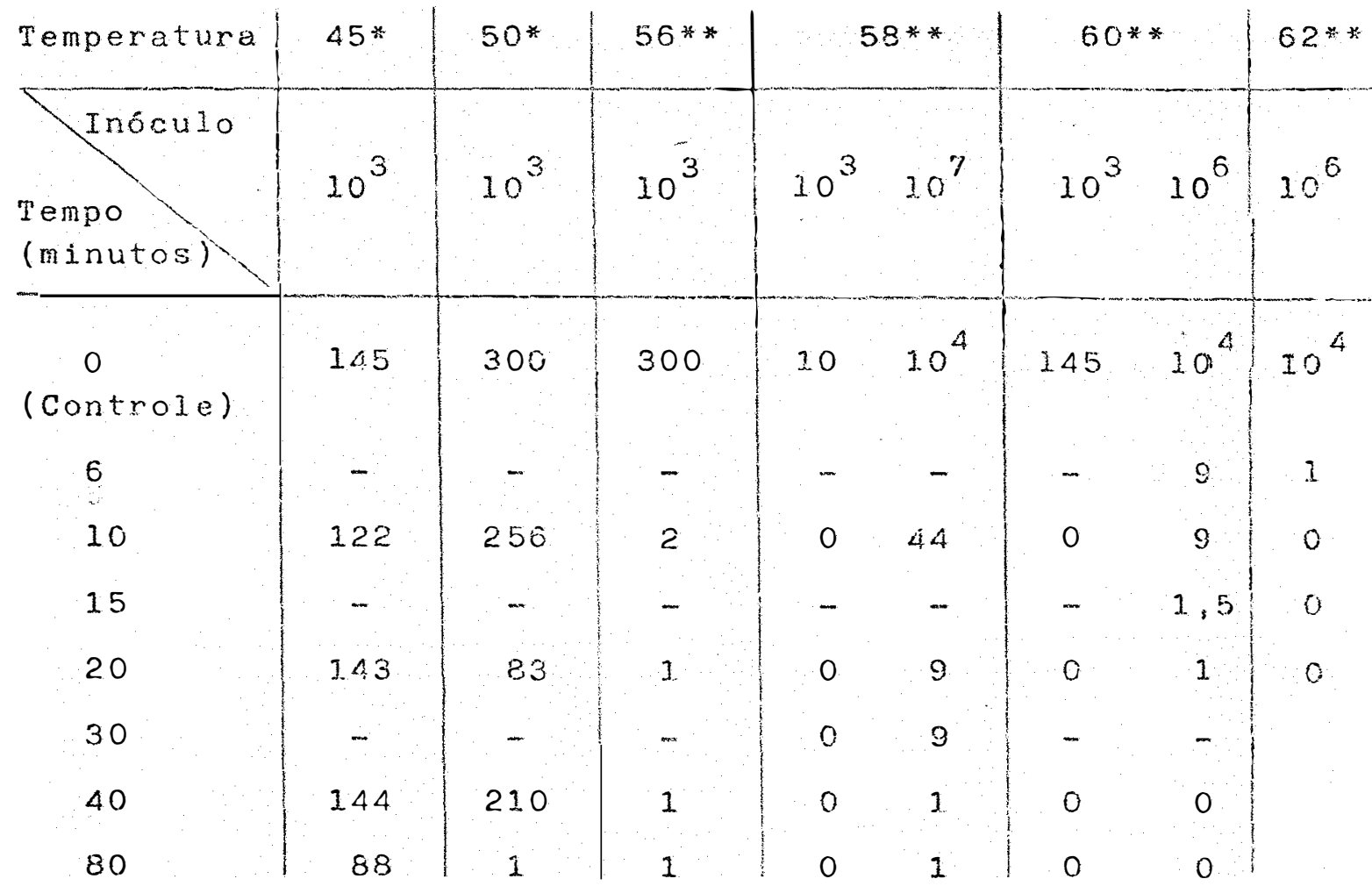

(-) Tratamentos não inoculados

(*) No de protoplastos regenerados em 2 dias de incubação. (*) No de protoplastos regenerados em 6 dias de incubação. 
4.2.4 Liberação de protoplastos a partir do mácílo. 4.2.4.I Tempo de Tratamento Enzinâtico.

A ocorrência de protoplastos vacuolados (fig.

71 e $7 \mathrm{n})$ e a presença de micélío bem fragmentado con abundan tes protoplastos (fig. 7 e; $7 \mathrm{f}$ e $7 \mathrm{~g}$ ) mesmo no injoio do tratamento enzimatico ( 30 minutos), foi cbservad em bumicola sp coincidentemente com o assinazado por DE VRIES \& VESSELS (1972) pelo liso de $\mathrm{MgSO}_{4} 0,6 \mathrm{M}$ como estabilizador usmótico em fungos filanentosos. Ainda para este mesmo tempo de tratamento pode-se observar a presenca de esferoplastos (fig.7 h). Após 1. 2 ou 3 horas de tratamento enzinático, coservaram-se suspensöes de protoplastos sem rasiduo ou fragnentos de mícélio, sendo na sua grande majoria células que apresentam vácholos de grande volume ( $f^{\prime} \dot{g} .7 \mathrm{i}$ até $\left.7 \mathrm{r}\right)$.

PEBERDY \& GIBSON $(2971)$ encontraram: em Aspergillus nidulans, protoplastos após 45 a 60 minutos de tratamento enzimático, enquanto FICAIAGGIO et alii (1983) em Trichoderma reeget so apss 90 minutos. Porem, no proeate tra balho apos 30 minutos, obteve-se $3.5 \times 10^{6}$ protoplastos/ mi de caldo de digestâo. Com tempos de tratanento mais lorgos, o numero de protoplastos obtidos foi aumentado até chegar a um méximo de $1,9 \times 10^{7} / \mathrm{ml}$, com 3 horas de tratamento (rabela 7 e fig.10). A regeneração, ao contrário da obtenção de protoplastos, teve o seu máximo $(1,258 \%)$ com protoplastos de 30 mi nutos (tabeia 7 e figlli), dininuindo com periodos de tratamento enzimático mais longos. Estes resultados coincidem com - encontrado por PICATAGGIo et alii (l983) onde a fréguência 
de regeneraça dos esferoplastos no meio completo é inversamente proporcional ao tempo de tratamento enzimático. NECAS (1971) acredisa que os resquicios de parede celular possuen una partiojposo aportante na reconstituiça da nova paredo, e portanto na regeneraço desses eateroplastos. As afirmacoe desteb atores conínam os resultados encontrados no presente trabalho e portanto pensa-se que a presença de esferoplas... tos ( $f i g .7$ h) aeve ser o motivo pelo qual a frequência de regeneração é major em protoplastos obtidos con 30 minutos da tratamento enzimético do que en tratamentos mais longos.

A contagem do número de núcleos nos protoplas... tos obtidos en diversos tempos (tabela 6) demorstrou que a maior porcentagem de protoplastos uninucleados é encontrada aos 30 minutos $(75,5 \%)$ e com o aumento do teinpo de tratameato enzimático esta porcentagem diminui.

A análise de variância do dianetro dos proto plastos obtidos após 30 minutos e 3 horas de tratamento enzi.. mático apresentou um coeficiente de variação de $16,64 \%$ e demonstrou que o tamanho dos protoplastos obtidos após 3 horas $(3,341 \mu m)$ é maior que o dos protoplastos obtidos após $30 \mathrm{mi}$ nutos de tratamento enzimático $(3,095 \mu \mathrm{m})$, diferenga esta que é significativa a nävel de $1 \%$

Esta diferença em tamanho provávelmente se deve ao fato de que os protoplastos multinucleados são maiores que os uninucleados, tal como acontece com os conidios diplói des e haplóides de A. nidulans e A. niger ( PON $1953)$. 
4.2.4.2 Emergência dos Protoplastos.

Em Aspergillus nidulans (PEBERDY \& GIBSON,1971) e Trichoderma reesei (PICATAGGIO et alii, 1983) após curtos periodos de tratamento enzimático que variam de 45 a 90 minutos, os esferoplastos são liberados exclusivamente de pontas de hifas, sendo pequenos e desprovidos de vacúolos. No presen te trabalho, já com 30 minutos de tratamerto enzimático foram observados esferoplastos que emergem atrápes de orificios for mados na parede em diferentes regiones das hifas e rão exclusi. vamente nas pontas das mesmas. ( $f \mathrm{ig} .8$ a; 8 b e 8 c).

4.2.4.3 Divisão Celular nos Protoplastos.

Nos protoplastos de lumicola spencontiaram-se núcleos em divisão, tanto no comeco do tratanento enzimático ( 30 minutos, $\mathrm{ig}$. 9 a), como om tempos majs $10 n g o s$ ( I hora, fig. 9 b e 3 horas, fig. $9^{\circ}$ c) o que está dé acordo com os dados de NECAS (1971) que verificou que mesmo interserindo com a sequência normal de eventos do ciclo celular o estado de protoplasto não impede que a massa celular aumente e haja divisões nucleares. Porém, a citocinese fica paralisada e os protoplastos não se dividirăo até que não tenham a sua parede celular reconstituida. 
Tabela 6. Número de núcleos em protoplastos de Humicola sp, obtidos após diferentes tempos de tratamen to enzimático.

\begin{tabular}{|c|c|c|c|c|c|c|}
\hline $\begin{array}{l}\text { Tempo décleos } \\
\text { Tratamento } \\
\text { (minutos) }\end{array}$ & 1 & 2 & 3 & 4 & Total & $\begin{array}{c}\% \text { Uni- } \\
\text { nucleados }\end{array}$ \\
\hline 30 & 302 & 87 & 8 & 3 & 400 & 75,5 \\
\hline 60 & 318 & 125 & 7 & 2 & 452 & 70,35 \\
\hline 320 & 327 & 202 & 21 & 1 & 551 & 59,34 \\
\hline 180 & 260 & 172 & 19 & 3 & 454 & 57,26 \\
\hline
\end{tabular}

Tabela 7. Número ae protoplastos/ml obtidos em diferentes tempos de tratamento enzimático; porcentagera de regenerạ̧a e seu diametro.

\begin{tabular}{|c|c|c|c|}
\hline $\begin{array}{c}\text { Tempo de } \\
\text { Tratamento } \\
\text { Enzimático(mi- } \\
\text { nutos })\end{array}$ & $\begin{array}{c}\text { Námero } \\
\text { de } \\
\text { Protoplastos } / m l\end{array}$ & Regeneraçào & $\begin{array}{l}\text { Diametro dos } \\
\text { Protoplastos } \\
\text { ( } \mu \mathrm{m})\end{array}$ \\
\hline 30 & $3,6 \times 10^{6}$ & 1,258 & 3.095 \\
\hline 60 & $5,6 \times 10^{6}$ & 1,115 & $\ldots$ \\
\hline 90 & $1,0 \times 10^{7}$ & 0,958 & - \\
\hline 120 & 1., $4 \times 10^{7}$ & 0,858 & - \\
\hline 150 & $1,6 \times 10^{7}$ & 0,922 & - \\
\hline 180 & $1,9 \times 10^{7}$ & 0,005 & 3,431 \\
\hline
\end{tabular}

(-) Não medido 


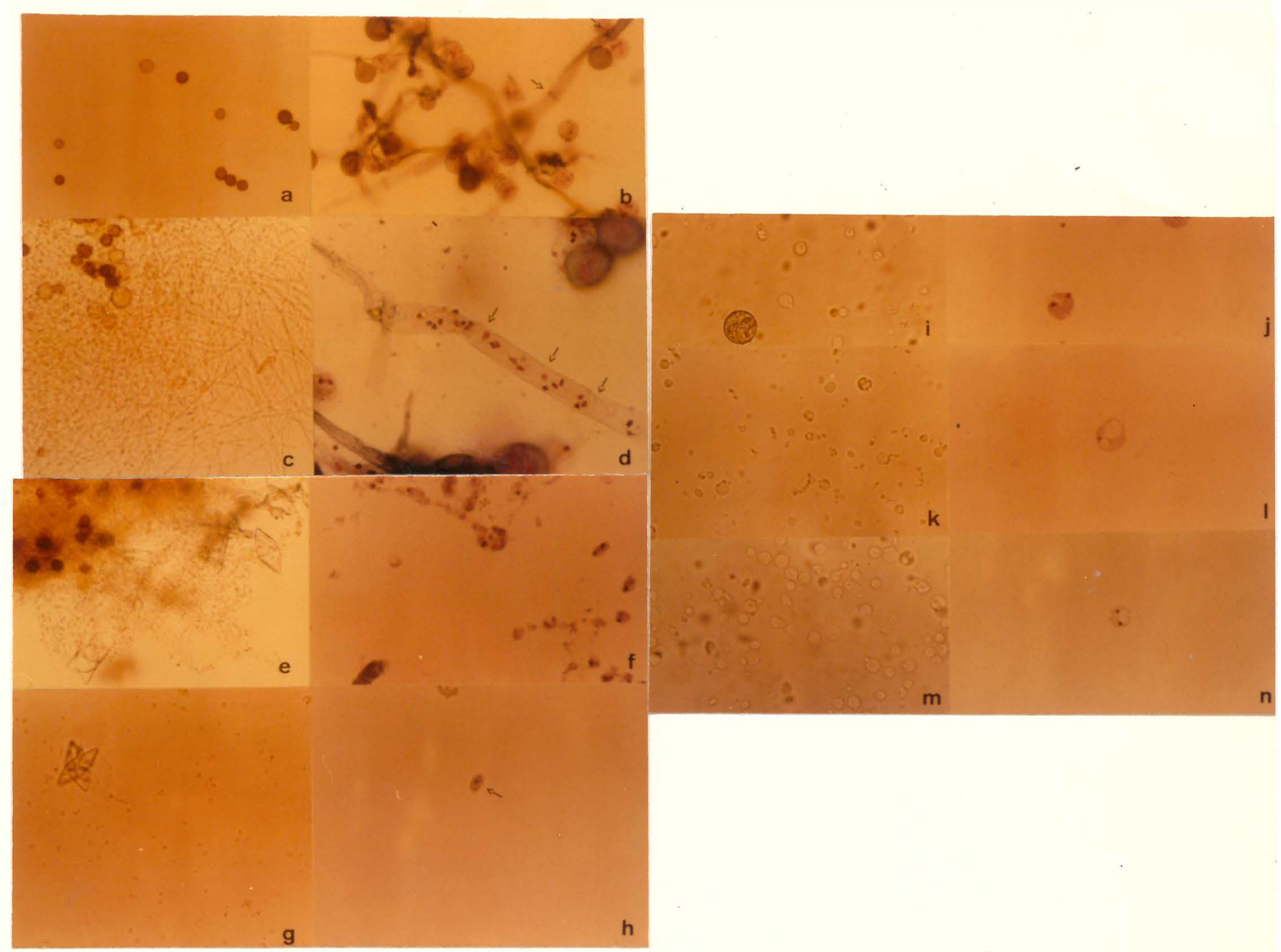

Fig. 7. Sequência da obtenção de protoplastos de îumicola sp com diferentes tempos de tratamento enzjmático do micélío. (a, b, c, c, di micélio, conidios multi... nucleados e hilas septadas multinucieadas sem tra tamento enzimático. e, f, gs h: micélio e protoplastos obtidos com $30 \mathrm{mj}$. de tratamerto enzjmático. I-_j: protoplastos de 60 min. de tratamento enzínáticc. k. I: protoplastos de 120 min. de tra tanento. m, n: protoplastos de 180 min. de trata mento enzimático). 


$$
\text { 目 }
$$




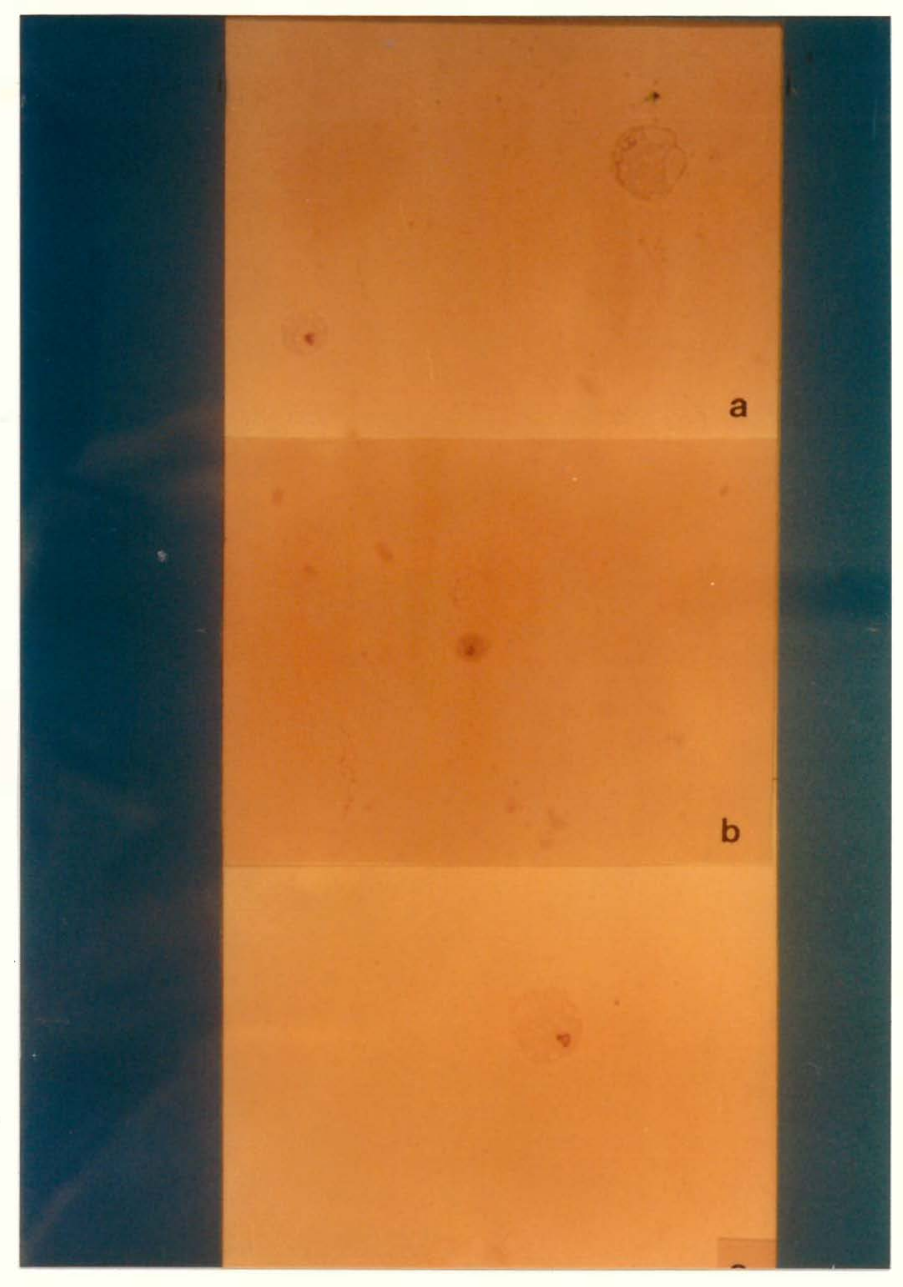

Fig. 9. Frotoplastos em divisão nuclear, podendo-se observar cromossomos. 


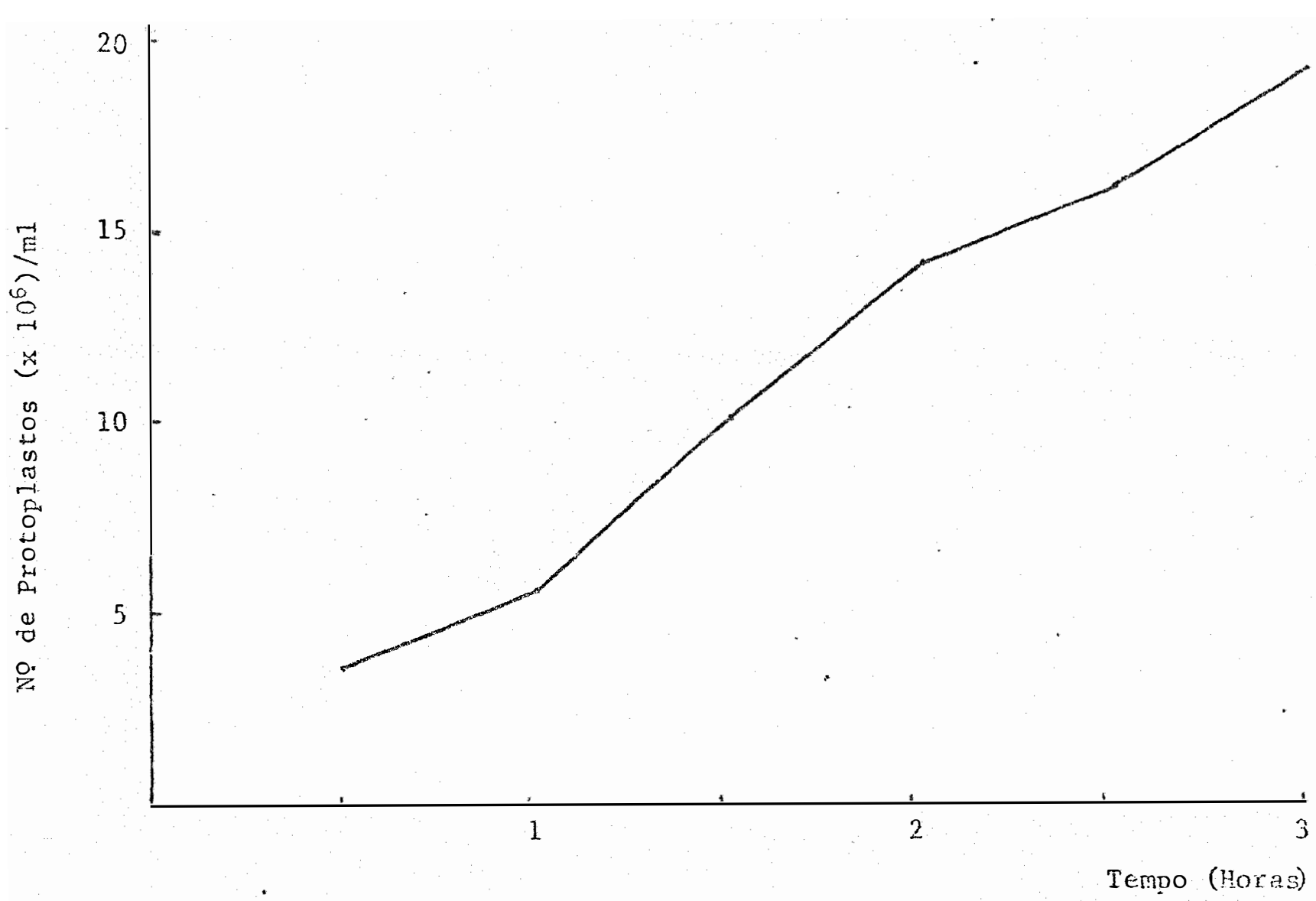

Iig. 10. Efeito do tempo de tratamento enzimático na obtenção de protoplastos.

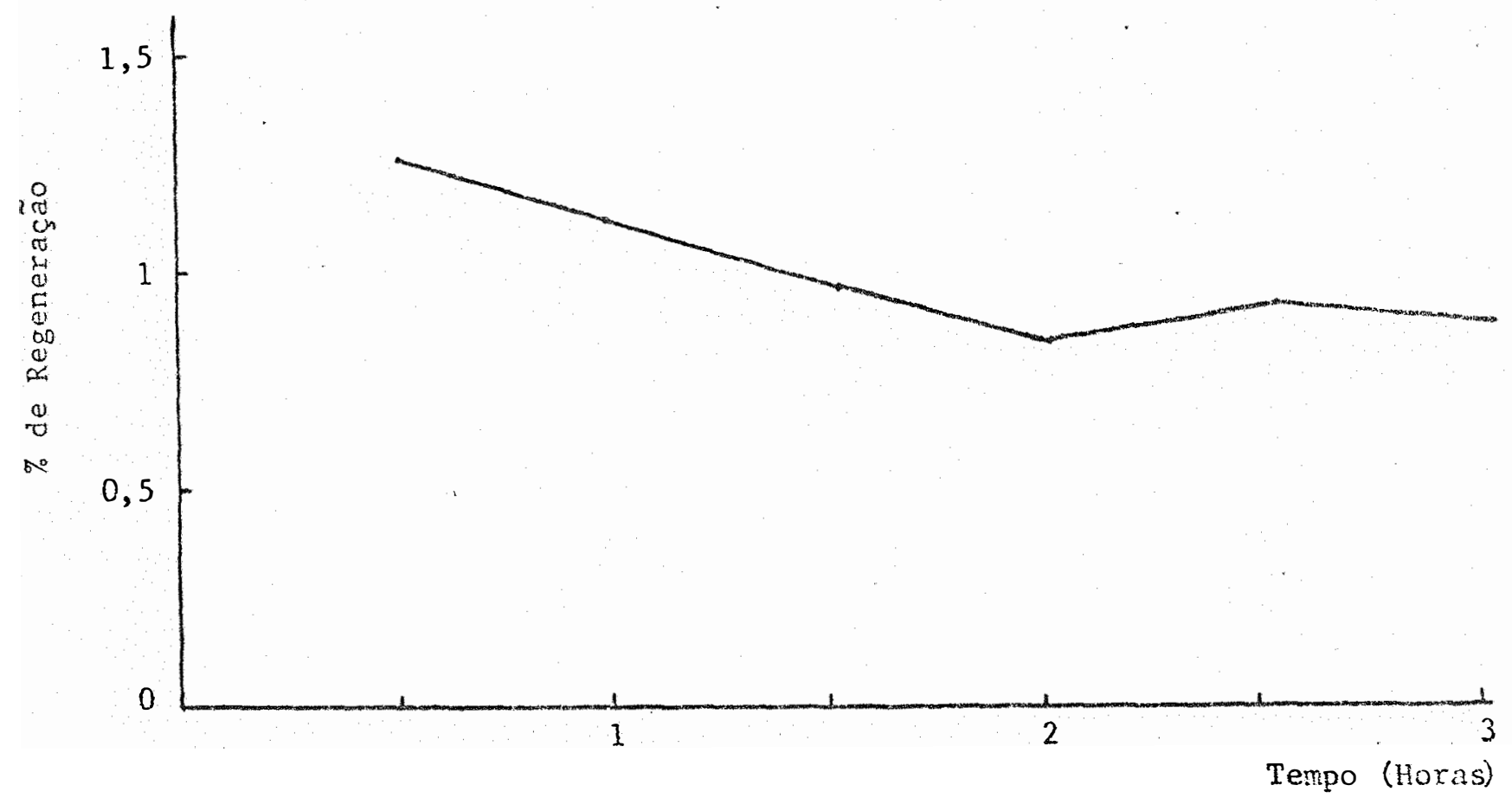

Fig. 11. Efeito do tempo de tratamento enzimático na regeneração de pro toplastos. 


\subsection{Marcas Genéticas.}

4.3.1 Mutantes Morfologicos.

O seu isolamento e caracterizacão foram reali$z$ ados de acordo com o item $3.6,1.1$.

Foram analisadas 790 colônias isolando-se 8 co I8nias de morfologia alterada em relaçà à linhagem selvagem, - que corresponde a $1,01 \%$ de mutantes. Os mukantes foram de tipo coloração alterada $(\hat{x} \dot{i g}, 12)$.

GUPTA et alij (193l) por tratamento com nitrosoguanjidina de um rungo do gênero phomes cotiveram um mutante morfológico denominado $\mathrm{km} 7$ que incrementou a producão de B-glicosidase en 8 vezer e de carboximetilcelulase em 3 vezes. Mesmo existindo na literatura outros exemplos de mutantes mor. fológicos ligados a aumento de produção (ALXKAANAN, I962) Gs te tipo de mutante tem a sua importanoia própria como marca genêtica para o melhoramento de microrganismos através de tés-nicas de recombinação genêtica.

\subsubsection{Mutantes Desreprimidos.}

Eles foram isolados segundo a técnica descrita no item 3.6.3.2. Foram analisadas 790 colônias obtendo-se 4 mutantes desreprimidos, o que corresponde a $0,5 \%$ de mutantes.

Os mutantes desceprimidos apresentam atividade celulolitica mesmo na presença do repressor catabólico (glico cose ou glicerol). Estes mutantes säo selecionados para obter Iinhagens hiperprodutoras de enzimas (DEMAN, 1972), pois a perda do mecanismo de controle pode resultar em uma hiperpro- 
duçäo destas enzimas.

As enzimas celuloliticas são catabolionmente reprimidas, mas a obtenção de mutantes capazes de sintetizar celulases ein condiçōes de alta repressão catabólica (nutantes desreprimidos) é um meio bastante seguro para aumentar o ren-.. dimento da produça de celulases. MONTENECOURT \& RVELEIGI

(1977a e 1977o) isolaram o mutante RUT NG-14 produtor de celu lases em placa dé ágar com 5\% de glicerol, mas em meio líquído o mesmo mostrou somente desrepressåo parcial do complexo ceiu lase. Apesar de que os 4 mutantes aqui isolados apresentaram uma zona de degradaço de celulose bem niticia mesmo em presen ca de glicose $3 \%$ e en um periodo de incubação menor (3 dias) ao comumente vtilizado para medir a atividade celulolitica em placa do selvagen ( 5 dias), sua atividade hipercelulolitica deve ser confirmada en meio lígujdo.

NISIZAWA \& SUZUKI (1972) E MONTENECOUE? \& EVELEIGH (197\%a) encontraram que o glicerol é un repressor efeti vo e foi preferido para ser utilizado no lugar da glicose pois esta poderia interferir nas análises enzimáticas do furgo e necessitar de uma filtração em gel do caldo de cultivo para liminar a interferência da glicose.

4.3.3 Mutantes Resistentes.

4.3.3.1 Resistência a Benlate.

O estudo da resistência do selvagem ao benlate foi efetuado de acordo com o item 3.6.1.3.1. Segundo os resul 
tados obtidos (tabelas 8 e 9 , Iig.13) verifica-se que a linha gem selvagem é resistente $a 0,36 \mu g$ de Benlate/ml de MC. SANTOS \& AZEVEDO (1982) encontraram que o Metarhizium resiste até 4,O $\mu \mathrm{g}$ de Benlate/mI de MC. Isto demonstra que Humicola sp é fortemente inibido por esse rungicida. De acordo com esses resultados decidiu-se utilizar uma concentração de $0,4 \mu g / m I$ para se obter mutantes resistentes a este fungicida. Da suspensão de coníaios, da linhagem selvagen, semeada (106 conidios por placal isolaram-se 6 colônias resistentes a $0,4 \mu g$ de Benlate/ml de MC, sendo a frequêricia de nutação espontânea aproximadamente de 1,20 mutantes em $10^{6}$ conídios. Esta frequência é intermedia á ercontrada por AZEvEDO et alij(1977) com cloroneb em A. nidulans, un mutante em $10^{8}$ conjaios, e a enoontrada por SANTOS Metainiziur que foj de 2,35 mutantes en $10^{6}$ conídios.

o teste para aumento cì resistencia, a partix de 2 colônias ( $A$ e $B$ ) resistentes a $0,4 \mu g i m d$, realizou-se co mo descrito no item 3.6.1.3.1. Os resultados (tabela 10) mos... tram que em $0,5 \mu \mathrm{g} / \mathrm{ml}$ germinaram tantos conidios que cresceram en toda a placa, indicando que essas duas colónias tamben săo resistentes a esta concentração de fungiciàa, já em 1,0 e 1,2 $\mu g / m l$ não houve crescimento. Porém na concentrágão de $0,7 \mu g$ de Benlate/ml de MC cresceram 9 e 6 colônias, estas poderiam ser mutantes naturais as resistentes a $0,4-0,5 \mu \mathrm{g} / \mathrm{ml}$ para um segundo gene de resistência. Se fosse um caracter monogênico os mutantes também apresentariam resistência para concentrações maiores, por isso este ganho de resistência aos poucos faz pen 
sar que a resistência ao Benlate se trate de um caracter poli gênico e que na resistência a $0,7 \mu \mathrm{g} / \mathrm{ml}$ há un segundo gene en volvido. Estes resultados são similares aos encontrados por SANTOS \& AZEVEDO (1982) que isolaram 5 mutantes, 3 deles apre sentaram crescimento em até $1024 \mu g$ de Benlate/ml. de MC e os outros dois só até $1.28 \mu \mathrm{g} / \mathrm{ml}$. Os autores concluiram que ou di. ferentes sitios de um nesmo gene podem ser modificados, dando diferentes níveis de resistêncì, ou entẽo, dois genes pode.. riam estar envoividos aeteiminando resistência alta ou baixa. Com a finalidace de se obter uma marca genetica para a sua utilizaça nos cruzementos e preferivel o empre go do mutante resistente a $0.5 \mu g / m i$ em lugar do resistente a $0,7 \mu g / m I$ pois este útimo precisaria sofrer una permuta dum pla para transferir a sua resistênoia. porém há necessidade de confirmęão posterior o que acarreta un major conhecimento da genética de Humicola ; a obtençăo de marcas em todos os cromossomos, como se verifica em Aspergillus nidulars, permitirá cruzamentos entre os mutantes resistentes a 0,5 e 0,7 $\mu g / m]$ e assim definir.se com certeza se se trata de um ou dois genes que estão envolvidos nessa resistência.

\subsubsection{Resistência a 2-Deoxiglicose.}

0 estudo dá resistência da linhagen selvagefii a 2-Deoxiglicose foi realizado de acordo com o item 3.6.3.3.2.

A 2-Deoxiglicose (2DG) é um antimetabólito añ tagónico da glicose e tóxico para o T.reesei solvagen, sendo que o crescimento na sua presenģa resulta na morte do mesmo. A 
resistência a este antimetabólito pode slirgir por varios mecanismos, incluindo aquele de resistência à repressão catabó-lica. Esta metodologia permitiu a obtença de alguns nutantes por exemplo O RUT-C30 hiperprodutor e resistente a repressão catabóljca (MONTENECOURT \& EVELEIGH, 1978; MONEENECOURT et alii, 1979); a partir do QM 9414 dois mutantes desreprimidos e hiperprodutores enn relacão á $\beta$-glicosidase (Costa \& VAN U DEN, 1980); o mutante DI-6 hiperprodutor e desreprimido mesino a temperaturas altas (GHOSi et alii, 1.882); mutante desreprimido e superprodutor de B-gícosidase de Fusarium graminearum (LOUREIRO DIAS, 1982).

- organismo resistente a repressão catabólica, quando cultivado em meio com 2DG/celulose, hicrolisa a celulo se para produzin glicose evitando o uso do antimetabolito. Ao contrário, Ijnagens selvagens somente poden utilizar a $20 G$ tóxica e não sobrevivem (MOTENECOURi et alij, 1979), porém is to parece náo acontecer com o Humicola sp já que o selvagem cresceu normalmente em meio com 2DG/celulose e inclusive demons trou ter degradado a celulose mesmo na preserga da $2 D G$ f $T$ abalas 21 e 12$)$. Dos dados destas tabelas fica bem claro que o fungo não cresce quando foi usada $2 D G$ como única fonte de car bono (MC-2DG), porém quando o meio contém celulose $(1 \%)+$ $2 D G(1 \%)(M E-2 D G)$ o fungo cresce a expensas da celulose, evi... tando o uso da $2 \mathrm{DG}$, fato comprovado pela degradação da celulo se do meio. Ao que parece o Humicola sp é um mutante naturalmente desreprimió para a 2DG, porém isto contraria o fato do mesmo ser reprimido pela glicose. 


\subsubsection{Resistência a Corantes.}

Segundo PELCZAR et alii (1980) o mecanismo de ạ̃ão dos corantes derivados do trifenilmetano, entre os que se encontra o Cristal Violeta, é incerto, mas se supore que o seu efeito inibitónio é devido á interferència com os proce-.. ssos de oxidaçäo celuiar. Segundo CAPPENTER (1969) mutantes de E. colí resitentes á luz UV também são resistentes a subs tâncias quínicas oxidantes, entre elas o cristal violetaipor esta razão se pensa que a resistência à radiação está associa da com a resistência à oxidação.

os estudos para determinar a curva de resistôn cia do fungo selvagem à Acriflavina e Cristal violeta foram realizados como descrito no item 3.6.1.3.3. os resultados ob tidos são apresentados ras tabelas 13 e 14 .

Os mutantes resistentes a 15 e 50 pg de Cristal Violeta/ml de MC foram ensajados juntamente com a Iinhagem sel vagem para verificar a sua nesistência em concentrações de 5; $10 ; 15 ; 50$ e $70 \mu g / \mathrm{ml}$ não havendo crescimento em qualquer das concentracoes ensaiadas. O mesmo foi realizado com os mutantes resistentes a 40 e $50 \mu g$ de Acriflavina/ml em MC; estes juntamente.com a linhagem selvagem soram ensaiados em concentrações de $30 ; 40 ; 50$ e $70 \mu g / m l$ não havendo crescimento em qualquer delas. Estes resultados demostraram que a resistência da lirhagem selvagem ao Cristal Violeta era de $5,0 \mu \mathrm{g} / \mathrm{ml}$ e para Acriflavina de polo menos $30 \mu \mathrm{g} / \mathrm{ml}$. Estes valores de resistência são razoáveis pois segundo PELCZAR et alii (1980) o Cris- 
ta]. Violeta em concentração de $100 \mu g / m l$ é ietal para os gêneros Monilia e Torula, enquanto que a concentraçõo de $2 \mu g / m I$ é inibitória. Porém, segundo o mesmo autor os corantes derivados da Acridina; entre eles a Acriflavina, possuem pouca aça antifúngica ficando comprovado por uma resistência do Humicola bem maior para este corante. Não foram obticios mutantes resistentes para estes corantes, porém estes dados foram aproveita-. dos para a introducão de uma marca de resistencia ros mutantes alixotrófícos.

4.3.4 Mutantes Auxotrósicos.

O isolamento e caracterizaçăo de mutantes auxotróficos foi ralizado segundo as técuicas descritas no item 3.6 .1 .4$.

Wo presente trabalio anelisaram-se 790 colonias irradiadas e que foran transferidas para mM, porém não se encontraram mutantes alixotróficos. Deviòo à dificuldade em se ob ter este tipo de marca genética procedju-se a trabalnar com mutantes auxotroficos obtidos e gentilmente cedidos por MACEDO (1986) mas que foram caracterizados no presente trabalho. os quatro mutantes auxotróficos apresentaram bom crescimento em MMH+Caseina Hidrolisada e crescimento razóvel em MMH+Extrato de Levedura (tabela 25). For estes resultados verificou-se que os 4 mutantes eram deficientes. em aminoácidos. Ensaiados em todos os aminoácidos individualmente, um deles, o mutante 1, se mostrou deficiente em arginina, sendo denominado de arg $i$. Os outros três mutantes se mostraram deficientes na sintese do á- 
cido glutâmico ou glutamina, em asparagina e em menor grau em ácido aspártico. Estes mutantes foran denominados de glu_l, glu_2, e glu.3 (mutantes 2,3 e 4 respectivanente). BERTOLDI \& CATEN (1975), também em Humicola, obtiveram mutantes auxotróficos deficientes na sintese de aminoácicos (lisina, arginina e metionina) e vitaminas (piridoxina).

Dos estudos de resistência, dost mutantes auxotróficos em $\because \mathrm{C}$ (tabela 16e 17), ao benlate, acriflavina e cris tal violeta soi visto que os mutantes 1 e 4 ten resistencia aos mesmos compostos e concentraças. Já o mutante 1 se comple menta com o 2 e 3. Assim foram escolhidos o 1 e 3, devido t que complementam as suas marcas auxotróficas e de resistencia, para serem astudados quanto a sua resistencia em MM (Tabela 18 ). os isolados ${ }_{1}$ e $1_{2}$ " do mutante 1. provém de placas àe Cristal Violeta $5 \mu g / m 1, I_{3}$ de benlate 0,4 yg/ml e 1 de benlate 0,5 $\mu \mathrm{g} / \mathrm{ml}$; os isolados $3_{1} \approx 3_{2}$, do nutante 3 , provén de Cristal Violeta $10 \mu \mathrm{g} / \mathrm{ml}, 3_{3}$ e $3_{4}$ de Cristal Violeta $5 \mathrm{fg} / \mathrm{ml}$. Dos resul tados obtidos (tabela 18) pode-se pensar que para rins de fusão de protoplastos poderiam ser utjlizados os isolados $3_{1}$ ou $3_{2}$ e $I_{3}$ ou $1_{4}$ que além de complementar suas inarcas de auxotrofia con plementam a sua resistência. Os dois primeiros isolados resistem 4,0 $\mu g$ de Cristal Violeta/ml de MMr e $0,3 \mu g$ de Benlate/ml de MMH enquanto os dois últimos resistem $2,0 \mu g$ de Cristal Vio leta/ml de MMH e 0,5 jg de Benlate/ml de MMH. Desta forma poderiam ser selecionados produtos de fusão em $M M H+C V 4,0 \mu \xi / m I+$ Benlate $0,5 \mu \mathrm{g} / \mathrm{ml}$. Porèm, seria conveniente passar esses isola 
dos por mais um cislo de seleção com finalidade de estabilizar suas marcas de resistência.

As mutaçöes que deterninan auxotrefia poden provo car ganho, perda ou näomalteração na produção de metabólitos: havendo, na iteratura, abundantes exemplos de todos estes caSOS (SERMONTI, 1969; DEMAIN, 1973; HOPWOOD \& MERRICK, 1977). Porém, os mutantes auxotróficos são por si próprios interessan tes para o melhoramento de linhagens, tendo em vista o uso cada vez maior de técnicas de recombinação que utilizam estes mu tantes como narcas genéticas.

Tabela 8. Sobrevivência do Humicola sp ęlvagem ao fungici da Benlate.

\begin{tabular}{c|c} 
Concentragáo do & $\begin{array}{c}\text { Média do diâmetro } \\
\text { denlate (uglmi) }\end{array}$ \\
\hline 0,0 & 4,0 \\
0,1 & 4,0 \\
0,2 & 4,0 \\
0,3 & 3,3 \\
0,4 & - \\
0,5 & - \\
0,6 & - \\
0,7 & - \\
0,8 & - \\
0,9 & - \\
$i, 0$ & -
\end{tabular}

(-) sem crescimento. 
Tabela 9 . Sobrevivência do Humicola sp selvagen ao rungicida Benlate.

Concentrạ̃̃c dó Beniate $(\mu \mathrm{g} / \mathrm{m} \lambda)$ $\frac{\text { Mécia do diametro das Colónias (cm) }}{24 \text { horas } 48 \text { horas } 72 \text { horas }}$

\begin{tabular}{l|l|l|l}
\hline 0,00 & 2,40 & 5,15 & 8,25 \\
0,10 & 2,30 & 4,80 & 7,80 \\
0,20 & 2,10 & 4,75 & 7,35 \\
0,30 & 1,40 & 2,75 & 4,35 \\
0,32 & 0,80 & 1,50 & 2,25 \\
0,34 & 0,25 & 0,50 & 0,90 \\
0,36 & 0,30 & 0,50 & 0,70 \\
0,38 & - & - & - \\
0,40 & - & - & -
\end{tabular}

- sem creacimento

Tabela 10. Aumento de Resistercia a Benlate a partir de duas colonias (A e B) resistentes a 0 , $1 \mathrm{~kg}$ de Eentate/mi de $M C$.

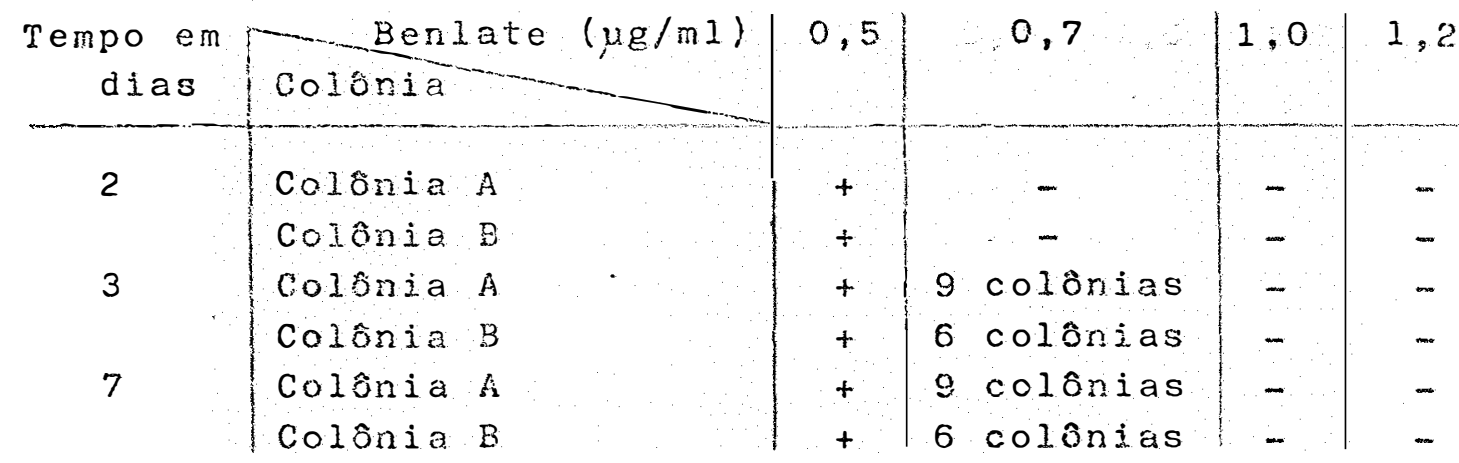

+ Crescimento que ocupou a placa toda.

- Sem crescimento. 
Trabela 12. Resistência do Humicola sp selvagem à 2-Deoxiglicose.

\begin{tabular}{c|c|c|c}
$\begin{array}{c}\text { Tempo } \\
(\mathrm{dias})\end{array}$ & $\mathrm{MC}-2 \mathrm{DG}$ & $\mathrm{ME}$ & $\mathrm{ME}-2 \mathrm{DG}$ \\
\hline 2 & - & + & - \\
6 & - & + & +
\end{tabular}

- Sem crescimento

+ Com crescimento e degradaça de celulose

Tabela 12. Resistêrcia à 2-Deoxiglicose cio Humicola sp selvagem e de colônias previamente crescìas em meio com 2-Deoxiglicose.

\begin{tabular}{l|c|c|c|c|} 
Tempo \\
(dias)
\end{tabular}

- Sem crescimento

+ Com crescimento

* Com crescimento e com degradacto de ceiujuse

col.2DG Colonia que proven do meio celulose 1\%+2DG $1 \%$ do experimento anterior.

Selvagem, Humicola sp selvagem

MC Meio Completo (Portecorvo, 1953)

ME Mejo E com Celulose (1\%)

MC-2DG Meio Completo no qual foi substituida a glicose pela 2DG.

ME-2DG Meio E com Celulose $(1 \%)+2 D G(1 \%)$. 
Tabela 13. Curva de Resistência da linhagem selvagem á Acriflavina.

\begin{tabular}{|c|c|c|c|c|}
\hline \multirow[b]{2}{*}{$\begin{array}{c}\text { Concentraçäo } \\
(\mu g / m l)\end{array}$} & \multirow{2}{*}{\multicolumn{2}{|c|}{$\begin{array}{l}2 \\
\text { Diâmetro } \\
\text { Colônia }\end{array}$}} & \multicolumn{2}{|c|}{8} \\
\hline & & & Semeacura & $\begin{array}{l}\text { Diâmetro } \\
\text { Colonia }\end{array}$ \\
\hline 0,0 (controle) & + & $6,7 / 6,4$ & + & $9,0 / 9,0$ \\
\hline 3,0 & + & $7,4 / 7,6$ & $\div$ & $9,0 / 3,0$ \\
\hline 4,0 & + & $7,0 / 6,8$ & + & $0,0 / 9,0$ \\
\hline 5,0 & + & $7,3 / 7,5$ & + & $9,0 / 9,0$ \\
\hline 6,0 & + & $6,5 / 6,4$ & + & $9,0 / 9,0$ \\
\hline 7,0 & + & $6,6 / 5,7$ & + & $9,0 / 9,0$ \\
\hline 8,0 & + & $5,7,4,3$ & + & $9,0 / 9,0$ \\
\hline 9,0 & + & $4,2 / 3,0$ & + & $0,0 / 9,0$ \\
\hline 10.0 & + & $5,5 / 4,7$ & + & $9,0 / 9,0$ \\
\hline 15,0 & + & $3,8 / 0,8$ & + & $\varepsilon, 0 / 9,0$ \\
\hline 20,0 & + & $3,0 / 3,5$ & + & $6,5 / 7,0$ \\
\hline 25,0 & + & $1,6 / 0,6$ & + & $0,0 / 0,0$ \\
\hline 30,0 & + & $0,9 /=$ & + & $5,6 / 7,0$ \\
\hline 40,0 & $+1-$ & $-10,6$ & $4 \mathrm{col}$. & $4,5 \% \cdots$ \\
\hline 50,0 & - & $-1-$ & $1 \operatorname{col} 1$. & $-1-$ \\
\hline
\end{tabular}

+ Crescimento en toda a placa

+1 - Pouco crescimento

- Sem crescimento 
Tabela 14. Curva de Resistência da linhagem selvagem ao Cristal Violeta.

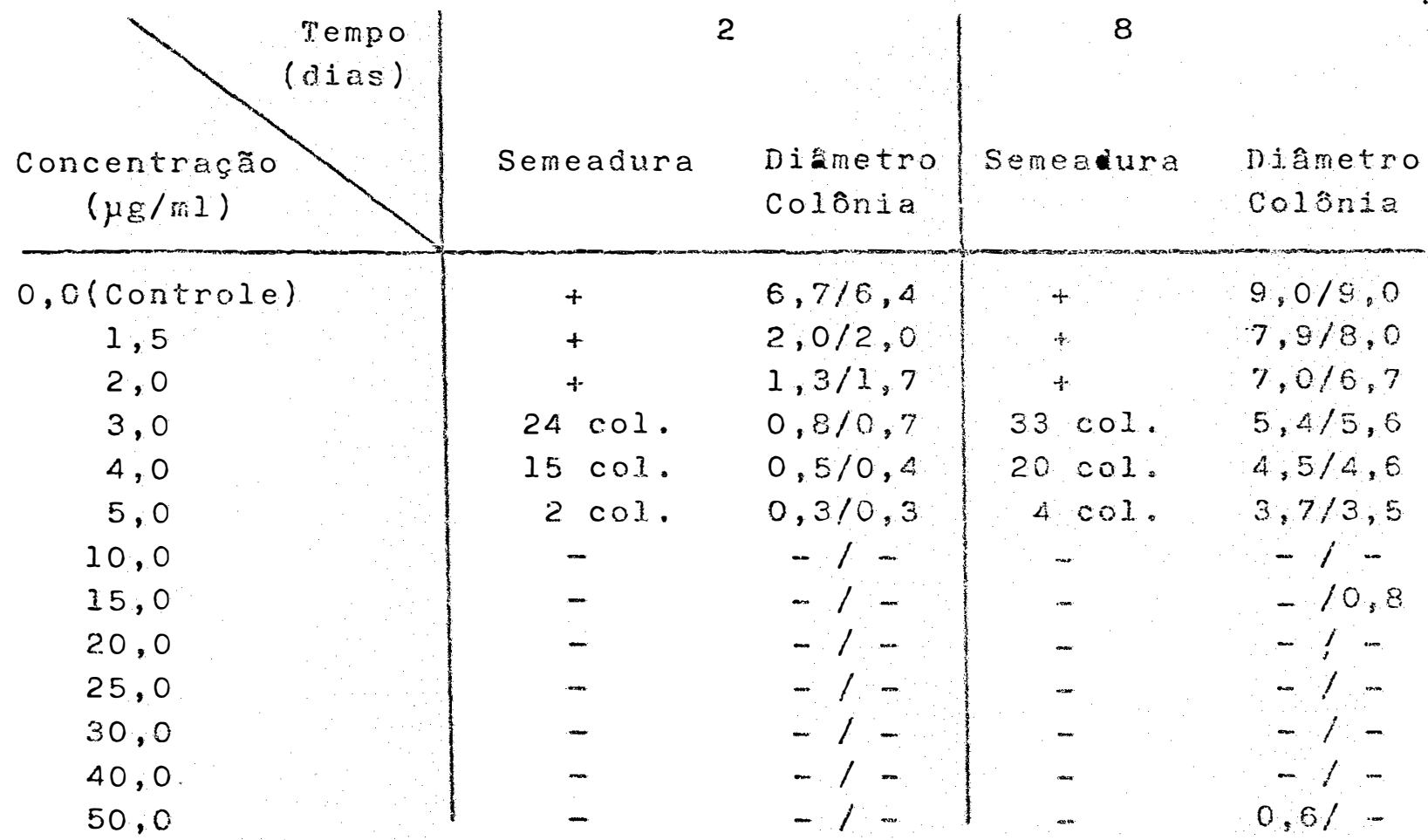

+ Crescimento em toda a placa

- Sem crescimento 
Tabela 15. Caracterização preliminar de mutantes auxotrósicos.

Mutantes MC MMH MMH $\mathrm{MHH}+\mathrm{MMH}+\mathrm{MMH}+$

E.Lev. C.Hidrol. Vitam. AC.Nuc.

\begin{tabular}{llllllll}
\hline 1 & +++ & - & + & ++ & - & - \\
2 & +++ & - & + & ++ & - & - \\
3 & +++ & - & + & ++ & - & - \\
4 & +++ & - & + & ++ & - & -
\end{tabular}

$\begin{aligned}++ & \text { Crescimento vigoroso } \\ ++ & \text { Bom crescimento } \\ + & \text { Crescimento razoavel } \\ + & \text { Sem crescimento }\end{aligned}$

Man Meio Mnino para liumicole sp $M M H+E$.Lev. MWH+Dxtrato de Levedura $M M H+C . H i d r o l . M M+C a s e j n a$ Hidalisada MMH+Vitam, MnH+Viteminas MHAC.Nuc. MMH+Addos Nucjejoos 
Tabela 16. Resistência dos mutantes auxotróficos ao Benlate, Acriflavina e Cristal violeta em Meio Completo.

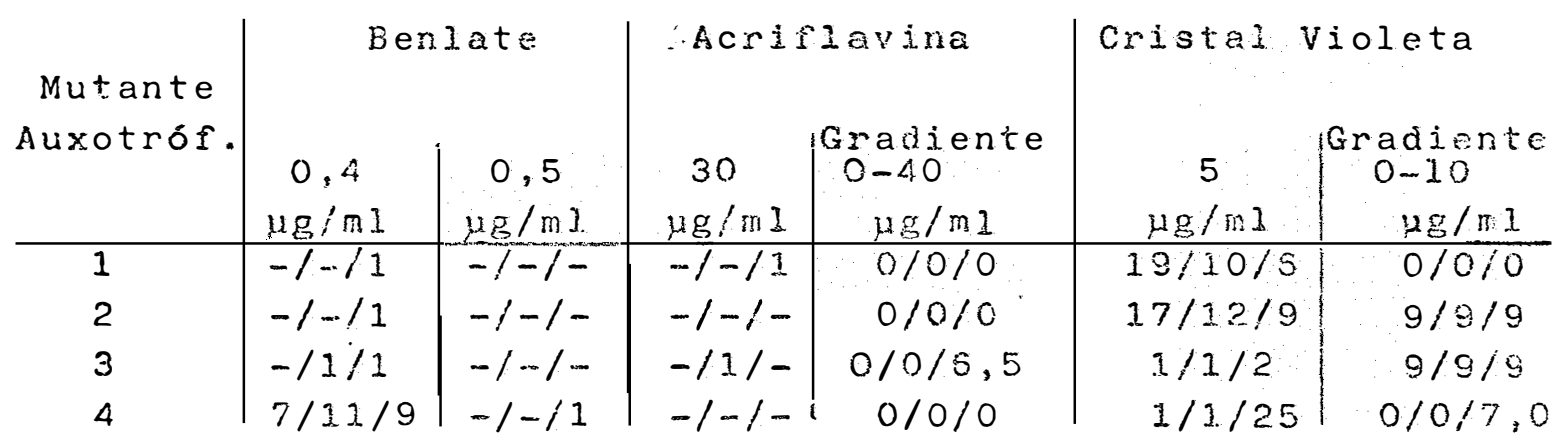

- Sem crescimento

No. Número de colonias na placa

Placa em Graciente : O número indica a distâcia a partir do zero en gue se encontravan as colonias.

Tabeia 1 . Fesistênsia dos mutantes aurotroficos ao Ben late, Acriflavina e Cristal Violeta em Meio Completo.

\begin{tabular}{|c|c|c|c|c|}
\hline $\begin{array}{l}\text { Mutante } \\
\text { Auxotrof. }\end{array}$ & $\begin{array}{l}\text { Benlate } \\
0,4 \mu g / m l\end{array}$ & $\begin{array}{l}\text { Benlate } \\
0,5 \mu \mathrm{g} / \mathrm{ml}\end{array}$ & $\begin{array}{l}\text { Acriflavina } \\
\quad 30 \mu g / m l\end{array}$ & $\begin{array}{c}\text { Crista] violeta } \\
\text { Jo } \mu g / n 1\end{array}$ \\
\hline 1 & $++t$ & +++ & $+t$ & $\ldots$ \\
\hline 2 & - & - & - & + \\
\hline 3 & - & - & + & ++ \\
\hline 4 & +++ & +++ & + & - \\
\hline
\end{tabular}

$\begin{aligned}- & \text { Sem crescimento } \\ + & \text { Pouco crescimento } \\ ++ & \text { Bom crescimento } \\ ++ & \text { Crescimento abunaante }\end{aligned}$




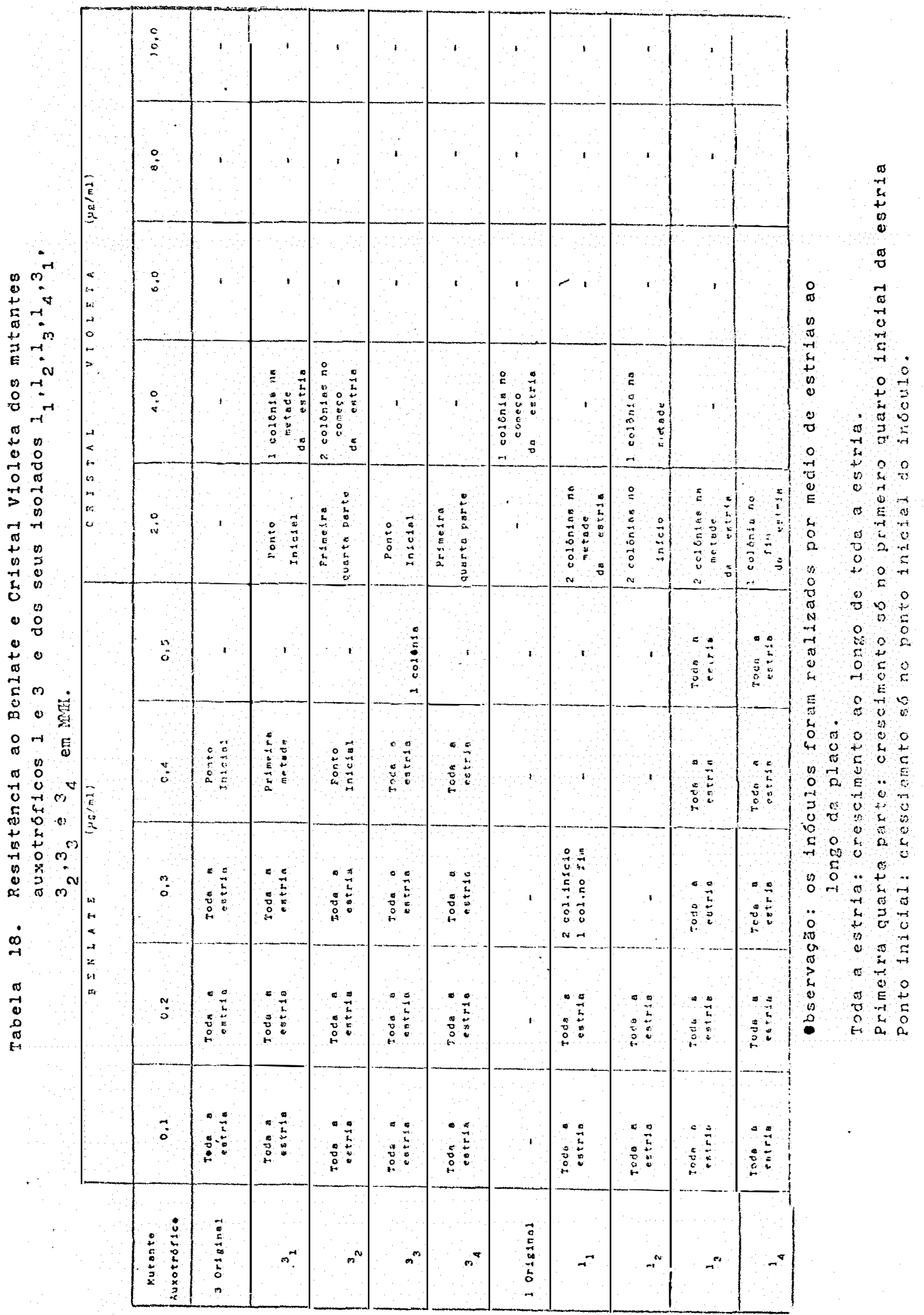




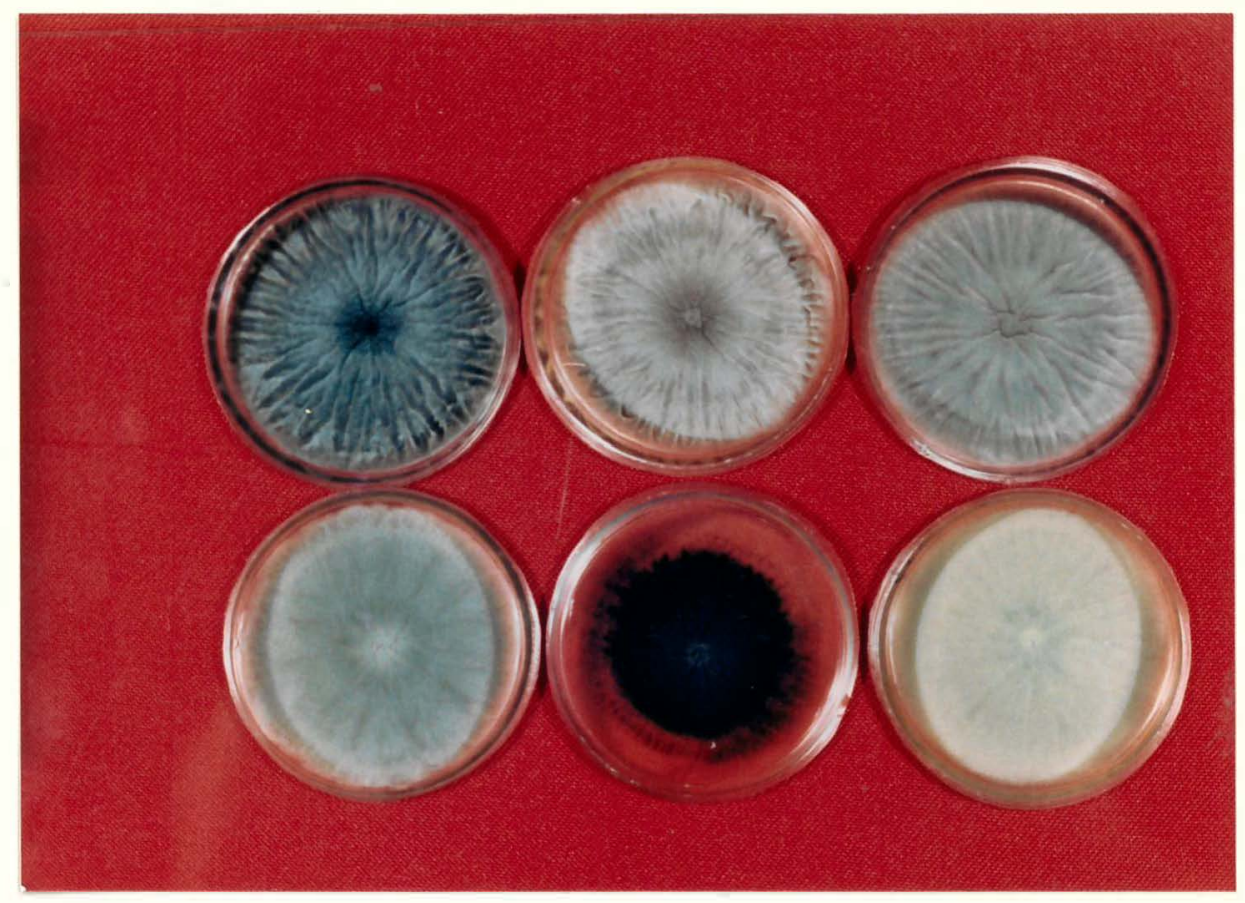

Fig. 12. Mutantes morfológicos obtidos após irradiaçäo ae protoplastos de Humicola sp com luz UV. 


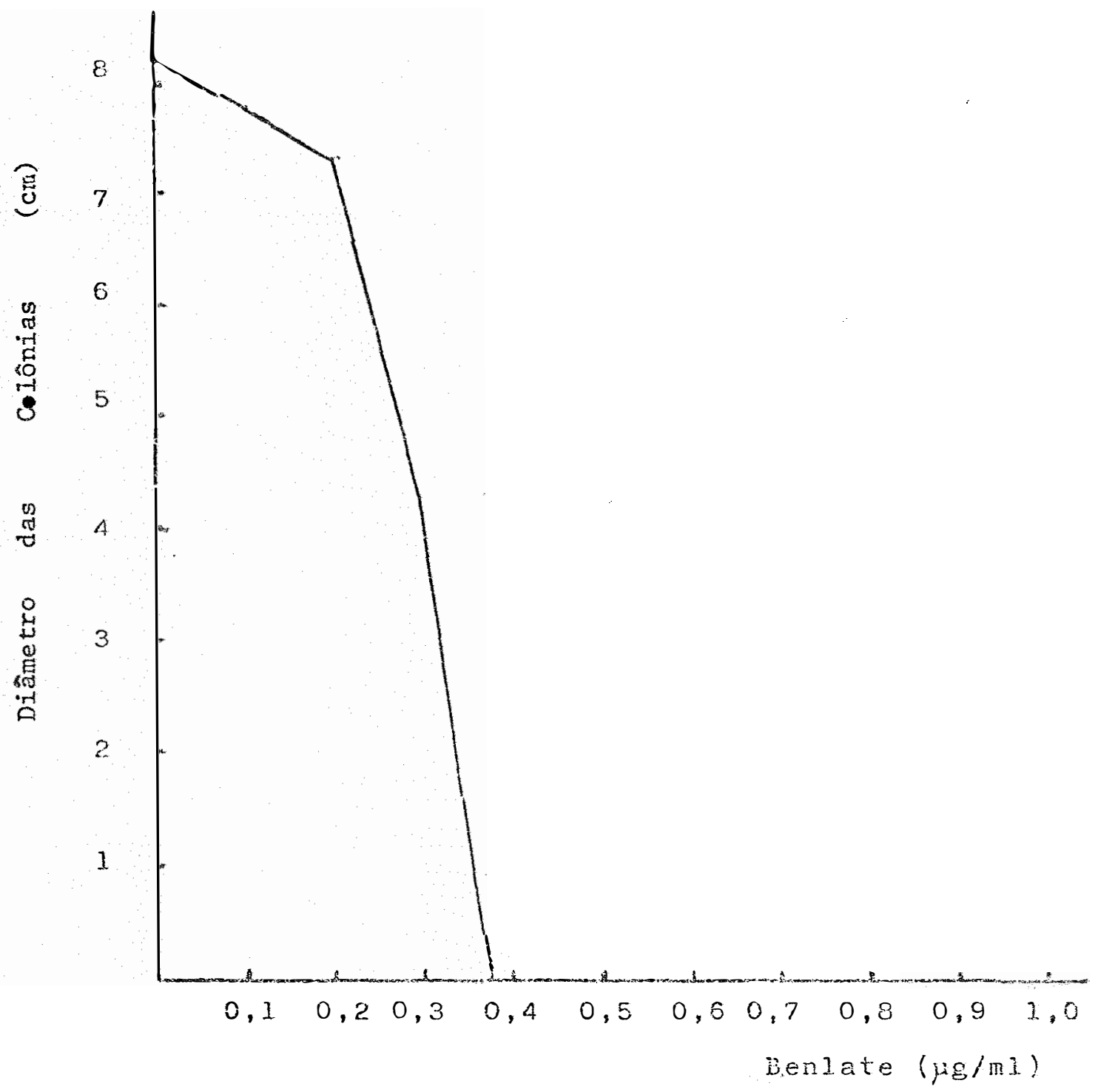

Fig. 13. Curva de Sobrevivência do Humicola sp selvagem ao fungicida Benlate. 
4. Seleção de variantes para naior produçâo de enzimas celuloliticas.

4.4.1 Sistema de Seleção em Placa.

No primeiro ciclo de seleção, os resultados mostraram diferença significativa, Tukey $1 \%$, entre as 300 colônias ensaiadas (Tabela 19), selecionando-se a variante número 4 por apresentar a melhor média do indice de ativida de enzimática. Só cinco das 100 colonias ensaiadas apresertaram diferenca significativa para repicagens dentro de com lônia motivo pelo que foi eliminada a repetição dentro de cada placa nos ciclos sucessivos.

No segundo ciclo näo houve diferenga signifi cativa entre as colónias dentro de cada um dos 3 tratamen... tos (I, NI T $(T a b e l a 20\}$. Porém, nouve aumento de producấo revelado pelo incremento do valor do indice de atividade en zimática, já que I e NI diferiram significativamente de $T$ (variante 4 do cicio anterior) (Tabela 22 , Teste de Tukey). Isto indica que os tratamentos I e NI como um todo melborá-. ran, mas que dentro de cada tratamento qualquer colônia é igual. Neste ciclo foi selecionada a variante 27 do trata mento I, pois foi a que apresentou melhor média do índice de atividade enzimática.

No terceiro ciclo não houve diferença signifi cativa entre os 3 tratamentos $I, N I$ e $T$ ( Tabela 22, Teste de Tukey) nem entre as colónias dentro de cada um dos tratamentos (Tabela 21). A variante 1 do tratamento I roi selecio 
nada en função da sua melhor média para o índice de atividade enzinática.

\subsubsection{Dosagem Enzimática.}

Dos resultados obtidos na dosagem da atividam de total de celulase extracelular (FPA) para a escolha do meio de produção de celulases (Tabela 23; fig. 14 ) foi comprovado que o meio $E($ jtem 3.2 .11$)$ desenvolyido no presente trabalho (item 3.4.1) foi o mais apropriado para a producão e ou liberação de enzimas por parte dos fungos ensaiados lMumicola sp selvagem, Hundcola sp variante 4 e Trichoderma reesei 0Mo414) já que todos eles apresentaram maior atividade enzinática nes te meio que no mejo de PETreRSON et alii (1963). Baseados ne sses resultados esse neio fol entro utilizabo para realizar a losagem da atividade enamatica oom o Humicola sp selvagem e as variantes escolhidas no processo de seleção.

Os resultados da dosagem da atividade total de celulase extracelular das variantes selecionadas ( $\mathrm{xabela} 24$ e fig.15) assim como as análises estatisticas dos mesmos (Tabela 25) mostraram que com 12 horas de incubação nầ há diferenças significativas entre as 4 variantes (selvagem, 4, 27 e 1). Com 24 h०ras, as variantes 1,4 e selvagem apresentaram diferencas significativas da 27 (Tukey $2 \%$ ). Com 36 horas a variante I mos troumse diferente da linhagem selvagem e 4 (Tukey 1\%), mas não da 27 . Com 48 horas as variantes 2 e 27 difereneiaram-se da 4 e do selvagem, mas 1 e 27 não foram diferentes entre si. A par tir dos dados da dosagem da atividade enzimatica, foram calcu- 
ladas as regressões polinomiais ( $f i g .16$ ) que estabelecem as funçôes que relacionam a atividade enzimática de cada uma das variantes estudadas em função do tempo.

4.4.3 Incremento da Produção de Enzimas Celuloliticas.

os resultados da dosagem da atividade enzimáti ca confirmaram os resultados da seleção em placa e todos eles indicaram que houve aumento significativo da produção de enzimas celuloliticas co primeiro para o segundo ciclo, mas não do segundo para o terceiro. Segundo MONTENECOURT et alij (1980) a superprodução de celulases pode ser resultado da capacidade de supersintese ou de uma maior capacidade de exportação das paoteinas; assim dojs fatores poderian ser os responsáveis desse aumento da produçăo. Um deles poderia ser simplesmente a proto plastização do fungo. Os protoplastos durante a sua regereraca sintetizam e liberam sobre a sua supericie todos os constituintes quimicos da parede celular, embora eles podem ser produzidos em quantidades diferentes daquelas encontradas nas celulas normais (BENITEZ et alii, 1975; FAKKAS \& SVOBODA, 1980). Segundo VILiARUEVA \& GARCIA ACHA (1972) com frequência a parede formada na superície do protoplasto durante a sua regene ração não é estruturalmente idêntica á parede da célula normal. indicando a formaçăo de algum tipo de parede aberrante. Todas estas alterações a nível da parede,ocasionadas pela protoplasm tização poderiam alterar a permeabilidade provocando um aumento na exportação da enzima. A mutação induzida pela irradiação com UV pode ser o outro fator responsável desse aumento da pro 
dução, podendo aumientar, a capacidade de sintese enzimática ou a capacidade de exportaçäo dessas enzimas devido a alteraços na parede e ou na membrana celuiar. A sintese da nova parede está sob estrito controle genético podendo ocorrer mutações. que se manifestariam no produto final da parede em regeneragão (PEBERDY \& FERENCZY, 1985). Também os mutantes com permeabili dade de parede e ou membrana alterada permiten um incremento na exportaçåo de produtos exibindo un inoremento na produçäo (SAUNDERS \& SAUNDERS, 1987). Assim mutantes de Penicillium chrysogenum, resistentes a antibióticos poliênicos (que atuan a nivel de nembranal, tem sido utiljzados para increnentar o titulo de penjcilina (IUENGO et alii, 1979); também em Streptomyces fradiae mutantes resistentes a infeçấo fágica: devido a alteraçöes na membrana celular, apresentam título de antibiótico elevado (PERIMAN \& HALL, 1976). Mas outros tipos de mutantes tem influido no aumento de producão; assin GOULDEN \& CHATTAHAY (1969) demonstraram que um mutante, àe alta producäo de p. chrysogenum era menos sensivel a inibiça pelo produt înal, a valina, que uma linhagem de baixa produgâa. Mutantes morfológicos de I. reese que a linhagem paxental e com alto grau de ramificacão a rasen taram evidente aumento no indice de atividade celulolitica (FARKAS et alii, 1981), também BROWN et alii (1987b)concluiram que o aumento na produção de $\beta-g I j \operatorname{cosidase~ocorrido~num~mutan-~}$ te de penicillium pinophilum deviurse ao fato de apresentar um micélio mais ramificado mas com hifas mais largas o que aumentava a área de secreção de enzima. DHAR \& KHAN (197i) \& MORRISON \& RIGHELATO (1974) encontraram que mutações que afetam a forma de crescimento das hisas de P. chrysogenum 
em cultura submersa, foram importantes na fermentação da peni cilina pois melhoraram a aeraça e a eficiência na utilizaça de precursores. Talvez o aumento constatado no Humicola sp po deria dever-se a alguma destas mutạ̧ôes ocasionando já sea um aumento na exportaça ou um verdadeiro aunento na produçãc en zimática.

De acordo com os dades das distribuições de frequência dos valores do frodice de atividade enzimática dos três ciclos de seleção apresentados (Tabela 26) verifica-se que há um aumento no valor do desvio padra do primeiro ciclo para o segundo da ordem das dez vezes, quase o dobro do incre mento ocorrido no terceiro ciclo e percebe-se tanben que o au mento em I sempre maior qus en ivi. o vajor de cuntose diminuiu en quase dez vezes no segurdo cjojo e um pouco menos no terceiro, também há uma aiminujgão no valor de assimetria, is to se traduz nos segundo e terceiro ciclos em curvas assina tricas igual ao primeiro ciclo, mas com pendentes mais modera das ( $f i g .17$ e 18). Todo isto indica que há uma maior heteroge reiàade dos dados dos cjclos 2 e 3 em comparaçăo com o prime ro ciclo, porém, no segundo ciclo o aumento de variabilidade é maior que no terceiro ciclo. Isto poderia dever-se ao fato de que ao selecionar a melhor variante de cada ciclo se esta homogeneizando, reduzindo a variabilidade genética do próximo ciclo; além disso, a variante 27 selecionada no segundo ciclo poderia ser mais resistente á radiaçấo portanto a dose de UV ministrada no terceiro ciclo não teria provocado uma alteraçầo genética tal que provocara um aumento da variabilidade da mes 
ma inagnitude que o produzido no ciclo anterior. Os resultados mostram também que o aumento da variabilidade é maior em $I$ que em NI indicando que a radiação é um processo efetivo para incrementar a variabilidade, o que resulta indispensável para. uma posterior seleção (SERMONTI, 1969; SILVA \& AZEVEDO, 1978 ). Também BARACHO \& FERRĂO (1983) explicain que o aumento na varia bjlidade genética encontrada no Aspergillus niger quanto á pro dução de ácido citrico foi, sem dúvida, uma consequência da a.. ção da luz UV, que alterou fisiologicamente os isolados de maneira diversa.

Se a irradiação fosse a responsâvel pelo aumento da produção de enzimas, a variabilidade genética induzida teria atingido um platô no segundo ciclo de seleçao pois nazo produz qualquer aumento no tercejro ciclo de seleça fato vsrificado pelos resultados da seleçấo em placa (item 4.4 .1 ) e cosagem da atividade enzimática (iteni 4.4.2). Segundo SILVA \& AZEVEDO (1978) um incremento continuo na produça de ácido crtrico, pelo A. niger, resuitaria numa estabilizaçõo da variabilidade ainda quando estimulada por agentes mutagenicos, pro vavelmente esta seria uma regra geral para qualquer caracteris tica estudada. Isto também foi verificado por ALIKHANIAN (i962) em Streptomyces para a produção de estreptomicina. Também pode ria ter acontecido que a variante 27 , selecionada no segundo ciclo, fosse mais resistente á luz UV portanto a dose de radia cão ministrada não teria sido suficiente para produzir uma nova alteração genética que provocasa outro aumento de produção no terceiro ciclo. Para isso deve-se aumentar a dose de UV ministrada necessitando-se estudar uma nova curva de sobrevivência dos protoplastos da variante 27 . 
Segundo ANDRES \& PEBERDY (1974b) Aspergilius. nidulans tem parte da sua invertase localizada externamente á membrana plasmática. os autores sugerem que esta invertase po deria encontrar-se neespaç periplásmico ou mesmo na parede celular. Forém, estudos realizados por CIBSON (1973) não reve laram qualquer localização especifica para essas proteinas na parede o que indicaria que a enzima não é parte estrutural da mesma, mas que estaria em trânsito ao exterior da célula, hipó tese apoiada por ANDRES \& PEBERDY (1974a) uma vez gue encontra ram que a maior parte da invertase é exportada pelo A.nidilans Este poderia ser o caso do Humicola sp selvagem já que a ativi dade de celulase da fração intracelular e da ligada á parede celular ("cell bond") foi cerca de 3 vezes maior que a atividade de celulase extracelular (MACEDO, 1986) o que estáde acordo com o proposto por CHAVES (1982) que sugere que a enzima 1. gada á massa celular provavelmente é extracelular e năo possui Iigação de caráter iônicu. Assim se for a proteplastização o fator responsâvel pelo aumento da produção registrado no segun do ciclo, isto se deveria a algum arranjo diferente da nova p⿳亠丷厂 rede celular. Isto aconteceria só uma vez, por isso já no terceiro cicló de seleção não houve aumento significativo de produção. Para esclarecer este fenômeno devem ser feitos estudos bioquímicos mais detalhados que permitirão saber se houve um verdadeiro aumento de produção de enzimas celuloliticas intra e extracelulares ou um aumento na capacidade de exportação e/ou permeabilidade e portanto maior exportação de enzima extracel $\underline{u}$ lar. 
No presente trabalho, através dos 3 ciclos de selecăo obteve-se um aumento considerảvel da atividade enzimática (FPA) (Tabela 27) incremento similar ao obtido por GRIGOROV et alii (1983) que também em humicola Iutea ensaiaram ciclos de seleção, com radiaçăo gamma, para produção de proteases ácidas, obtendo, do primeiro ao terceiro ciclo incrementos que foram de $160 \%$ até $200 \%$ para obter variantes que diminuiram a sua produção no quarto ciclo de selegão. Também NEVALATNEN et alii (1980) e FARKAS et alii (1982) obtiveram mutantes, por irradiaçăo com luz UV, de T- reesei que aumentaram de 2 a 3 ve zes a produç̃o de endo e exoglucanases e em até 6 vezes a de B-glicosjdase.

Tabela 19. Análise de Variancia em 19 locos a a ácaso para a variável Indice de Atividade Enzimática do prí meiro cicio de seleção.

\begin{tabular}{lrrrr} 
Causas da Variação & GI & \multicolumn{1}{c}{ SQ } & QW & $E$ \\
\hline & & $10^{-3} \mathrm{X}$ & $10^{-3} \mathrm{X}$ & \\
Blocos & 1 & 0,0031 & 0,0031 & $0,0 \mathrm{~J}$ \\
Colónias & 99 & 69,8380 & 0,7054 & $3,07 * *$ \\
Residuo (A) & 99 & 22,7012 & 0,2293 & \\
Repicagens (Colộnia) & 100 & 4,2822 & 0,0428 & 1,64 \\
Residuo (B) & 100 & 2,6012 & 0,0260 & \\
\hline
\end{tabular}

TOTAL

399

Média Gerai $=1.00$

$\operatorname{Cv}(A)=1,07 \%$

$\mathrm{CV}$ (B) $=0,51 \%$ 
Tabela 20. Análise de Varjância ern Blocos ao acaso para a variável Índice de Atividade Enzimática do Segundo Ciclo de seleção.

\section{Irradiados}

\begin{tabular}{ccccc} 
Causas da Variação & GI & SQ & QM & $F$ \\
\hline Blocos & 1 & 0,0248 & 0,0248 & 1,94 \\
Co1ônias & 49 & 0,6313 & 0,0129 & 1,00 \\
Residuo & 49 & 0,6258 & 0,0128 &
\end{tabular}

TOTAL

99

$$
\begin{aligned}
& \text { MÉdia Geral }=1,1 ? \\
& \mathrm{CV}=10,2 \%
\end{aligned}
$$

\section{Não Irradiados}

\begin{tabular}{lrccc} 
Causas da Variaçõo & $G L$ & SQ & QM & $F$ \\
\hline & 1 & 0,0014 & 0,0014 & 0,16 \\
Blocos & 49 & 0,4039 & 0,0082 & 0,94 \\
Colônias & 49 & 0,4290 & 0,0087 & \\
Residuo & 49 & & \\
\hline
\end{tabular}

TOTAL

99

$$
\begin{aligned}
& \text { Média Geral }=1,10 \\
& \text { CV }=8,5 \%
\end{aligned}
$$


Tabela 21. Análise de Variância em Blocos ao Acaso para a variável fndice de Atividade Ensimática do Tercejro ciclo de Seleção.

\section{Irradiados}

\begin{tabular}{lrccc} 
Causas da Varjaça & GL & SQ & QM & $F$ \\
\hline Blocos & 1 & 0,0018 & 0,0018 & 0,75 \\
Colônias & 49 & 0,1122 & 0,0023 & 0,96 \\
Residuo & 49 & 0,1155 & 0,0024 & \\
\hline
\end{tabular}

TOTAL

99

Média Geral $=1,03$

$\mathrm{CV}=4,8 \%$

Não Irradiados

\begin{tabular}{crccc} 
Causas da Variagazo & GL & SQ & QH & $F$ \\
\hline Blecos & 1 & 0,0002 & 0,0002 & 0,05 \\
Colônias & 49 & 0,1697 & 0,0035 & 1,13 \\
Residuo & 49 & 0,1536 & 0,0031 & \\
\hline
\end{tabular}

TOTAL

99

Mécìa Geral $=1,02$

$\mathrm{CV}=5,4 \%$ 
Tabela 22. Análj.se de Variância em Blocos ao acaso para a variável Indice de Atividade Enzimática entre os Segundo e Terceiro ciclos de seleção.

$\begin{array}{crrrr}\text { Causas da Variação } & \text { GL } & \text { SQ } & \text { QM } & F \\ \text { Blocos (Ciclo) } & 2 & 0,0863 & 0,0431 & 6,73 * * \\ \text { Ciclo } & 1 & 0,7030 & 0,7030 & 109,34 * * \\ \text { Tratamento } & 2 & 0,1209 & 0,0604 & 9,44 * * \\ \text { Cicloxtratamento } & 2 & 0,0894 & 0,0447 & 6,98 * * \\ \text { fiesiduo } & 592 & 3,8068 & 0,0084 & \end{array}$

TOTAL

599

$$
\begin{aligned}
& C V=7,5 \% \\
& * \text { Significativo } 1 \%
\end{aligned}
$$

\begin{tabular}{lccc} 
Teste de rulsey para médias de tratamentos dentro do Segundo \\
$\begin{array}{l}\text { Ciclo. } \\
\text { Tratamento }\end{array}$ & Média & $5 \%$ & $1 \%$ \\
\hline \\
Irradiado & 1,12 & $\mathrm{a}$ & $\mathrm{A}$ \\
Não Irradiado & 1,10 & $\mathrm{~b}$ & $\mathrm{~A}$ \\
Testemunha & 1,06 & $\mathrm{C}$ & $\mathrm{B}$
\end{tabular}

Médias seguidas por letras distintas são diferentes entre si ao nivel de significância indicado.

Teste de Tukey ara médias de tratamentos dentro do Terceiro Ciclo.

\begin{tabular}{lccc} 
Tratamento & Média & $5 \%$ & $1 \%$ \\
\hline Irradiado & 1,03 & a & A \\
Testemunha & 1,02 & a & A \\
Não Irradiado & 1,02 & a & A
\end{tabular}

Médjas seguidas por letras distintas são diferentes entre si ao nivel de significância indicado. 
Tabela 23. Peso seco do micélio (mg)e atividade total de celu lase extracelular (FPA) $\left(\times 10^{-5} \mathrm{IU} / \mathrm{ng}\right)$ em neio $\mathrm{E}$ e meio de PETTERSON et alii (2963).

\section{2 horas de crescimento}

\begin{tabular}{l|cc|cc} 
Fungo & \multicolumn{2}{|c|}{ Meio } & \multicolumn{2}{c}{ Meio de Detterson } \\
& $\begin{array}{l}\text { Micélio peso } \\
\text { seco (mg) }\end{array}$ & FPA $\left(\times 10^{-5}\right)$ & Micélio peso & FPA $\left(\times 10^{-5}\right)$ \\
& & & seco (mg) & \\
\hline QM 9414 & 87,0 & 20,956 & 119,5 & 10,1312 \\
H.sp.Selv. & 78,5 & 4,51305 & 77,5 & 4,6836 \\
H.sp.4 & 43,0 & 8,4622 & 43,5 & 6,45692
\end{tabular}

24 horas de crescimento

\begin{tabular}{|c|c|c|c|c|}
\hline \multirow[t]{2}{*}{ Fungo } & \multicolumn{2}{|c|}{ Mejo } & \multicolumn{2}{|c|}{ Meio de Petterson } \\
\hline & $\begin{array}{l}\text { Micélio peso } \\
\text { seco (ng) }\end{array}$ & FPA $\left(\times 10^{-5}\right)$ & $\begin{array}{l}\text { Micélio peso } \\
\text { seco (mg) }\end{array}$ & FPA $\left(x 0^{-5}\right)$ \\
\hline QW 9414 & 145,0 & 2,81788 & 230 & 1,23999 \\
\hline $\mathrm{H}, \mathrm{sp}, \mathrm{Selv}$. & 81,5 & 3,60542 & 100 & 2,85299 \\
\hline$H \cdot s p \cdot 4$ & 109,0 & 3,44904 & 152,5 & 1,67281 \\
\hline
\end{tabular}

36 horas de crescimento

\begin{tabular}{|c|c|c|c|c|}
\hline Fungo & $\begin{array}{l}\text { Meio } \\
\text { Micélio pese } \\
\text { seco (mg) }\end{array}$ & $\operatorname{FPA}\left(\times 10^{-5}\right)$ & $\begin{array}{l}\text { Meio de Pet } \\
\text { Micélio peso } \\
\text { seco (mg) }\end{array}$ & $\operatorname{PA}\left(x 10^{-5}\right)$ \\
\hline QM 9414 & 117,5 & 2,39045 & 334 & 1,64309 \\
\hline H.sp.Selv. & 81,5 & 2,81011 & 267 & 1,70778 \\
\hline $\mathrm{H} \cdot \mathrm{sp} \cdot 4$ & 88,0 & 3,09359 & 90,5 & 4,34508 \\
\hline
\end{tabular}




\section{8 horas de crescinerto}

\begin{tabular}{l|cc|cc} 
Fungo & Meio & E & Meio de Petterson \\
& $\begin{array}{c}\text { Micélio peso } \\
\text { seco (mg) }\end{array}$ & FPA $\left(\times 10^{-5}\right)$ & Micélio peso & FPA $\left(\times 10^{-5}\right)$ \\
QM 9414 & 102,0 & 2,62661 & 294,5 & 2,45263 \\
H.sp.selv. & 65,0 & 5,78378 & 113,5 & 2,55084 \\
H.sp.4 & 87,5 & 5,08668 & 83,5 & 3,72607
\end{tabular}


Tabela 24. Dosagem das variantes selecionadas.

Peso seco do micélio (mg) e atividade total de celulase extracelular (FPA) $\left(\times 10^{-6} \mathrm{IU} / \mathrm{mg}\right)$.

12 horas de crescimento

$\begin{array}{lrrr}\text { Fungo Micélio Peso seco }(\mathrm{mg}) & \text { FPA }\left(\times 10^{-6}\right) \\ \text { Selvagem } & 46,0 & 7,82975 \\ \text { Variante 4 } & 38,5 & 10,04500 \\ \text { Variante 27 } & 57,5 & 1,88200 \\ \text { Variante 1 } & 51,0 & 2,95175\end{array}$

24 horas de crescimento

Fungo Micélio Peso seco (mg) FPA $\left(\times 10^{-6}\right)$

Selvagem

Variante 4

32,5

31,855

37,5

33,366

Variante 27

63,5

11,334

Variante 1

28,0

35,8374

36 horas de crescimento

\begin{tabular}{|c|c|c|c|c|}
\hline Fungo & Micélio & Peso & seco (mg) & $\left(x+10^{-6}\right)$ \\
\hline Selvagem & & 33,5 & & 16,598 \\
\hline Variante 4 & & 35,5 & & 7,213 \\
\hline Variante 2 & & $36, \bullet$ & & 24,981 \\
\hline Variante 1 & & 33,5 & & 27,201 \\
\hline
\end{tabular}

48 horas de crescimento

$\begin{array}{lrc}\text { Fungo } & \text { Micélio Feso seco }(\mathrm{mg}) & \text { FPA }\left(\times 10^{-6}\right) \\ \text { Selvagem } & 57,5 & 7,030 \\ \text { Variante 4 } & 60,0 & 18,450 \\ \text { Variante 27 } & 58,5 & 29,265 \\ \text { Variante 2 } & 34,5 & 36,330\end{array}$


Tabela 25. Análise de Variancia en factorial da atividade total da celulase extracelular (FPA).

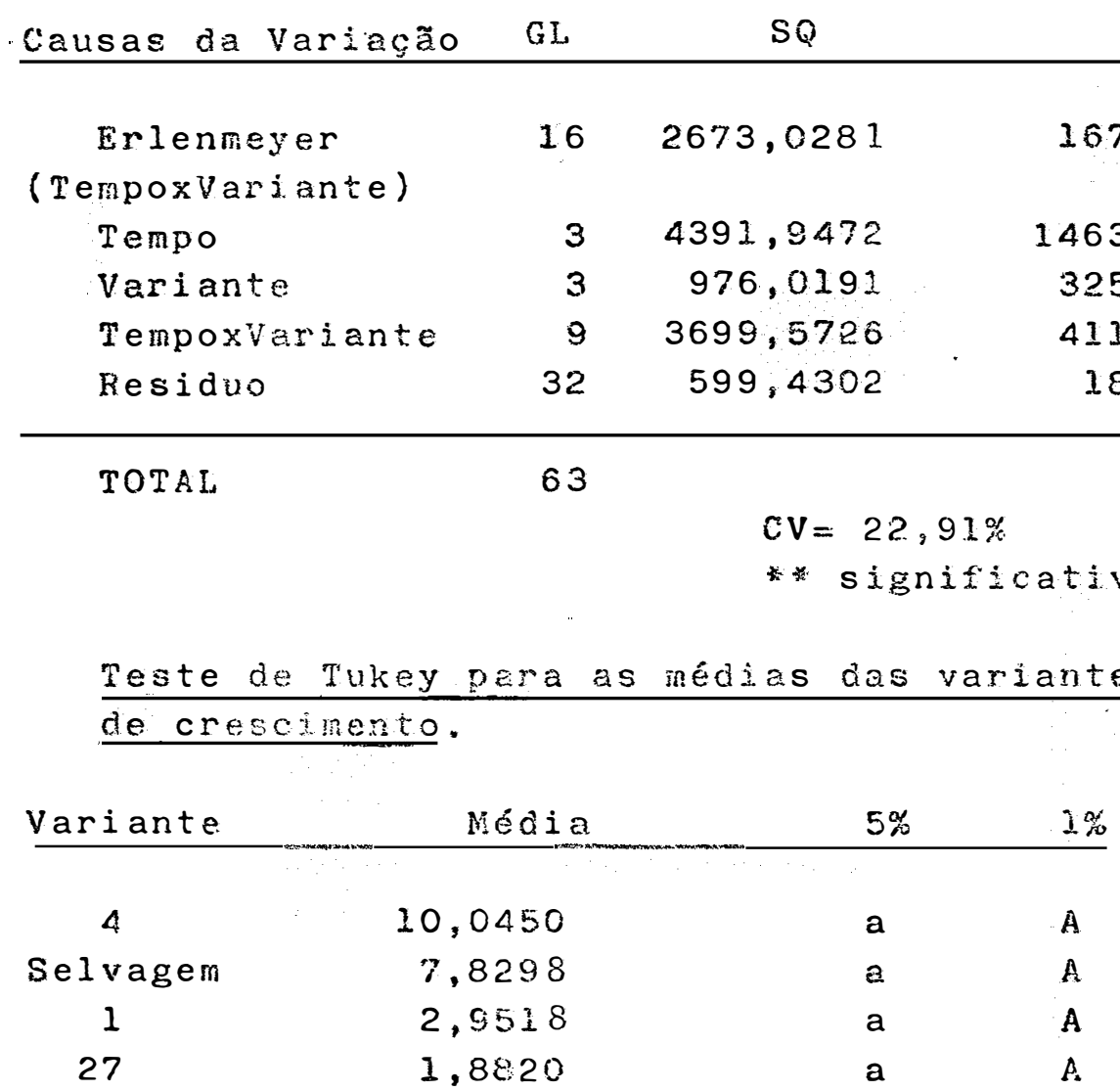

Médias seguilas por letras distintas são diferentes entre si ao nivel de significância indicado.

Teste de Tukey para as medias das variantes com 24 horas de crescimento.

\begin{tabular}{cccc} 
Variante & Médiz & $5 \%$ & 1\% \\
\hline 1 & 35,8747 & a & A \\
4 & 33,3432 & a & A \\
Selvagem & 31,8550 & a & A \\
27 & 11,3340 & b & B
\end{tabular}

Médias seguidas por letras distintas são diferentes entre si ao nfvel de significancia indicado. 
Teste de Tukey para as médias das veriantes com 36 horas de erescinento.

\begin{tabular}{cccc} 
Variante & Média & $5 \%$ & $1 \%$ \\
\hline$I$ & 27,2010 & 3 & $\mathrm{~A}$ \\
27 & 24,9818 & a & $\mathrm{AB}$ \\
Selvagen & 16,5985 & b & $\mathrm{BC}$ \\
4 & 7,2130 & $\mathrm{c}$ & $\mathrm{C}$
\end{tabular}

Médias seguidas por letras distintas são diferentes en tre si ao nível de significancia indicado.

Teste de Tukey para as médias das variantes con 48 horas de crescimento.

\begin{tabular}{cccc} 
Variante & Média & $5 \%$ & $1 \%$ \\
\hline 1 & 36,3305 & $a$ & $A$ \\
27 & 29,2657 & $a$ & $A$ \\
4 & 18,4505 & $b$ & $B$ \\
Selvagen & 7,0302 & $c$ & $\mathrm{C}$
\end{tabular}

Medias seguldas por letras distintas sấo diferentes an tre si ao nivel de significância indicado. 
Tabela 26. Estimadores estatisticos das ditribuiçôs de frequência para os valores do Indice de Atividade Enzimática para os três ciclos de seleção.

\section{Ciclo 1 Ciclo 2 Ciclo 3}

\begin{tabular}{|c|c|c|c|c|c|}
\hline & & $I$ & NI & $I$ & NI \\
\hline $\mathrm{n}$ & 400 & 100 & 100 & 100 & 100 \\
\hline$x($ Média $)$ & 1,0 & 1,12 & 1.10 & 1,03 & 1,02 \\
\hline Desvio Pacirão & 0,01 & 0,15 & 0,11 & 0,08 & 0,07 \\
\hline Variância & $0,01 \times 10^{-2}$ & 0,02 & 0,01 & 0,01 & $0,49 \times 10^{-2}$ \\
\hline $\mathrm{cV}$ & 1,57 & 13,54 & 10,30 & 8,02 & 6,60 \\
\hline Assimetria & 6,72 & 2,16 & 2] 5$, & 2,77 & 2,74 \\
\hline Curtose & 50,69 & 5,96 & 6,56 & 6,45 & 7,73 \\
\hline Moda & 3,00 & 1,00 & 1,00 & 1,00 & 1.00 \\
\hline Amplitude & 0,17 & 0,83 & 0,67 & 0,37 & 0,35 \\
\hline 100\% Máximo & 1,17 & 1,83 & 1,67 & 1,37 & 1,35 \\
\hline $75 \% \quad Q_{2}$ & 1,00 & 1,16 & 1.12 & 1,00 & 1,00 \\
\hline $50 \%$ Mediana & 1,00 & 1,08 & 1,08 & 1,00 & 1,00 \\
\hline $25 \% \quad Q_{1}$ & 1,00 & 1,00 & 1,00 & 1,00 & 1,00 \\
\hline O\% Minimo & 1,00 & 1,00 & 1,00 & 1,00 & 1,00 \\
\hline
\end{tabular}

Tabela 27. Incremento em porcentrgem da Atividade total de celulase extracelular (FPA) das variantes selecionadas em cada ciclo em relação ao selvagem.

\begin{tabular}{l|r|rrrr} 
Ciclo de & Variante & Tempo de crescimento em horas \\
Seleção & 12 & 24 & 36 & 48 \\
\hline Primeiro & 4 & 28,29 & 4,74 & $-56,54$ & 162,44 \\
Segundo & 27 & $-75,96$ & $-64,42$ & 50,50 & 316,28 \\
Terceiro & 1 & $-62,30$ & 12,61 & 63,88 & 416,78
\end{tabular}




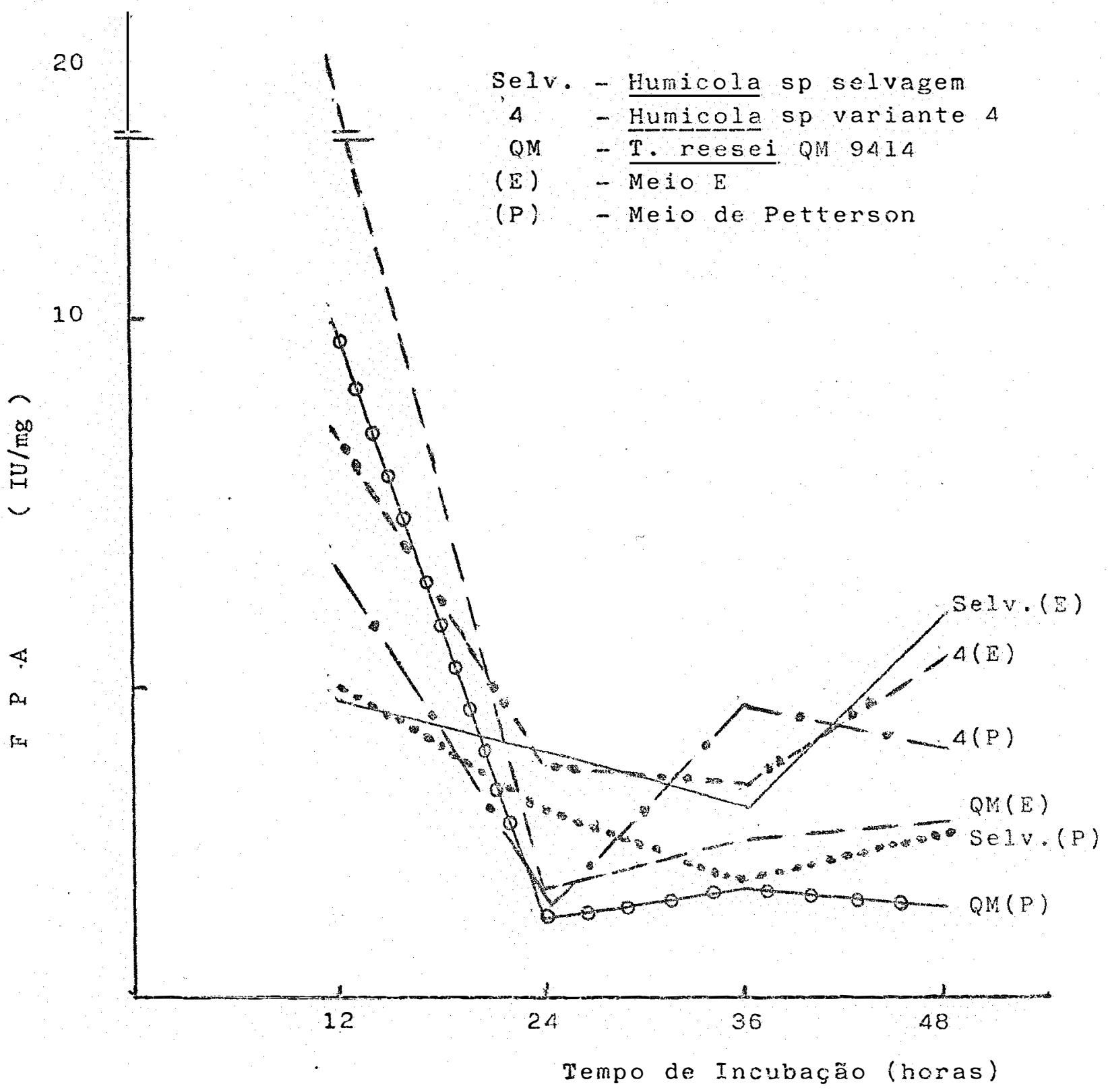

Fig.ril4. Atividade total de Celulase Extracelular na escolha do meio para produção de celulases. 


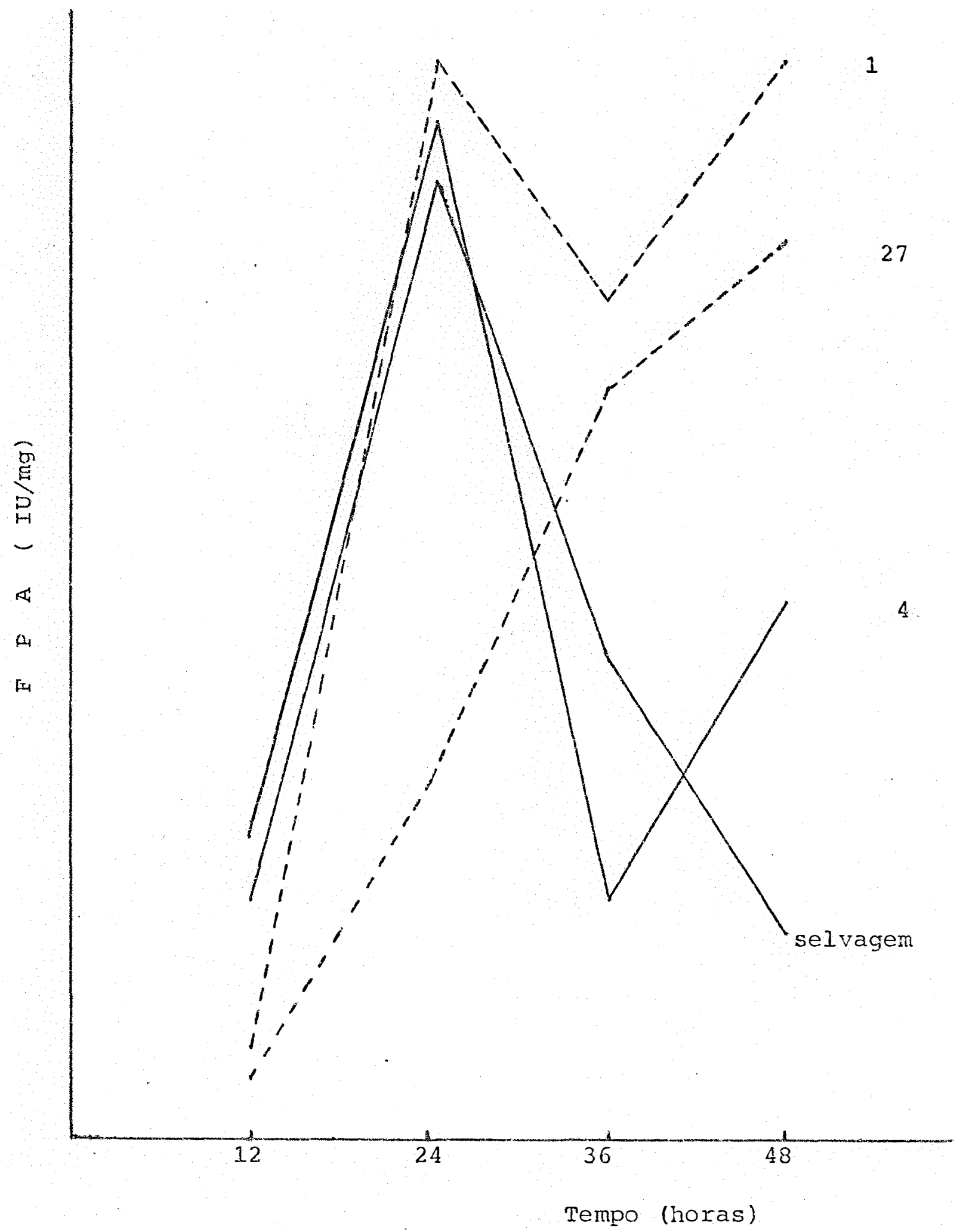

Fig. 15. Atividade total de celulase Extracelular em Humicola a sp selvagem e nas variantes selecionadas. 

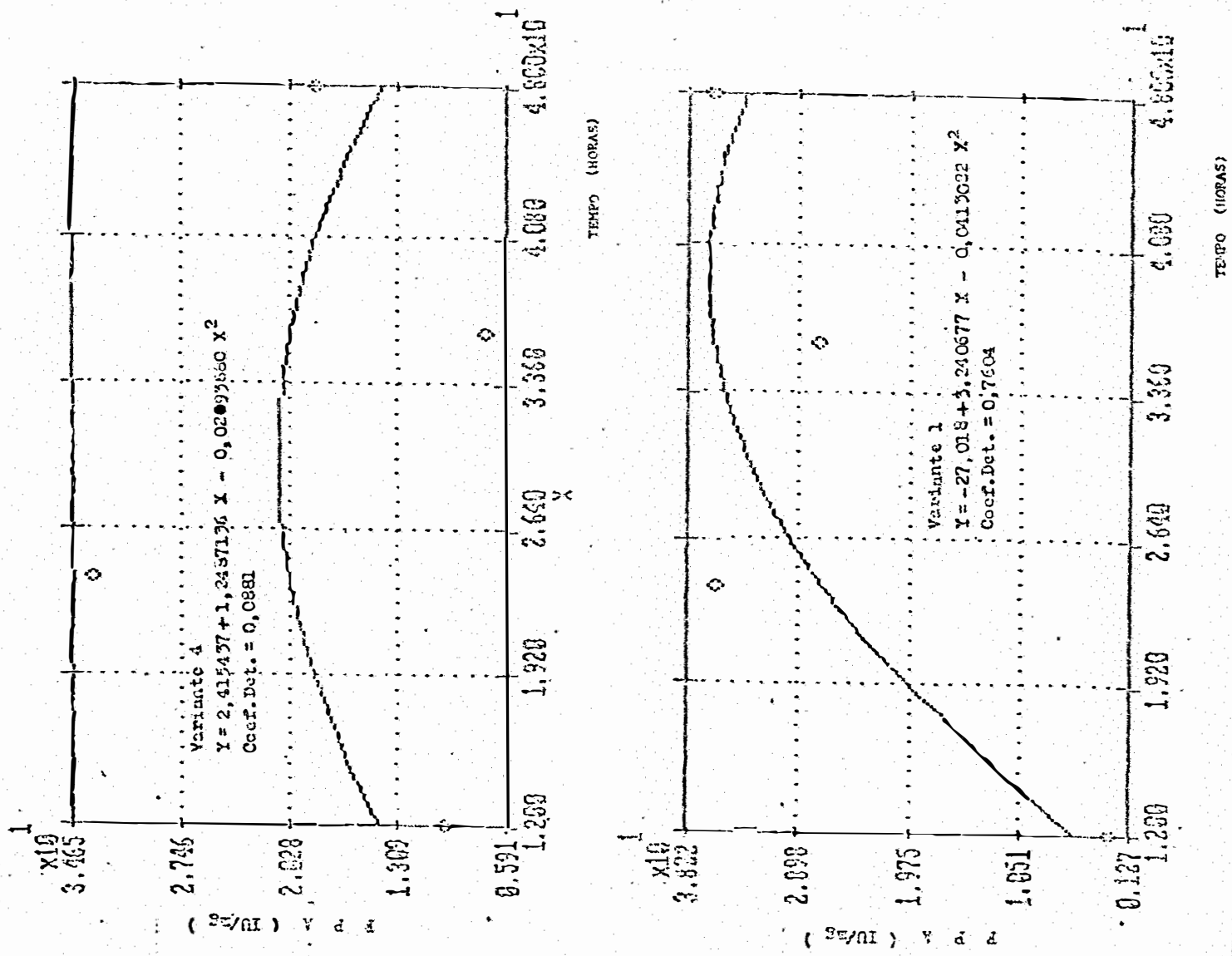

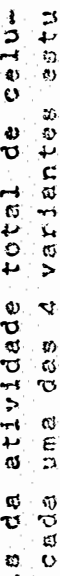
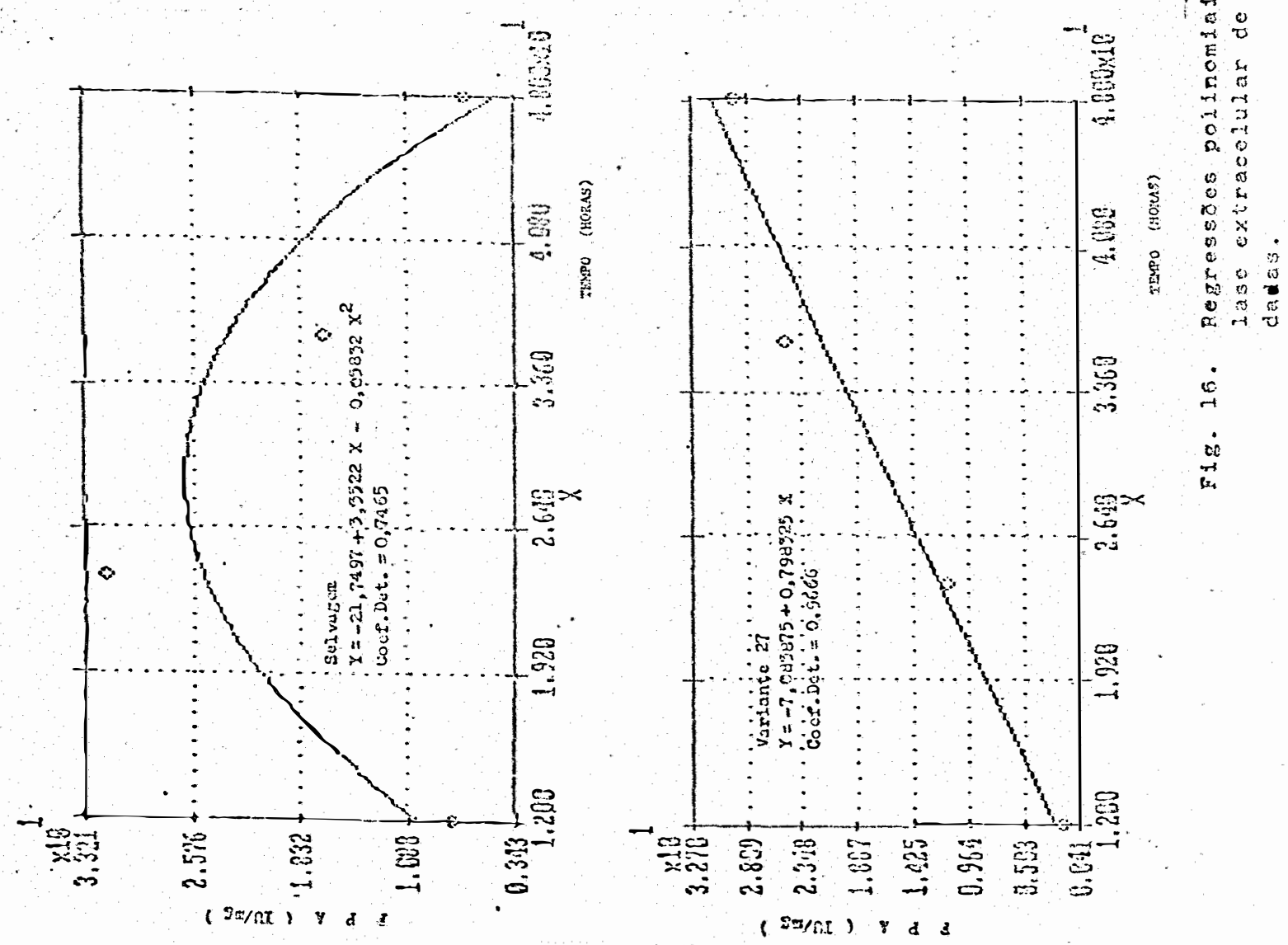


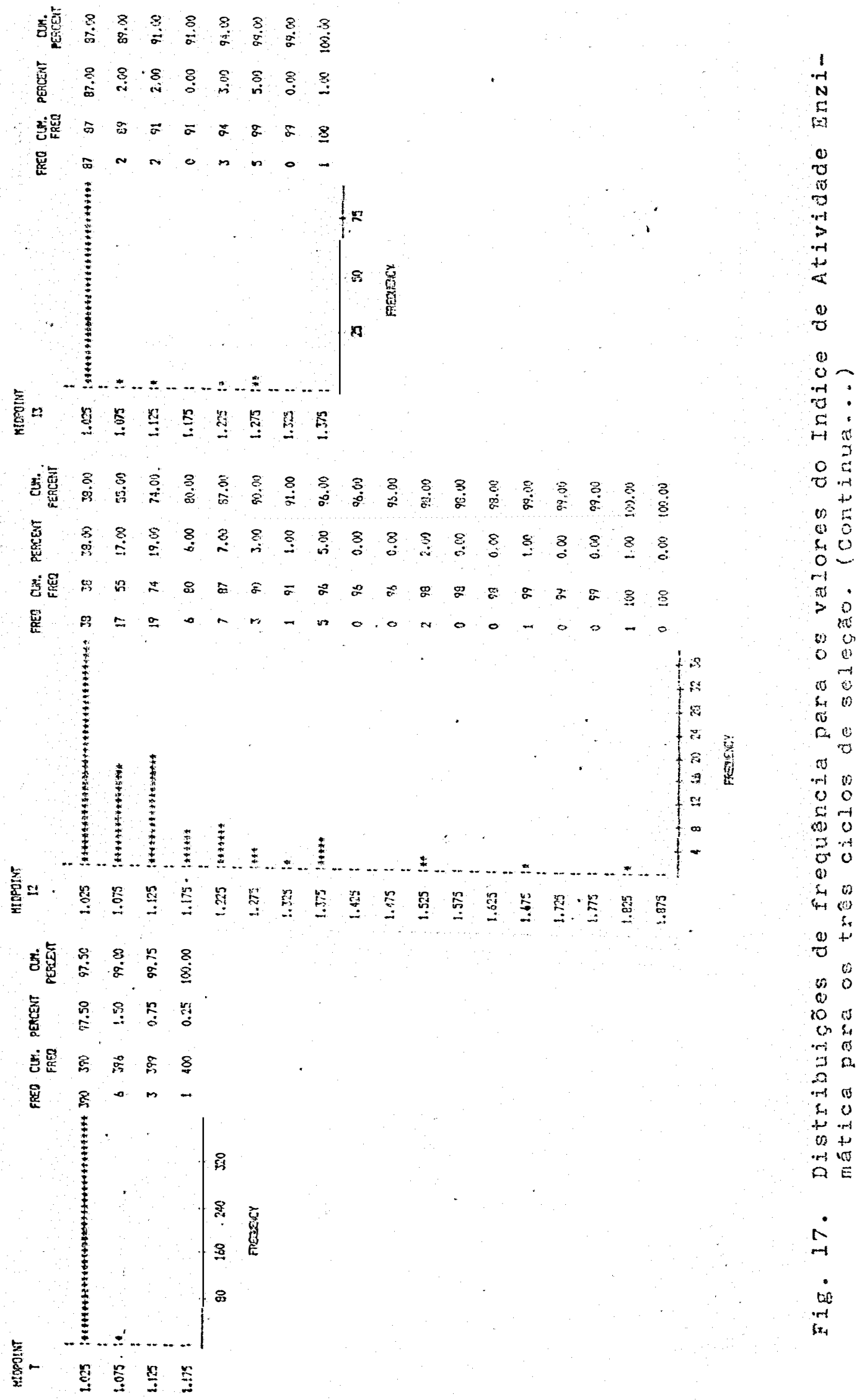




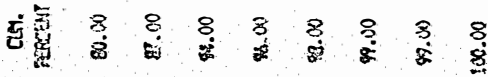

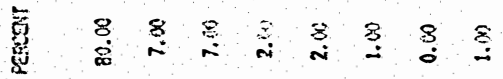

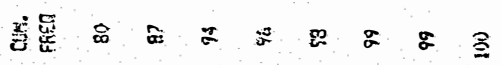

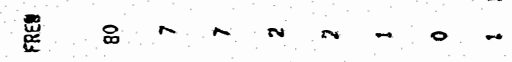

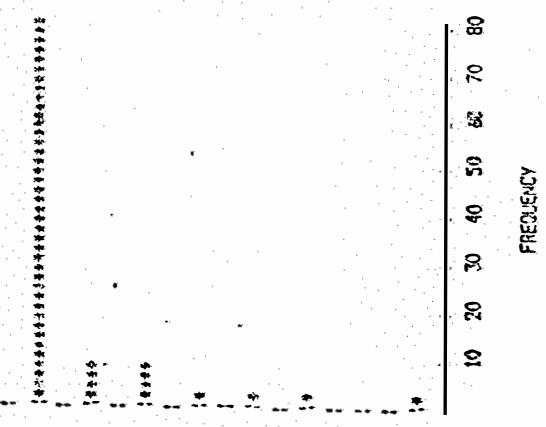

- 黄 马

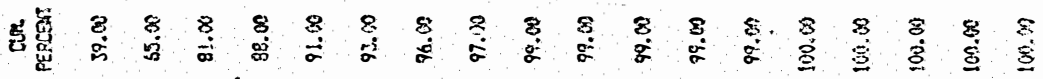

营

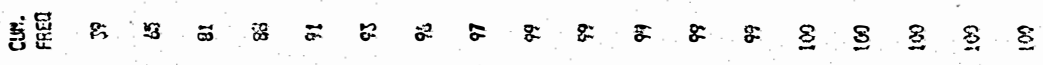

要 O

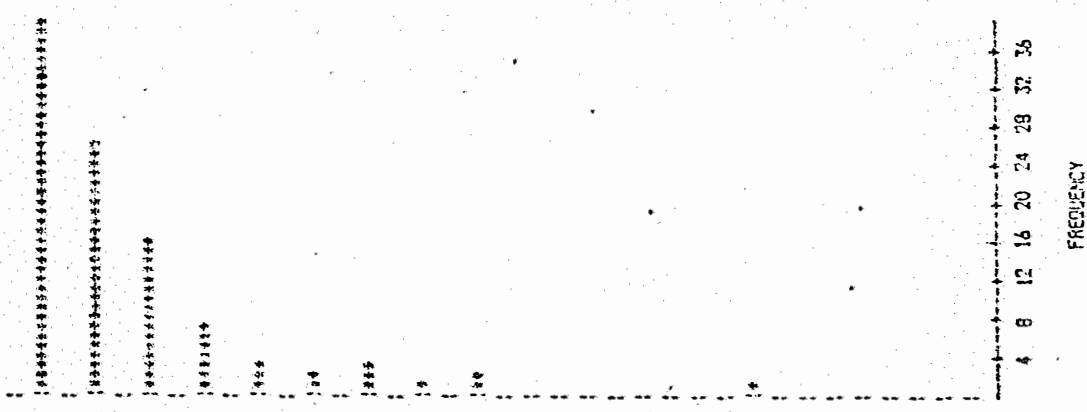

裹 g

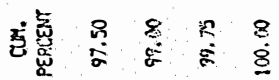

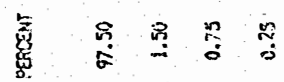

훌 욜 웅

最 $8 \circ-$

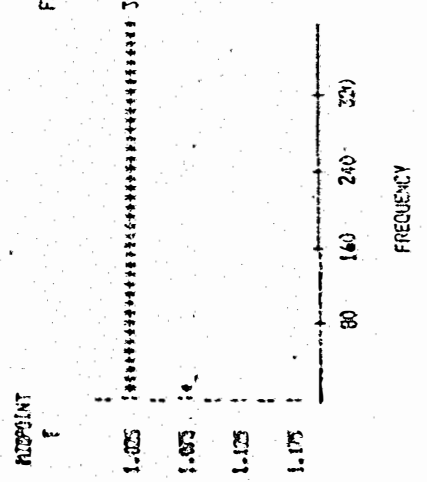




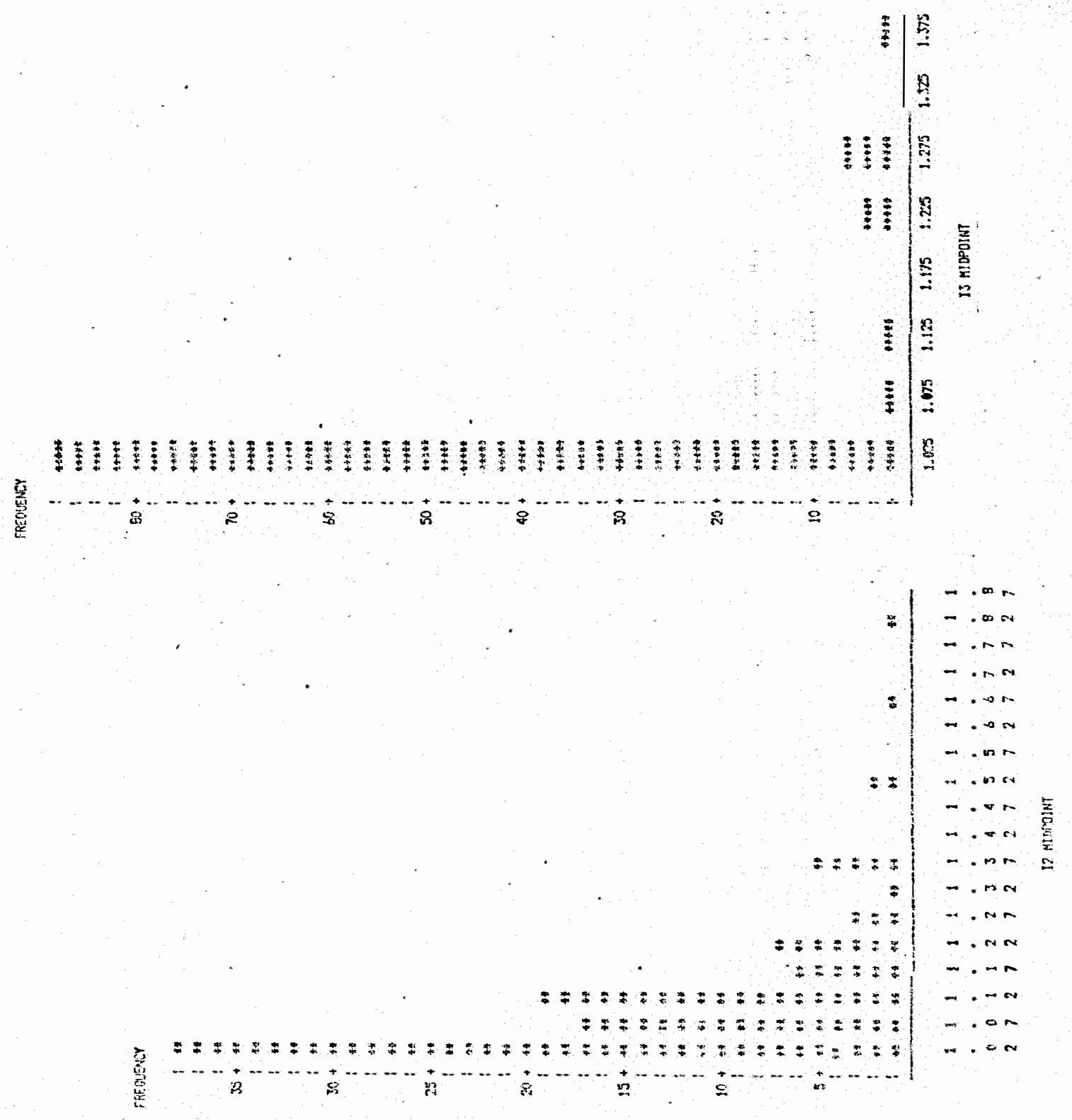



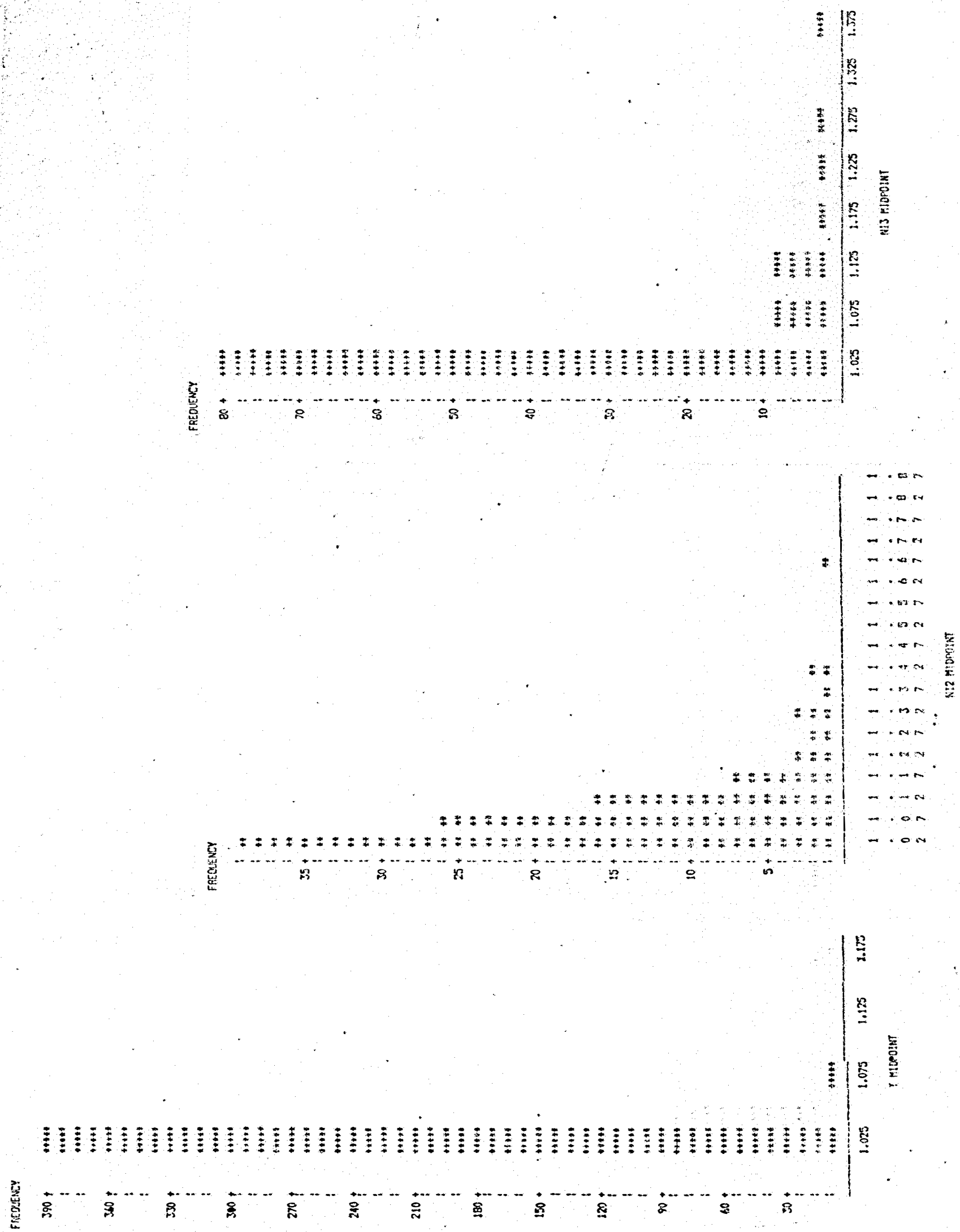
4.5 Fusăo de Protoplastos.

4.5.1 Fusăo de Protoplastos por tratamento com polie tilenoglicol.

A fusão de protoplastos de Humicola sp por tra tamento comi PEG foi ensaiada cono descrito no item 3.8 .1 e cu jos resultados são apresentados na tabela 28 . F́ preciso salien tar que os valores da frequência de fusăo de $10 \times 10^{-4}$ e 0,33 $\times 10^{-4}$ são colocados em dúvida pela reversão, da marca de auxotrofia, apresentada pelo mutante glu l com frequercias maio res que a de fusão, $61 \times 10^{-4}$ e $0,8 \times 10^{-4}$ respectivamente. Porém, deve-se destacar que as coionias revextentes apresenta ram crescimento residual com un tamanho de colonia muito peque no, sen chegar a esporular, enquarto as colonias dos possiveis produtos de fusão foram de tamanho notoriamente major cheganco a esporular: LAGUNA (2983) selecionou, com sticesso, nibridos interespecificos, produtos de fusão de leveduras auxotrópicas com crescimento residual, atravês do tamanho de colônia. para elucjar este assunto seria preciso transferir esses possiveis rodutos de fusão a MM sem estabilizacior osmótico e MC, realizando assin uma análise genética aplicando a técnica des crita por ROPER (1952).

As frequências de fusão obtidas no presente tra balho, $0,0033 \%$ e $0,1 \%$, estão dentro dos valores que rormalnen te sâo encontrados na literatura. Existem numerosos trabalhos, de diferentes pesquisadores, como os de KIRIMURA et álii (1986) que obtiveram com mutantes de A. niger frequênoias de fusão entre 2,0 e $6,3 \%$; ANNE \& PEBERDY (1976) em P. chrysogenum, 
P. patulum, P. roquefortii, A. nidulans, A. niger, $\underline{\text {. }}$. acremonium obtiveram frequencias que vão de 0,1 a $0,7 \%$; SILVI RA \& AZEVEDO (1987) em Metarhizium anisopliae foram de 0,0009\% a $0,044 \%$.

OLtras tentativas de fusão não foram bem sucedidas, por exemplo dos mutantes auxotróficos arg_I x Doador Morto; glu I x Doador Morto e Doador Morto x Doador Morto. Pro vávelmente, nestes casos, a fusão não chegou a produzir-se cisvido ao tratamento térmico a que foi submetido o Doador Morto. Como já foi discutido no item 4.2 .3 a temperatura á qual se inativam os protoplastos é critica. O tratamento térmico a que Foram submeticios os protoplastos de Humicola sp (62oC durante $10 \mathrm{min.}$ tavez não foi o mais adequado devido á näo fusão guan do participaram células do Doador Morto. Provávolnente se prom duz alguma alteração de membrana nestes protoplastos impedindo a formaça de recombinantes como afirmado por BALrz e MATSUSHI. MA (1983). Dado que BALTZ \& MATSUSHIMA (1983) obtiveram mais recombinantes, de streptomyces, que oCHI (2982) pela obtençäo do Doador Morto etravés de um tratamento térmico mais prolongado mas a temperatura mais baixa, é razoável. pensar que taivez poderia, para o caso do Humicola sp, resolver-se esse in conveniente com um tratamiento térmico desse tipo.

Tabela 28. Fusão de protoplastos de mutantes auxotroficos de humicola $\mathrm{ap}$ por tratamento com polietilenogljcol.

\begin{tabular}{|c|c|c|c|}
\hline & Linhagens & Fenótipos & $\begin{array}{l}\text { Frequência de } \\
\text { fusäo }\left(10^{-4}\right)\end{array}$ \\
\hline 1 & $\arg l \times g l u$ & $\arg _{-}^{-} \times g l u^{-}$ & 10 \\
\hline 2 & $\arg I \times g I u I$ & $\arg g^{-} \times g l u^{-}$ & 0,33 \\
\hline
\end{tabular}




\subsubsection{Fusão de Protoplastos por Eletrofusão.}

Com todas as soluções ensaiadas, apresentadas nas tabelas 29 e 30 , foram realizados testes de eletrofusão. De acordo com os resultados de regeneração e das observaçöes, da eletrofusão, realizadas através do acompanhamento microscópico na câmara de microsliaes, chegou-se á conclusão que a solução para eletrofusão (item 3.3 .25 ) com Sorbitol $0.8 \mathrm{M} \mathrm{pH}$ 7,0 era a mais adequada e que os parâmetros mais ericientes para o fusionamento de protoplastos de Humicola sp eram: Ali nhamento $60 \mu \mathrm{seg} ., 60 \mathrm{~V}$; Compressão $20 \mu \mathrm{seg} ., 60 \mathrm{~V}$; Fusão 60 useg.,45 V, aplicando 2 pulsos com um campo alternado com fre quência de $1 \mathrm{MHz}$. Para se assegurar a fusão, WEBER et alii (1981) mantiveram a câmara de fusão em repouso durante 30 min. a $28 \% \mathrm{C}$ enquanto SCHNETTLER \& ZIMMERMANN (1985) a mantém a 20259C. Deve-se destacar que no caso do Humicola sp o aparecimen to de células fundidas foi observado a partir de 30 minutos após realizada a fusão, mantendo a câmara a temperatura ambiente (25-300C). Ás células fundidas (fig.19) feram observadas âṕós 40 minutos de realizada a fusão. É preciso destacar que, mesmo tendo adaptado umasolução adequada para efetuar a eletro fusaõ de protoplastos de Humicola sp e determinado os parâmetros da mesma, os tiabalhos desenvolvidos neste sentido são apenas preliminares e muito mais deve ser estudado para se alcançar o máximo de eficiência desta poderosa técnica de fusão. Por exemplo, HALFMAN et alii (1983) utilizaram pronase para melhorar a fusão, enquanto HALFMANN et alii (1982) utilizaram uma solução de Sorbitol $1,4 \mathrm{M}$ e PEG 40\%. Porém, este último re 
curso foi ensaiado adicionando na solução de Sorbitol $0,8 \mathrm{M}$ PEG nas concentrações de 40 e $20 \%$ não sendo eficiente dado que os protoplastos de Humícola sp não migraram para os eletrodos,. como o faziam sem adição do PEG, durante a fase de alinhamento.

Tabela 29. Sobrevivência e Regeneração de Protoplastos de Humicola sp após tratamento com Sacarose $0,8 \overline{\mathrm{MH}} 5, \overline{6}$ e 7,0 , após 9 dias de incubação.

\begin{tabular}{|c|c|c|c|c|}
\hline $\begin{array}{c}\text { Tempo } \\
\text { (horas) }\end{array}$ & & $\begin{array}{l}\text { Controle MgSO } \\
0,5 \mathrm{M} \text { pH5, } 6\end{array}$ & $\begin{array}{c}\text { Sacarose } 0,8 \mathrm{M} \\
\mathrm{pH} 5,6\end{array}$ & $\begin{array}{l}\text { Sacarose } \\
0,8 M \mathrm{MH}, 0\end{array}$ \\
\hline zero & $\begin{array}{l}\text { Contagem } \\
\text { Aspecto }\end{array}$ & $\begin{array}{l}3 \times 10^{5} \\
\text { Normal }\end{array}$ & $\begin{array}{l}3 \times 10^{5} \\
\text { Normal }\end{array}$ & $\begin{array}{l}3 \times 10^{5} \\
\text { Nornal }\end{array}$ \\
\hline 5,00 & $\begin{array}{l}\text { Contagem } \\
\text { Sobrevivência } \\
\text { Aspecto } \\
\text { Regeneração }\end{array}$ & $\begin{array}{l}1,1 \times 10^{5} \\
36,66 \% \\
\text { Normal } \\
0,33 \%\end{array}$ & $\begin{array}{l}3,1 \times 10^{5} \\
100 \% \\
\text { Normal. } \\
0,13 \%\end{array}$ & $\begin{array}{l}2,9 \times 10^{5} \\
96,66 \% \\
\text { Normal } \\
0,16 \%\end{array}$ \\
\hline
\end{tabular}

Obs.: Os protoplastos foram mantidos nessas soluções durante 5,00 horas e logo semeados para regeneração em MC $\mathrm{MgS}_{4}$ $0,25 \mathrm{M}$. 
Tabela 30. Regeneração de Protoplastos de Humicola sp após tratamento com solução para eletrofusão de Sorbitol $0,8 \mathrm{M}$ e $1,2 \mathrm{M} \mathrm{pH} 7,0$, após 9 dias de incu. bação.

\begin{tabular}{c|c|c|c|} 
Tempo & Controle & Sorbitol $0,8 M$ & Sorbitol $1,2 M$ \\
& MgSo $0,5 M$ & & \\
\hline 1.00 & $1,0 \%$ & $0,52 \%$ & $0,21 \%$ \\
2.00 & $0,69 \%$ & $0,43 \%$ & $0,14 \%$ \\
3.00 & $0,64 \%$ & $0,38 \%$ & $0,15 \%$ \\
4.00 & $0,38 \%$ & $0,25 \%$ & $0,16 \%$
\end{tabular}

Solução para eletrofusão (item 3.3 .25 )

Obs.: Os protoplastos foram mantidos nessas soluções duran te os tempos especificados a partir dos quais foi ti rada uma amostra e semeada para regeneração en $M C$ $\mathrm{MgSO}_{4} 0,25 \mathrm{M}$. 
Fig. 19. Protoplastos de Humicola sp fundidos por eletrofusão. 


\section{CONCLUSÕES}

Dos resultados obtidos podem ser tiradas as se guintes conclusões:

1. A revelação do halo de degradação da celulose em Humicola sp apresentou-se mais clara em meio de extrato de malte e citrato de sódio $10 \mathrm{mM}$ incubado por 5 dias a 42 oc $e$ com aplicação de choque térmico.

2. A visualização de halo de degradação de celulose ao redor das colônias comprova a capacidade do Humícola sp em exportar celulases.

3. Tratamentos enzimáticos, do micélio, por períodos de tempo longos são adequados para estudos de regeneração, bioquímicos ou mesmo para fusão de produtos genéticos já está-veis, uma vez que são obtidos números considerávelmente maio res de protoplastos. Para a obtenção demutantes ou estabilização de determinados produtos genéticos é apropriado um tratamento por um período mais curto de tempo, pois obtem-se uma maior proporção de protoplastos uninucleados. 
4. O esquema de seleção em placa de variantes de maior produção celulolitica, demostrou ser eficiente perinitindo o isolamento de variantes de maior produção de enzimas celulo liticas.

5. A irradiação com luz UV foi um processo efetivo no incremento da variabilidade genética.

6. A transferência de material genético através da técnica de "doador morto" não foi bem sucedida, provávelmente pela não obtenção deste "doador" na forma mais adequada.

7. A solução mais eficiente para a eletrofusão foi aque la contendo sorbitol 0,8 M sendo que para completar a fusão celular é importante deixar a camara de fusão em repouso, an tes de diluir e semear a suspensão. 
ABDEL-KADER, M.I.A.; A.I.I. ABDEL-HAFEZ \& S.I.I. ABDEL-HAFEZ . Composition of the fungal flora of syrian soils: 2. Celluiase-decomposing flingi. Micopathologia 81: 167-172, 1983 .

AHN, J.S. \& M.Y. PACK. Improvement of protoplast regeneration by growing yeast cells hypertonically. ApplEnviron. Microbiol. 49(6):1550-1552, 1985.

ALEXIEVA, P.; A. DZHEROVA; D. NIKOLAVA \& P. SHEREMETSKA. Pro duction of a highly active mutant: producer of acid protease by treatment with gamma-rays. AC ta Microbiol. Bulg 6:59-63. Apud Biol. Abstr. $\underline{72}(11), 1980$.

ALIKHANIAN, S.I.. Induced mutagenese in the selection of microorganisms. Adv.Appl.Microb. (4):1-50, 1962 . 
ANDRES, I. \& J.F. PEBERDY. The production of invertase in Aspergillus niduㅣㅡㅡㅁㅗ with reference to the erfects of glucose and sucrose. Microbios $10: 15-23,1974 \mathrm{a}$

ANDRES, I. \& J.F. PEBERDY. Release of invertase from Aspergillus nidulans by the action of lytic enzymesand invertase secretion by regenerating protoplasts. Microbios $\quad \underline{11}: 15-20,1974 \mathrm{~b}$.

ANNE, J.; H. EYSSEN \& P. DE SOMER. Somatic hibridization of Penicillium roquefortii and p, chrysogenum after protoplast fusion. Nature, London 262: $719-721,1976$.

ANNE, J. \& J.F. PEBERDY. Conditions for induced fusion of fun gal protoplasts in polyethylene glycol solutions. Archives of Microbiology 105:201-205, 1975 .

ANNE, J. \& J.F. PEBERDY. Induced fusion of fungal protoplasts following treatment with polyethylene glycol. J. Gen. Microbiol. $92: 413-417,1976$.

ANTUNES, L.A.F.; M.P.CEREDA \& R. CAMARGO. Decomposição simula da da palha de arroz e obtenção de microrganismos celuloliticos. Arq. Biol. Tecnoi. 29(3): 533-543, 1986 . 
ARAUJO, E.F.; E.G. BARROS: R.A. CALDAS \& D.O. SILVA. B-GIUcosidase activity of the thermophilic and cellu lolytic fungus Humicola sp. Biotechnol. Lett. 5: $781-784, \quad 1983$.

ARAUJO, A. \& J.D SOUZA. Characterization of cellulolytic enzyme components from Aspergillus terreus and its mutant. J. Ferment. Technol. $64(5): 463-467$, 1986.

AZEVEDO, J.L.. Melhoramento genético de fungos através da fu são de protoplastos. In: 30. ENCONTRO DE GENETICISTAS PAULISTAS, 3., 1983. Anais. p.17-22. Es: 1333

AZEVEDO, J.L. \& S.O.P. COsTA. Exercfcios práticos de genética. São Paulo, Companhia Editorial Nacional, 288p . 1973.

AZEVEDO, J.L.; E.P. SANTANA \& R. BONATELLI Jr.. Resistance and mitotic instability to chloroneb $\cdots$ and

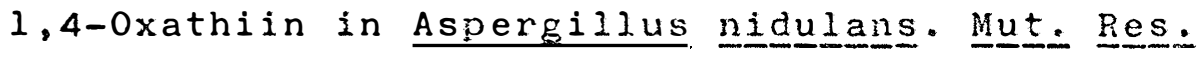

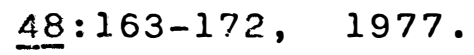

BACHMANN, B.J. \& D.M. BONNER. Protoplasts from Neurospora crassa. J. Bacteriol. 78:550-556, 1959 . 
BALTZ, R.H. \& P. MATSUSHIMA. Advances in protoplast fusion in streptomyces. Exper. Suppl. (Basel) 46: $143-148,1983$.

BARACHO, I. R. \& S. FERKÃO. Utilização da luz ultravioleta no melhoramento de Aspergillus niger para produ çåo de ácidocftrico. Rev. Mjcrobiol. $\underline{1} \underline{4}(2): 84-89, \quad 1983$.

BASTIDE, M.; E. HADIBI; D. SCHEIBER; M. HIEGEUILLE; C. VERMEII \& J.M. BASTIDE. Modelités de liberation des pro toplastes de Saccharomyces cerevis microscopie életronique a balayage. Ann. Microbiol. (Inst. Pasteur) 130A:419-433, 1979.

BECAK, W \&J. PAULETTE. Técnicas de citologia e histologia.Vol. 2. Rio Janeiro, Livros técnicos e cientificos, 1976. $305 \mathrm{p}$.

BENITEZ, T.; S. RAMOS \& I. GARCIA-ACHA. Protoplast from Trichodermaviridae. Arch. Microbiol. 103:199-203.

BENITEZ, T.; T.G. VILLA \& I. GARCIA-ACHA. Chemical and structü ral diffexences in mycelial and regeneration walls of Trichoderma viridae. Arch. Microbiol. $\underline{1} \underline{\underline{5}}: 277-285, \quad 1975$. 
BERG, H.; K. AUGSTEN; E. BAUER; W. FORSTER; H. JACOB; P. MUH LIG \& H. HEBER. 664-possibilities of cell fu sion and transformation by electrostimulation. Bioelectrochemistry and Bioenergetics $12: 119-133, \quad 1984$.

BERG, B. \& A. HOFSIEN. The ultraestructure of the fungus Trichoderma viridae and investigation of its growth on cellulose. J.Appl. Bacteriol. 4I: $395-400, \quad 1976$.

BERTOLDI, M. \& C.E. CATEN. Isolation and haploidization of heterozygous diploid strains in a species of Humicola. $\quad$ I. Gen. Microbiol. 91:63-73, 1975 .

BROWN, J.A.; S.A. COLLIN \& T.M. WOOD. Enhanced enzyme production by the cellulolytic fungus penicillium pinophilum,mutant strain NTG III/6. 프므yㅡㄹ Microb. Technol. $9: 176-180, \quad 1987 \mathrm{a}$.

BROWN, J.A.; D.J. FALCONER \& $2 . M$. WOOD. Isolation and proper ties of mutants of the fungus penicilitum pingophilum with enhanced cellulase and $\beta$-glucosidase production. Enzzyme Mícrob. Technol. 9: $169-175, \quad 1987 \mathrm{~b}$. 
BUSCHL, R.; H. RINGSDORF \& U EIMMERMANN Electric field-in duced fusion of large liposomes from natural and polimerizable lipids . FEBS Lett. $\underline{15} 0: 38-42, \quad 1982$.

CANEVASCINI, G.; M.R. COUDRAY; J.P.REY;R.J.G. SOUTHGATE \& H. MEIER. Induction and catabolite repression of cellulase synthesis in the thermophilic fungus Sporotrichum termophile. J. Gen. Microbiol. $110: 291-303,1979$.

CARPENTER, P.L.. Microbiologia. México, Interamericana S.À., 1969. $421 \mathrm{p}$.

CHAPMAN, C.M. \& J.R. LOEWENBERG. Supplement to plant physio log.y $\quad 57: 70,1976$.

CHAVES, V.M.G.. Caracteristicas fisiolegicas de um fungo ter mórilo isolado de compostagem e propriedades de seu complexo celulase. Viçosa, 1982. 60p.i(Mes trado - Universidade Federal de Viçosa).

COSSAR, D. \& G. CANEVASCINI, Cellulase enzyme production during continuous culture growth of sporotrichum (Chrysosporium) thermophile. Appl. Microbiol. Biotechnol. $24: 306-310, \quad 1986$. 
CosTA, M.B. \& N. Van UDEN. Use of 2-Deoxyglucose in the selective isolation of mutants of Trichoderma reese i with enhanced $\beta$-glucosidase production. Biotechnnol. Bíoㅡㅁㅡ. 22:2429-2432, 1980 .

COUGHLAN, M.P.. The properties of fungal and bacterial celu lases with comment on their production and application. Biotechnology and Genetic Engineering Reviews, 3:39-109, 1985.

COUTTS, A.D. \& R.E. SMITH. Factors influencing production of cellulases by sporotrichum thermophile. App모. Environ. Micrubiol. 31:819-825, 1976 .

DAVIS, B.. Factors influencing protoplast isolation. In: PEBERDY, J.F. \& L. FERENCZY. Fungal protoplasts. Marcel Dekker Inc., 1985, p.45-72.

DEMAIN, A.L.. The marriage of genetics and industrial microbio logy after a long engagement, a bright future. In: VANEK,Z.; Z. HOSTALEK \& J. CUDLING, Eds. Genetics of Industríal Microorganisms. Amsterdam, Elsevier Publishing Co., 1973. Vol.l, p.19-32.

DEMAIN, A.L.. Theoretical and applied aspects of enzyme regu lation and biosynthesis in microbial cells. Biotechnol. Bioeng. Symposium (3):21-32, 1972 . 
DEORAY, E.D. \& V.P. BHIDE. In vitro cellulose decomposition by fungi from the rhizosphere of grapevine. J. Univi. Poona. Sci. Technol. $0: 133-140$, Apuad. Biol. Abstr. 75(6), 1981 .

DEUTCH, C.E. \& J.M. PARRY. Sphaeroplast formation in yeast during the transition from exponential phase to stationary phase. J. Gen. Microbiol. $0,59-$ 80: $259-263,1974$.

DE VRIES, O.M.H. \& J.G.H. WESSELS. Chemical analysis of cell wall regeneration and reversion of protoplasta from Schizophyilum comune. Arch. Microbjol. 102: $209-218,1975$.

DHAR; M.M. \& A.W. KHAN. Formation of antibiotics. Nature (London) $\underline{233}: 182,1971$.

EDDY, A.A. \& D.H. WILLIAMSON. A method Oṫ isolating protoplasts from yeast. Nature (London) 179:1252-1253, 1957.

TMERSON, S. \& M.R. EMERSON. Froduction, reproduction and rever sion of protoplast like structures in the osmotic strains of Neurospora crassa. Proc. Nat. Acad. Sci.: (Washington) 44:668-671, 1958 . 
ERIKSSON, K.E. \& S.G. HAinP. Regulation of endo-l,4-B-gIucana se production in sporotrichum pulverulentum. Cur. J. Biochem. $90: 183-190,1978$.

EYSSEN, H.. Formation of protoplasts of Penicillium chrysogenum and some other filamentous fungi. Agricultura $25: 21-44,1977$.

FARKAS V.; I. LABUDOVA; S. BAUER \& L. FERENCZY. Preparation of mutants of Trichoderma viridae with increased production of cellulase. Folia Microbiol. 26:129-132, 1981 .

FARKAS, V. \& A. SVOBODA. Kinetics of beta-glucan and chitin formation by cells and protoplasts of the yeast Saccharomyces cerevisiae. Curr. Microbiol. $4: 99-104, \quad 1980$.

FERENCZY, L.. Microbial protoplast fusion. In: GLOWER, S. W. \& D.A. HOPWOOD.Ed.. Genetics_as_a tool in microbiology. Cambridge, Cambridge University Press, 1981, p.l-34.

FODOR,K.; E. DEMIRI \& L. ALFOLDI. Polyethylene glycol-induced fusion of heat-inactivated and living proto plast of Bacillus megaterium. Appli. Environ. Microbiol. $135(1): 68-70,1978$. 
FUJII, M. \& M. SHIMIZU. Synergism of endoenzyme and exoenzyme on hydrolysis of soluble cellulose derivati ves. Biotechnol. Bioeng. $28: 878-882,1986$.

FUNAGUMA, T.; H. TSUJI \& A. HARA. Purification and some pro perties of celulose $1,4-\beta$-cellobiosidase from a strain of Penicillium sp. J. Ferment. Technol. $\underline{6} \underline{4}(1): 77-80,1986$.

FURTADO, J.S.. Basidial cytology of exidia nucleata.

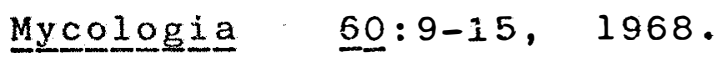

GABRIEI, M.. Formation and regeneration of protoplasts in the mold Rhizopus nigricans. Folia Microbiol. $13: 231-234,1968$.

GHOSH, V.X.; T.K. GHOSE \& K.S. GOPALKRISHNAN. Improvement of T. reesei strain through mutation and selective screening techniques, Biotechnol. Bioeng. 24:241-243, 1982 .

GIBSON, R.K.. Studies on protoplasts of Aspergillus nidulans and their regeneration. Nottingham, 1973 . (Ph.D.- University of Nottingham).

GONG, C.S. \& G.T. TSAO. Cellulase and biosynthesis regulation. In: PERLMAN, D. Annuals Reports on Fermentation Processes. Academic Press, New York, 1979. $3: 111-140$. 
GOTTSCHALK, G.; W.H. HAMILTON; W. HARDER; A. de LEEUW; O.M. NEIJSSEL \& C. RATLEDGE. Microbial physiology and biotechnological innovation in the EEC coun tries, Portugal and Spain. Report No. XII-5868-EN, DG-XII Concertion Unit for Biotechnology in Europe, Brusels.

GOULDEN, S.A. \& F.W. CHATTAWAY. End product control of acetohydroxy acid synthetase by valine in penicillium

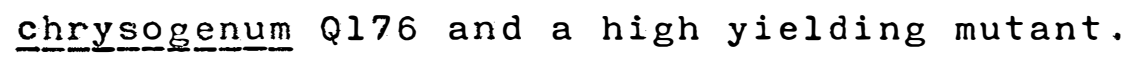
J. Gen. Microbiol. 59:111, 1969 .

GRAJEK, W.. Comparative studies on the production of cellulases by thermophilic fungi in submerged and so lid-state fermentation. Appl. Microbiol. Biotechnol. 2 $26: 126-129,1987$.

GRIGOROV, I.; P. ALEKSIEVA; A. DJEROVA; P. SHEREMETSKA \& B. TCHORBANOV. Selection of Gamma-ray mutants from a strain of Humicola lutea 72 , producing acid proteases. Eur. J. Appl. Microbiol. Biotechnol. $17: 355-357,1983$.

GUPTA, J.K.; C.K. SHIRKOT \& S. DHAWAN. Isolation and muta tion of cellulolytic fungi. Acta Microbiㅡ으를 Acad. Sci. Hung. 2 요:31-36, 1981 . 
HALFMANN, H.J.; C.C. EMEIS \& U. ZIMMERMANN. Electro-fusion of haploid Saccharomyces yeast cells of identi-

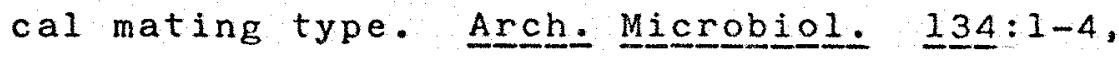
1983 .

HALFMANN, H.J.; W. ROCKEN; C.C. ENEIS \& U. ZIMMERMANN. Trans fer of mitochondrial function into a cytoplasmic respiratory deficient mutant of Saccharomyces yeast by electro-fusion. Current Genetics. $6: 25-28,1982$.

HALLIVELL, G. \& M. GRIFFIN. The nature and mode of action of the cellulolytic component $C_{1}$ of Trichoderma k으믐iㄹ on native cellulose. Biochem. J. $1 \underline{3} \underline{5}: 587-594,1973$.

HAMLIN, P.F.; R.E. BRADSHAW; F.M. MELLON; C.M. SANTIAGO; J.M. WILSON; \& J.F. peberdy: Efficient protoplast isolation from fungi using commercial enzymes. Enzyme Microb. Tecㅡ므요. 3:321-325, 1981 .

HARGER, C.C.; J.B. PASSOS \& D.O. SILVA. Is the constitutive intracellular $\beta-D-g l u c o s i d a s e$ of Humicola $\mathrm{sp}$ responsable for glycosylation? Arq. Bi으를 Tecnn으르 29:47, 1986 . 
HARRINGTON, J.; L. KIRVAN \& M.R. STUART. Heat toleranse of thermophilic and thermotolerart fungi in compos ted conifer bark. J. Life Sci. R. Dublin Soc. 1,99:105. Apud. Biol. Abstr. 르(7), 1979.

HAVELKOVA, M. \& P. MENSIK. The ultrastructures of the cells and the protoplasts of Lipomyces lipofer.Antoni. ne van Leenwenhoek, 35. Supplement: Yeast Symposiun Bl5-Bl6.

HAYASHIDA, S. \& K. MO. Production and characteristics of avi cel desintegrating endoglucanase from a protease-negative Humicola grisea var. thermoidea mutant. Appl. Environ. Microb. 51 (5):1041-1046, 1986.

HAYASHIDA, S. \& H. YOSHIOKA. Production and purification of thermostable cellulases from Humicola isolens YH-8. Agric. Biol. Chem. 44:1721-1728, 1980.

HOPWOOD, D.A. \& M.J. MERRICK. Genetics of Antibiotic produc tion. Bacteriological Review 4I:595-635, 1977.

HOUSSET, P.; M. NAGY \& J. SCHNENCKE. Frotoplasts of Schizzcsaccharomyces pombe. An improved method for their preparation and the study of their guani-

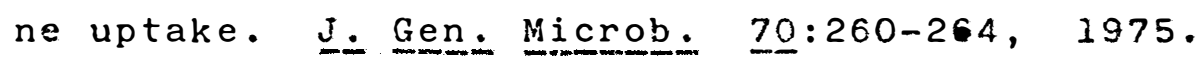


HULME, M.A. \& D.W. STRANKS. Induction and the regulation of production of cellulase by fungi. Nature $2 \underline{26}: 469-470,1970$.

HULME, M.A. \& D.W. STRANKS. Regulation of cellulase production by Myrothecium versucaria grown on no-cellulase substrates. J. Gen. Microbiol. 60:145-155, 1971.

JACOB, H.E.; W. FORSTER; H. BERG \& H. WEBER. Vth. Inter. Symp. on Bioelectrochem Bioenerg., Weimar, Poster, 1979 .

JACOB, F. \& J.MONOD. Genetic regulatory mechanisms in the synthesis of proteins. I. MoI. Bi으. $3: 318-356$, 1961.

JAIN, M.K.; K.K. KAPOOR \& M.M. MISHRA. Cellulase activity degradation of cellulose and lignin and humus formation by thermephilic fungi. Trans. Br. Mycol. Soc. 73:85-89, 1979 .

KAO, K.N. \& M.R. MICHAYLUKE. A method for high-frecuency intergeneric fusion of plant protopiasts. Planta (Berl.) 115:355-367, 1974. 
KEVEI, F. \& J.F. PEBERDY. Interespecific hibridization between Aspergillus nidulans and Aspergillus rugulosus by fusion of somatic protoplasts. J. Gen. Microbiol. 102:255-262, 1984 .

KEVEI, F \& J.F. PEBERDY . Further studies on protoplast flu sion and interespecific hybridization within the Aspergillus nidulans group. J. Gen. Microb$130: 2229-2236, \quad 1984$.

KIRIMURA,K.; S.P. LEE; S. KAWABE \& S. USAMI. Haplojd recombi nants formed as sectors in the intraspecific fusants of Aspergillus niger producing citric acid. I. Ferment. Technol. 65:557-562, 1987.

KIRIMURA, K.; T. YAGUCHI \& S. USAMI. Intraspecific protoplast fusion of citric acid-producing strains of Aspergilius niger. J.Fermen. Technol. $64(6): 473-479, \quad 1986$

KLEYN, J.G. LE.F. WEIZLER." The microbiology of spent mushroom compost and its dust. Can. J. Microbiol. 2그:748-753, 1981 .

LAGUNA, S.E.. Estabilidade genética e beterose em hibridos interespecificos de leveduras. Piracicaba, 1983. 168p. Hestrado- Escola Superior de Agricultura "Luiz de Queiroz"/USF). 
LEE, G.M.; C.Y. CHOI; J.M. PARK \& M.H. HAN. The properties Of inmobilized whole cell of Humicola spp. with rifamycin oxidase activity. Biotechnol. Lett. 6: $143-148, \quad 1984$.

LEE, Y.H. \& L.T. FAN. Properties and mode of action of ceilu 1ase. Adv. Biochem. Eng. 18:101-129, 1980.

LUENGO, J.M.; G. REVILLA; M.J. LOPEZ; J.R.VILLANUEVA \& J.F. MARTIN. Penicilion production by mutants of Penicillium chrysogenum resistant to polyene macrolide antibiotics. Biotechnol. Lett. $1: 233-238, \quad 1979$.

LYSEK, H.; O. FASSATIOVA; N.C. PINEDA \& N.L. HERNANDEZ. OVIcidal fungi in soils of Cuba. Folia Parasitol. (Praha) 29:265-270, 1982 .

MACEDO, J.M.B.. Avaliação do comportanento de Humicola sp. com vistas ao melhoramento genético para produ ção de celulaşes. Rio de janeiro, UERJ, 1986, $90 \mathrm{p}$..

MACEDO, J.M.B. \& J.L. de AZEVEDO. Utilização do método simplex na otimização de parâmetros importantes na ob tenção de protoplastos em Humicola nigricans. In:REUNIÃO ANUAL DE GENẼTICA DE MICRORGANISMOS . $12 ., 1985$ 
MANDELS, M.. Microbial sources of celluiase. Biotechnol. Bioeng. Symp. $5: 81-105,1975$.

MANDELS, M.. Growth and cellulase production by Trichoderma. In: BAILEY M., T.M. ENERI \& M.IINKO. Sympo- sium on the enzymatic hydrolysis of cellulose. Helsinki, The Finnish National Fund for Research and Development (SITRA), 1975. p.8I-109.

MANDELS, M.; R. ANDREOTTI, \& C. ROCHE. Measurement of saccha rifying cellulase. Biotechnol. Bioeng. Symposium $6: 21-23,1976$.

MANDELS, M \& E.T. REESE. Induction of cellulase in fungi by cellobiose. I. Bacteriol. $\quad$ 29:816-826, 1960 .

MANDELS, M.; J. WEBER \& R. PARIZEK. Enhanced cellulase produc tion by amutant of Trichoderma viridae. Appl.

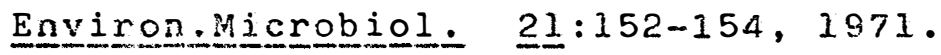

MATSUSHIMA, P. \& R.H. BAITZ. Protoplast fusion. In: DEMAIN, A.L. \& N.A. SOLOMON. Manual of Industrial Mi crobiology and Biotechnology. Washington, Ane rican Society for Microbology, 1986. 466p. 
MAZEN, M,B.; A.H. MOUBASHER \& A.I.I. ABDEL-HAEEZ. SOME eCOLO gical studies on Jordanian soil tungi:2. Cellu lose decomposing fungi. Nat. Monspel. Rev.

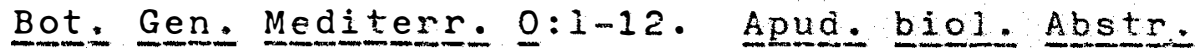
$72(3), \quad 3.980$.

MELLON, R.E.. Studies on microbic heredity. I. Observations on a primitive form of sexuality (zygospora formation) in the colon typhoid group. Bacteriolosy 10:481-501, 1925 .

MONTI, R. \& J.a. JORGE. Cellulase production in Humicola, sp. R.P.17. Arg. Biol. Tecnol. 29:42, 2.986.

MONTI, R. \& J.A. JORGE. Furitication of a extracellular xyla nase from Humjcola grisea var. thenmoidea R.P. 17. Arq. Biol. Iecnol. 30(1):103, $198 \%$.

MONTI, R.; H.F. TERENZI \& J.A. JORGE. Regulação de celulases

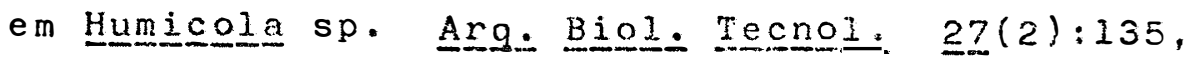
2984 .

MORAES, M.L.T.; R.A. PRADE \& H.F. TERENZI. Characterization of the B-glucosidase system of the cellulolytic fungus Humicola sp. Arg. Biol. Tecnol. $28(1): 57,1985$. 
MORINAGA, T.; S. KANDA \& R. NOMI. Lipase production of a new thermophilic fungus, Humicola lanuginosa var. catenulata. J.Ferm. Tecnhnol. 64(5):451-453.. 1986 .

MOREISON, J.; U. MC CARTHY \& A.P. MC HALE. Cellulase production by palaromyces emersonid CBS 814.70 and a mutant UV7 during growth on cellulose, lacto se and glucose containing media. Enzyme Microb. Technol. 9:422-425, 1987 .

MORRISON, K.B. \& R.C. RIGHELATO. The relationship between hyphal branching, specific growth rate and colony radial growth rate in Penicillium chrysogenum. J. Gen. Microbiol. EI:517, 1974 .

WONTENECOURT, B.S. \& D.E. EVEIEIGH. Semiquantitative plate assay for detarmination of celulase production by Trichoderma viridae. Appl. Environ. Microbiol.

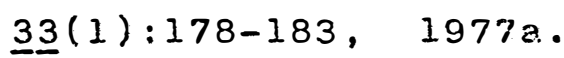

MONTENECOURT, B.S. \& D.E. EVELEIGH. Preparation of mutants of Trichoderma reesei with enhanced cellulase pro duction. Appl. Environ. Microbiol. 34:777-782, $1977 \mathrm{~b}$. 
MONTENECOURT, B.S. \& D.E. EVELEIGH. Hypercellulolytic mutants and their role in saccharification. In: SHUSTER W. Ed. Second Annual Fuels from Biomass. Ney York, 1978. p.613-625.

MONTENECOURT, B.S.; S.D. NHLAPO; H. TRIMIÑO-VAZQUEZ; S. CUSKEY D.H.J. SCHAMHART \& D.E. EVELEIGH. Regulatory controls in relation to overproduction of fungal. cellulases. In: Hollaender, A.. Trends in the biology of fermentations for fuels and chemicals. Easic life sciences $18: 33-53,1980$.

MONTENECOURT, B.S.; D.H.J.SCHAMHART \& D.E. EVEIEIGH. MEChanisms controlling the synthesis of the Trichoderma reesei celiulase system. In: BERKELEY, E.C.W.; G.W. GOODAY \& D.C.EIWOOD(ed.). Microbiol polysaccharides and polysaccharases. New York, Academic Press, 1979. p.327-337.

MOWE, G.; B. KING \& S.J. SENN. Tropic responses of fungi to wood volatiles. J. Gen. Microbicl. 129:779-784, 1983.

MULLER, R.. Contribution to the problem of protoplast fusion.

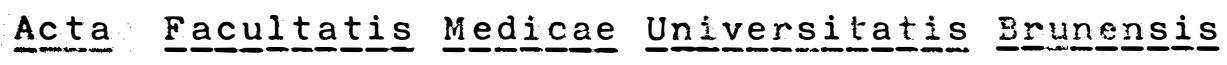
37: $39-41, \quad 1970$. 
NECAS, O.. Cell wall synthesis in yeast protoplasts. Bacteriol. Rev. 35:149-170, 1971 .

NEVALAINEN, K.M.H.; E. T. PALVA \& M.J. BAILEY. A hIgh cellula se producing mutant strain of Trichoderma reesei. Enzyme Microbiol. Techrol. 2:59-60, 1980.

NIKOLOVA, D.; A. DZHEROVA; M. GEORGIEVA; P. ALEXIEVA \& P.SHERE METSKA. characteristics of an enzyme preparation containing acid protease from Humicola lutea strain 120-8:1. Purification by gel chromatogra phy. Acta Microbiol. Bulg 6:64-69. Apud Biol. Abstr. $\quad \underline{7} \underline{2}(10), 1980$.

NISIZAWA, T. \& H. SUZUKI. Catabolite repression of cellulase fermentation in Trichoderma viridae. J. Biochem. $71: 999-1007,1972$.

OCHI, K.. Protoplasts fusion permits high-frequency transfer of a streptomyces determinant which mediates actinomycin synthesis. J. Bacteriol. $150: 592-597, \quad 1982$.

OGAWA, K.; J.A. BROWN \& T.M. WOOD. Intraespecific hybridization of Trichoderma reesei QM9414 by protoplast fusion using colour mutants. Enzyme Microb. Technol. 9:229-232, 1987 . 
OGUNDERO, V.W.. Amylase ard cellulase activities of thermophi lic fungi calising aeterioration of tobacco products in Nigeria. Mycopathologia 69:13i-136, 1979 .

OGUNDERO, V.V.. Degradation of nigeriar palm products by ther mophilic fungi. Trans. Br. Mycol. Soc.

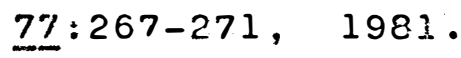

PEBERDY, J.F.. Fungal prtoplasts: Isolation, reversion and fusion. an․ Rev. Microbiol. 33:21-39, 1.979.

PEBERDY, J.F.. Mycolytic enzynes. In: PEBERDY, J.F. \& L. FERENCZY. Fungal protoplasts: their use in phy. siology, biochemystry and genetics. New York, Marcel Dekker Inc., 1985a. p.31-44.

PEBERDY, J.F.. Tusão de protoplastos em fungos. In: AZEVEDO, J.L. Genetica de Microrganismos em biotecnoloEia e engenharia genética. Piracicaba, FEALQ, $3.985 b \cdot p \cdot 61-66$.

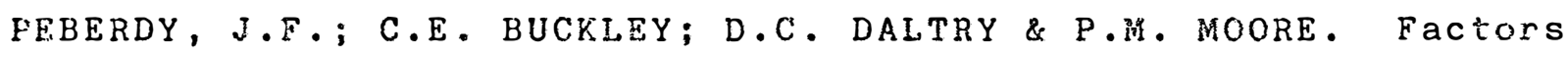
affecting protoplast release in some filamentous fungi. Trans. Br. Mycol. Soc. 67:23-26, 1976. 
PEBERDY, J.F. \& L. FERENCZY. Furgal Protoplasts. New York, Marcel Dekker, 1985. 354p.

PEBERDY, J.F. \& R.K. GIBSON. Regeneration of Aspergillus nidulans protoplasts. J. Gen. Microb. $\underline{69}: 325-330,1971$.

PELCZAR, H.; R.REID \& E.C.S. CHAN. Microbiologia.VOI.I. São Paulo, No Graw Hill, 1980. 566p..

PERALTA, R.M. \& J.A. JORGE. GIucosidase enzymes in Humjcola grisea var. thermoidea R.P. 17. Arq. Biol. Tecnol. $\quad 30(1): 102, \quad 1987$.

PERLMAN, D. \& I.C.C. HALL. Actinophage as a selective agent for increasing antibiotic production. Abstract of $172 n d$. Meeting American Chemical Society, 34, 1976 .

PETTERSON, G; E.B. COWLING \& J. PORATH. Studies on celluloly tic enzymes. Biochem. Biophys. Acta 67:l-8, 1963.

PICATAGGIO,S.K.; D.H.J.SCHAMHART; ; B.S. MONTENECOURT \& D.E. EVELEIGH. Sphaeroplast formation na regereration in Trichoderma reesei. Eur. J. Appl. Microbiol. Biotechnol. 17:121-128, 1983 . 
FOHL, H.A.. dielectrophoresis. Cambridge, Cambridge Univer sity Press, 1978. $252 \mathrm{p}$.

POLIZELI, M.L.T.M. \& H.F. TERENZI. Study of the B-glucosidase activity of the fungus Humicola sp. Arq. Biol. Tecnol. 29:44, 1986

PONTECORVO, G.;J.A. ROPER; L.M.HEMMONS; K.D. MC DONALD \& A.W.

J, BUFTON. The genetics of Aspergilius nidulans Advances in Genetics $5: 141-238,1953$.

RAUTELA, G. S. \& E.B. COWLING. Simple cultural tests for rela tive cellulalytic activity of fungi. Appl. Environ. Microbiol. 14:892-898, 1966 .

REESE, E.T.. History of the cellulase program at the U.S. Army Natick Development Center. Biotechnol. Bioeng. Symp. $\quad 6: 9-20, \quad 1976$.

REESE, E.T.; R.G.H. SIV \& H.S. IEVINSON. The biological degra dation of soluble celiulose derivatives and its relationship to the mechanism of cellulose hidrolise. J. Bacterjol. 59:485-497, 1950.

ROBINOW, C.F. \& C.E. CATEN. Mitose in Aspergillus nidulans.

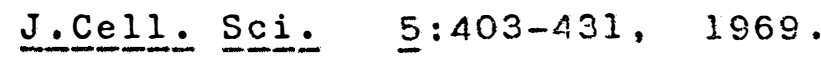

RODRIGUEZ, C. E. Caracterização citogenētica e bioquímica do fungo celuio Iitico Humicola sp. Piracicaba, 1987. 152 p. (Mestra.. dc - Escola Superior de Agricultura "Luiz de Queiroz"/Usp). 
ROMANNELLI, R.A.; C.M. HOUSTON \& S.M. BARNETT. StUdies on thermophilic cellulolytic fungi. Appl. Environ. Microbio1. $\quad 30: 276-281, \quad 1975$.

ROPER, J.A.. Production of heterozygons diploids in filamentous fungi. Experientia $8: 14-15,1952$.

RYU, D.D.Y. \& M. MANDELS. CeIlulases: biosynthesis and appli cations. Enzyme Microbiol. Technol. 2:91-102, 1980.

SAGARA, Y.. Studies on prtoplasts of Gectrichum candidum: mechanisms of formation of protoplasts and their physical and morphological properties. Tokushi ma J.Exp. Med.. 16:57-69, 1969.

SANTOS, A.L. \& J.I. DE AZEVEDO. Resistência do fungo entomopa togênico Metarrhizium anisopliae em relaçăo a três fungicidas. Rev. Microbiol. $13(3): 272-278$, 1982 .

SAUNDERS, V.A. \& J.R. SAUNDERS. Microbial genetics applieo to biotechnology. London, Croom Helm, 1987. $422 \mathrm{p}$ 
SCHNETTLER, R. \& U. ZIMMERMANN. Influence of the composition of the fusion medium on the yield of electrofu sed yeast hybrias. FEMS Microbiol. Lett. $27: 195-198, \quad 1985$.

SCHWENCKE, J.; N. MAGANA-SCHEWENCKE \& J. LAPORTE. Yeast protoplasts from stationary and starved cells: Prepa ration, ultraestructure and vacuolar development. Ann. Microbiol. 128 A: $3-18,1977$.

SENDA, M.; I. TAKEDA; S. ABE \& T. NAKAMURA. PIAnt and CeII. Physi요므. 20:1441-1443, 1979.

SEONG, B.L.; H.J. SON; T.I. MHEEN; Y.H. PARK \& M.H. HAN. ENZY matic oxidation of rifamycins by a microorga nisms of the genus Humicola. J. Ferm. Technol. $6 \underline{3}(6): 515-522, \quad 1985$.

SERMONTI, G.. Genetics of antibiotic-producing microorganisms John Wiley \& Sons Ltd., London, 1969, 398p.

SHAKER, H.M.; M.A. FARID \& A.I. EL-DIHANY. Optimization of the composition of the nutrient medium for cellulase ard protein biosynthesis by thermophilic Aspergilius fumigatus NRC 272. Enzyme Microb- Technol. $6: 212-216, \quad 1984$. 
SHARMA, P.; S.PAJNI;N. DHILLON; D.V. VADEHARA \& D.K. DUBE. Limitations of the congo-red staining techniques for the detection of cellulolytic activi

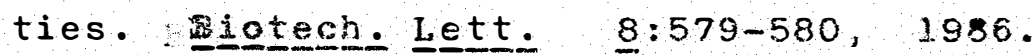

SHENOLIKAR, S. \& K.J. STEVENSON. Purifiction and partial characterization of a thiol proteinase from the thermophilic fungus Humicola lanuginosa. Biochem. J. 205:147-152, 1982 .

SILVA, J.C. \& J.L. DE AZEVEDO. Utilization of gamma-rays in the selection of Aspergillus niger for acia production. Rev. Bras. Genet. 1(1):41-5*, 1978 .

SILVEIRA, W.D.\& J.L.AZEVEDO. Protoplast fusion and genetic recombination in Metarhizium anisopliae. Enzyme Microb. Technol, 9:149-152, 1987 .

SMITH, W.E.. Observations indicating a sexual mode of repro duction in a common bacterium (Bacteroides funduliformis). J.Bacteriology $47: 417-418$, 1944 .

STEEL, R. \& J. TORRIE. Principles and procedures of statistics. Mícraw-Hill, New York, 1960, 473 p.

STEWART, J.C. e J.B.PARRY. Factors influencing the production of cellulases by Aspergillus fumigatus. J. Gen.

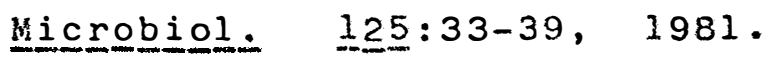


STREIBLOVA, E.. Surface structure of yeast protoplasts. J. Bacteriology $\quad 95: 700-707,1968$.

TAKAGI, M... Inhibition of celiulase by fermentation products. Biotechnol. Bioeng. 25(12):1506-1507, 1984.

TAKAGI, M.; S. ABE; S. SUZUKI; G.H. EMERT \& N. YATA. BIOCOnversion of cellulosic substances into energy, chemicals and microbial proteins. In:PROCEEDINGS OF THE BIOCONVERSION SYMPOSIUM, DEIhi, 1978. Proceedings. Delhi, Indian Inst. Tecnol., 1978. $551 \mathrm{p}$

TAMADA, M.; N. KSAI; M.KUMAKURA \& I. KAETSU, Periodical batch culture of the inmobilized growing fungi Sporotrichum cellulophilum producing cellulase in the nonwoven materials. Biotechnol. Bioeng. 28: $1227-1232,1986$.

TANAKA, Y.; N. MURATA \& H. KATO, 1979. Behavior of nuclei and chromosomes during ascus development in the matting between either rice-strain or weeping lovegrass-strain and ragi-strain of Pyricularia. Ann. Phytopath. Soc. Japan. Tokyo, 45: $182-191$.

TANSEY, M.R.. Agar difrusion assay of cellulolytic ability of thermophilic fungi. Archiv. fur Mikrobiol. 77:1-i1, 1971 .

TEATHER, R.H. \& P.J. WOOD. Use of congo red polysaccharide interactions in enumeration and characterization of cellulolytic bacteria from the bovine rumen. Appl. Environ. Microbiol. 43:777-780, 1982 
TOYAMA , H.; A. SHINMYO \& H. OKADA. Protoplast formation

from conidia of Trichoderma reesei by cell wall

-lytic enzymes of a strain of Trichoderma

viridae. J. Ferment. Technol. 64(1):409-411,

1983.

TOYAMA, H. ; K. YAMAGUCHI; A.SHINMYO \& H. OKADA. Protoplast fusion of Trichoderma reesei, using inmature coridia. Appl. Envirron. Microbiol. $4 \underline{7}: 363-368$, 1984.

TRIVEDI, L.S. \& K.K. RAO. Production of cellulolytic enzymes by Aspergillus fumigatus. Ind. Exp. Bi으르. $17: 671-674, \quad 1979$.

VIEIRA, E. \& R.A. PRADE. Production of cellulases and zylana ses: effect of catabolite repression on enzyme synthesis in Trichoderma reesei $Q M 9414$, Aspergillus phoenicis and Humicola nigricans. Arg. Biol. Tecnol. 29:43, 1986 .

VILLANUEVA, J.R. \& I. GARCIA ACHA. The phenomenon of regeneration in fungal protoplasts. Fev. Lat. Am. Microbiol. $\quad 14: 49-64,1972$.

WASE, D.a.J.; W. J. MC MANAMEY; S. RAYMAHASAY \& A.K. VAID. COM parison between cellulase production by Aspergillus fumigatus InI255091. Enzyme Microb. Technol. $\quad 2: 225-229,1985$. 
WASSERMAN, B.P.. Thermostable enzyme production. Food Technol. 38 : $78-98,1984$.

WEBER, H.; H. FORSTER; H. BERG \& H.E. JACOB. Parasexual hybridization of yeasts by electric field stiinulated fusion of protoplasts. Current Genetics. $4: 165-166,1981$.

WOOD, T.M.. Properties of ceilulolytic enzyme systems. In: CELlULASES: PRODUCTION, PROPERTIES AND APPLICA TIONS. 611, Galway, 1985. Meeting. Galway, M.P. Coughlian, 1985. p407-410.

XIMENES, E.F.F. \& C.R. FELIX. Isolation characterization of the intracellular and extracellular forms of

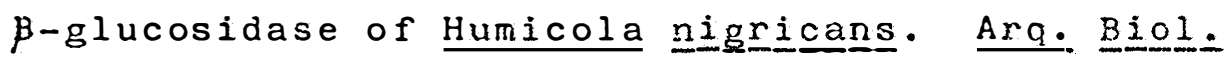
Tecriol. 29: 46,1986 .

YOSHIOKA, H.; S.I. ANRAKU \& S. HAYASHIDA. Production and purification of a novel type of carboxymethilcellulase from Humicola grisea var. thermoidea YH-78. Agric. Biol. Chem. 46:75-82, 1982 .

ZIMMERMANN, U.. Electric field- mediated fusion and related electrical phenomena. Biochem. Biophys. $694: 227-277, \quad 1982$. 
ZIMMERMANN, A.L.S. \& J.a. JORGE. Trehalase activity in

Humicola grisea var. thermoidea R.P. 17. Arq. Biol. Tecnol. $30(1): 102,1987$.

ZIMMERMANN, U. \& G. PILWAT. Electrical breakdown of cell mem branes. In: BIOPHYS, CONGR., 6, Kyoto, 1978. Abstract. Kyoto, 1978. p.140.

ZIMHERAANN, U. \& P. SCHEURICH. High frequency fusion of plant pro toplasts by electric fields. Planta 15 $1: 26-32$, 1981 .

ZIMMERMANN, U.; P. SCHEURICH; G. PILWAT \& R. BENZ. Zellen mit mani pulierten Funktionen. Nene Perspektiven fur zellbiologie, Medizin und Technik. Angew. Chem. 93:332-351, 1981 .

ZIMMERMANN, U.; I. VIENKEN \& P. SCHEURICH. Biphys. Struct. Mech. $6: 86,1980$.

ZIMMERMANN, U. \& I. VIENKEN. Electric field-induced cell-to -cell fusion. J. Membrane Biol. 67:165-182, 1982 . 